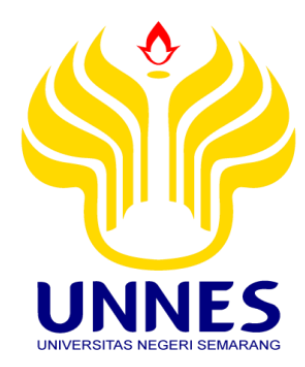

\title{
BENTUK PERTUNJUKAN KESENIAN BARONGAN \\ WAHYU BUDAYA DI DUKUH KARANG REJO \\ DESA LORAM KULON KECAMATAN JATI \\ KABUPATEN KUDUS
}

\author{
SKRIPSI \\ untuk memperoleh gelar Sarjana Pendidikan \\ Oleh \\ Nama : Abrilia Dwi Alfianingrum \\ NIM $\quad: 2501409128$ \\ Program Studi : Pendidikan Seni Tari \\ Jurusan $\quad$ : PSDTM
}

FAKULTAS BAHASA DAN SENI UNIVERSITAS NEGERI SEMARANG

2016 


\section{PERSETUJUAN PEMBIMBING}

Skripsi ini telah disetujui oleh pembimbing untuk diajukan ke Sidang Panitia Ujian Skripsi.

Semarang, 16 Juli 2016

Menyetujui,

Pembimbing I

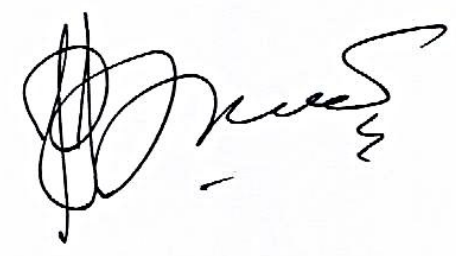

Moh. Hasan Bisri, M.Sn NIP. 196008171986012001
Pembimbing II

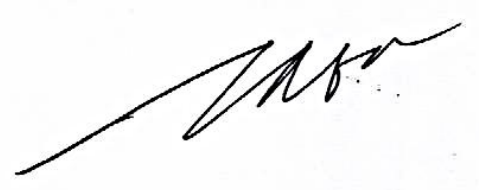

Joko Wiyoso, S. Kar, M. Hum NIP. 1962100401988031002

1 


\section{PENGESAHAN KELULUSAN}

Skripsi ini telah dipertahankan dihadapan sidang Panitia Ujian Skripsi Jurusan Pendidikan Sendratasik, Fakultas Bahasa dan Seni, Universitas Negeri Semarang

$$
\begin{array}{ll}
\text { Pada hari } & : \text { Selasa } \\
\text { Tanggal } & : 30 \text { Agustus } 2016
\end{array}
$$

Panitia Ujian Skripsi

Prof. Dr. M. Jazuli, M.Hum (NIP. 196107041988031003) Ketua

Abdul Rachman, S.Pd., M.Pd (NIP. 198001202006041002)

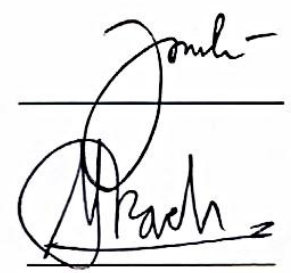
Sekretaris

Dra. Eny Kusumastuti., M.Pd (NIP. 196804101993032001) Penguji I

Moh. Hasan Bisri, S.Sn., M.Sn (NIP. 196601091998021001) Penguji II/Pembimbing I

Joko Wiyoso, S.Kar., M.Hum (NIP. 196210041988021002) Penguji III/Pembimbing II

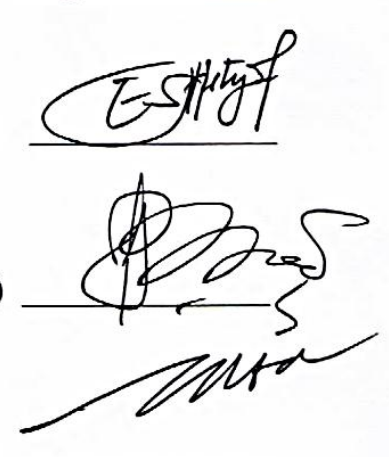
Prof. Dr. Agus Nury̆atin, M.Hum (196008031989011001)

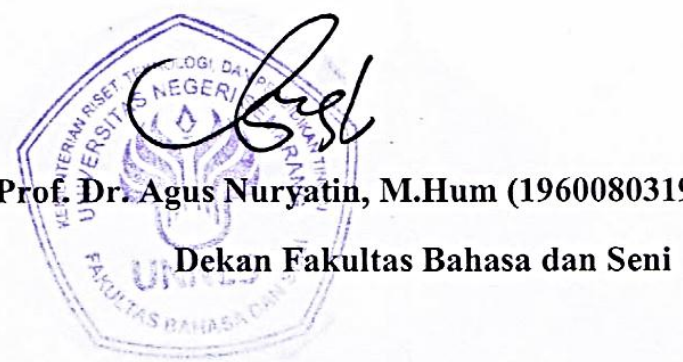


PERNYATAAN

Saya menyatakan bahwa yang tertulis di dalam skripsi ini benar-benar hasil karya saya sendiri, bukan jiplakan dari karya orang lain, baik sebagian atau seluruhnya. Pendapat atau temuan orang lain yang terdapat dalam skripsi ini dikutip berdasarkan kode etik ilmiah.

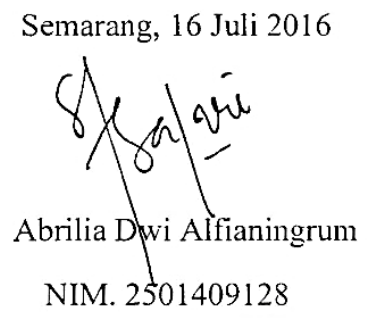

1 


\section{MOTTO DAN PERSEMBAHAN}

Motto:

1. Siapa yang mengerjakan kebaikan sebesar biji dzarah sekalipun, niscaya ia akan melihat balasannya (QS. Al-Zalzalah : 7)

2. Hidup adalah proses, Hidup Adalah Belajar, Tanpa ada batas umur, tanpa ada kata tua. Jatuh berdiri lagi, kalah mencoba lagi, gagal bangkit lagi.

3. Teruslah berkata baik dan memberi nasehat yang baik, walaupun orang tidak mengenalmu, cukuplah Allah mengenalmu lebih dari yang lain (Tausiyahku)

\section{Persembahan:}

Skripsi ini saya persembahkan untuk

1. Bapak dan Ibuku tercinta, Bapak Pelda Sutikdjo dan Ibu Sofiatun

2. Kakakku Muhammad Alifin

3. Adikku Satria Bian Toro

4. Sahabat seperjuangan dan orang-orang terkasih. 


\section{PRAKATA}

Alhamdulillah, Puji syukur atas kehadirat Allah SWT yang Maha Pengasih lagi Maha Penyayang. Berkat Rahmat, Hidayah dan Inayah-Nya, akhirnya saya dapat menyelesaikan skripsi untuk memenuhi sebagian persyaratan guna memperoleh gelar sarjana. Peneliti dalam menyusun skripsi ini memperoleh banyak bantuan dan bimbingan serta pengalaman dari berbagai pihak. Pada kesempatan ini peneliti mengucapkan banyak terimakasih kepada yang terhormat:

1. Prof. Dr. Fathur Rokhman, M.Hum., Rektor Universitas Negeri Semarang yang telah memberikan kesempatan kuliah di UNNES.

2. Prof. Dr. Agus Nuryatin, M.Hum., Dekan Fakultas Bahasa dan Seni yang telah memberikan ijin untuk melaksanakan penelitian.

3. Dr. Udi Utomo., M.Si Ketua Jurusan Pendidikan Sendratasik yang telah memberikan bantuan dan kemudahan dalam penyusunan skripsi ini.

4. Moh. Hasan Bisri, M.Sn., Dosen Pembimbing I dan Joko Wiyoso, S. Kar, M.Hum Dosen Pembimbing II yang telah banyak membimbing dan meluangkan waktunya untuk memberikan arahan serta saran-saran selama penyusunan skripsi.

5. Segenap Dosen Jurusan Pendidikan Seni Drama Tari dan Musik yang telah banyak memberi bekal pengetahuan dan ketrampilan selama belajar di Universitas Negeri Semarang.

6. Sukadi selaku pimpinan dan pengelola Grup Kesenian Barongan Wahyu Budaya di Dukuh Karang Rejo, Desa Loram Kulon, Kecamatan Jati Kabupaten Kudus. 
7. Pemain Kesenian Barongan Wahyu Budaya yang telah memberikan bantuan kepada penulis dalam memberikan informasi jadwal pementasan dan pengambilan data.

8. Teman-teman seni tari dan semua pihak yang tidak dapat penulis sebutkan satupersatu yang telah membantu dan memberikan semangat serta dukungan dalam mengerjakan skripsi.

Semarang, 16 Juli 2016

Abrilia Dwi Alfianingrum

NIM. 2501409128 


\section{SARI}

Alfianingrum, Abrilia Dwi. 2016. Bentuk Pertunjukan kesenian Barongan Wahyu Budaya Di Dukuh Karang Rejo, Loram Kulon Kecamatan Jati Kabupaten Kudus. Jurusan Sendratasik, Fakultas Bahasa dan seni, Universitas Negeri Semarang. Pembimbing I : Moh. Hasan Bisri, M.Sn. Pembimbing II: Joko Wiyoso, S. Kar, M.Hum.

\section{Kata kunci: Bentuk Pertunjukan Barongan Kudus}

Barongan Wahyu Budaya merupakan salah satu dari beberapa grup kesenian Ketoprak dan Barongan yang berasal dari Desa Loram Kulon. Dibentuk pada tahun 1995 oleh Bapak Sukadi yang menjadi ketua Grup Kesenian Ketoprak dan Barongan Wahyu Budaya. Permasalahan yang diteliti dalam penelitian ini yaitu: bagaimana Bentuk Pertunjukan Kesenian Barongan Wahyu Budaya di Desa Loram Kulon Kecamatan Jati Kabupaten Kudus. Penelitian difokuskan pada setiap urutan penyajian kesenian Barongan Wahyu Budaya.

Metode penelitian yang digunakan dalam penelitian ini adalah metode kualitatif dengan teknik pengumpulan data yang meliputi: observasi, teknik wawancara dan teknik dokumentasi. Teknik analisis data yang digunakan dalam penelitian ini meliputi reduksi data, penyajian data dan penarikan kesimpulan.

Hasil penelitian mengungkapkan bahwa Kesenian Barongan Wahyu Budaya merupakan pelestarian dari kesenian Barongan peninggalan pemimpin Desa Loram terdahulu yang digunakan sebagai media penyebaran Agama Islam di kota Kudus. Hasil pembahasan mengacu pada elemen-elemen pertunjukan yang meliputi: 1) Ragam gerak antara lain gedrug, klebatan sampur, tepisan, klepatan, pancalan, ngaklak, caplokan, dekeman, dan glundungan. 2) Pelaku yaitu penari barong, Penthul, Bondet, penari Kuda Lumping. 3) Iringan menggunakan instrumen musik kendang, slompret, kenong, kempul, bonang, gong. 4) Tata rias wajah menggunakan rias prengesan untuk pemeran Penthul, sedangkan untuk Barongan menggunakan topeng. 5) Tata rias busana Barongan menggunakan topeng yang dilengkapi dengan kain loreng berwarna hitam putih, sedangkan Penthul menggunakan iket, sumping, kace, baju hem, sabuk bara-bara, jarik, sampur dan celana panji. 6) Properti topeng, kuda kepang, pecut atau cambuk, keris, kerincingan. 7) Pola lantai hanya melingkar dan garis lurus. 8) Tempat pertunjukan berada di halaman terbuka. 9) Penonton dari semua kalangan. 10) Urutan penyajian meliputi adegan pra tontonan, adegan inti dan arak-arakan. Kemudian juga pada kegiatan arak-arakan menuju rumah warga yang memiliki fungsi ekonomi bagi para pemain.

Saran dari penelitian ini adalah lebih dikembangkan lagi kesenian Barongan yang sudah ada dengan mengenalkannya kepada masyarakat luas agar generasi penerus dapat mengetahui bahwa Kota Kudus memiliki sejarah kesenian yang patut dibanggakan juga dilestarikan. 


\section{DAFTAR ISI}

\section{Halaman}

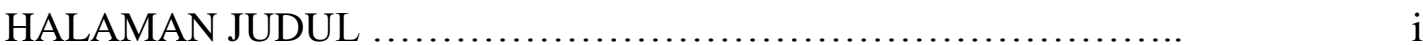

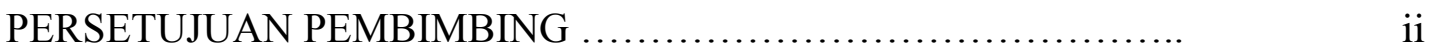

PENGESAHAN KELULUSAN ................................... iii

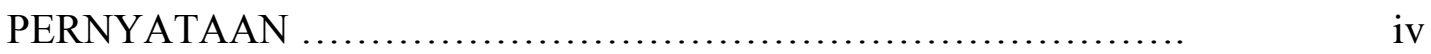

MOTTO DAN PERSEMBAHAN $\ldots \ldots \ldots \ldots \ldots \ldots \ldots \ldots \ldots \ldots \ldots \ldots \ldots . . \ldots \ldots$

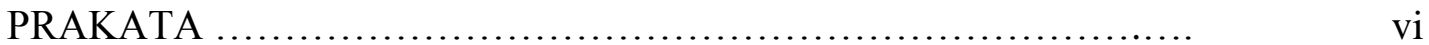

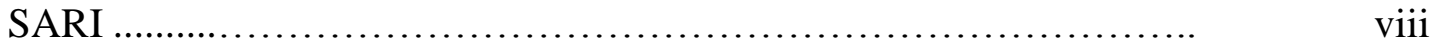

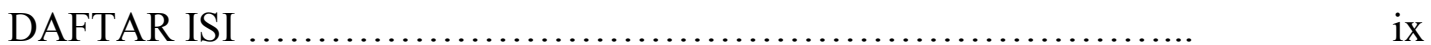

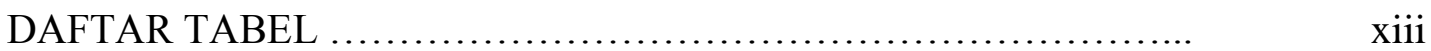

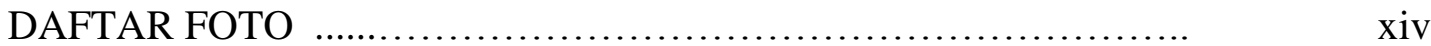

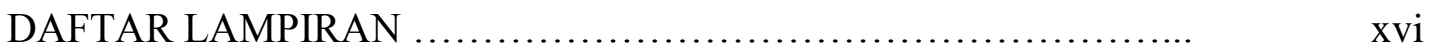

\section{BAB I PENDAHULUAN}

1.1 Latar Belakang .................................................

1.2 Rumusan Masalah ................................................ 5

1.3 Tujuan Penelitian .............................................. 6

1.4 Manfaat Penelitian ............................................ 6

1.5 Sistematika Skripsi ......................................... 7

\section{BAB II TINJAUAN PUSTAKA DAN LANDASAN TEORETIS}

2.1 Tinjauan Pustaka ................................................ 9

2.2 Landasan Teoretis .................................................. 
2.2.1 Kesenian .................................................

2.2.2 Kesenian Tradisional ..........................................

2.2.3 Kesenian Tradisional Kerakyatan ...............................

2.2.4 Bentuk Pertunjukan .......................................... 16

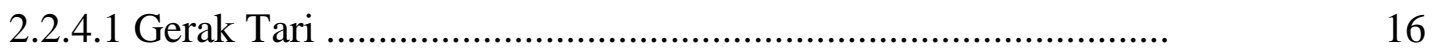

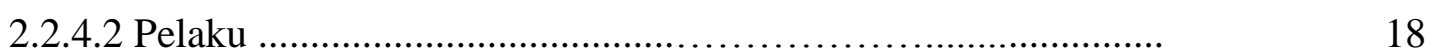

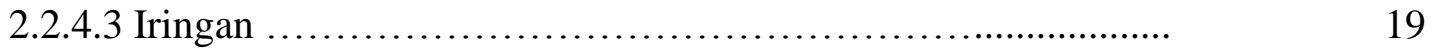

2.2.4.4 Tata Rias dan Busana ............................................ 21

2.2.4.5 Properti ........................................................ 21

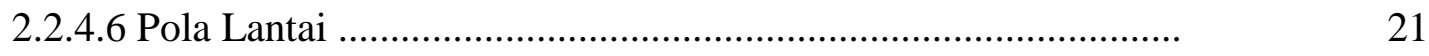

2.2.4.7 Tempat dan Waktu Pertunjukan ................................................ 22

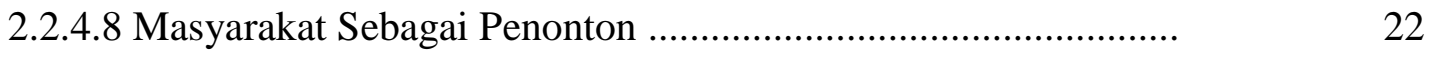

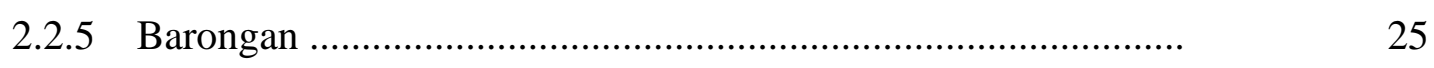

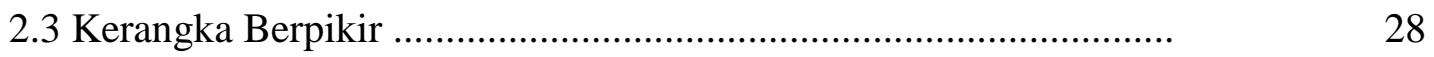

\section{BAB III METODE PENELITIAN}

3.1 Pendekatan Penelitian ........................................... 30

3.2 Lokasi dan Sasaran Penelitian .................................. 32

3.2.1 Lokasi Penelitian ........................................... $\quad 32$

3.2.2 Sasaran Penelitian ............................................ 33

3.3 Teknik Pengumpulan Data .................................... 33

3.3.1 Observasi ..................................................

3.3.2 Wawancara ................................................... 
3.3.3 Dokumentasi ............................................. 36

3.4 Teknik Keabsahan Data ................................. 37

3.5 Teknik Analisi Data ....................................... 38

\section{BAB IV HASIL DAN PEMBAHASAN}

4.1 Gambaran Umum Lokasi Penelitian ........................................ 40

4.1.1 Lokasi dan Keadaan Geografis Desa Loram Kulon ................... $\quad 40$

4.1.2 Kependudukan .............................................................. 42

4.1.3 Mata Pencaharian ................................................................

4.1.4 Kehidupan Keagamaan .................................................. 44

4.1.5 Pendidikan ................................................................... 45

4.2 Potensi Kesenian dan Budaya di Desa Loram Kulon ................. 46

4.2.1 Kesenian Terbang Papat ...................................................... 46

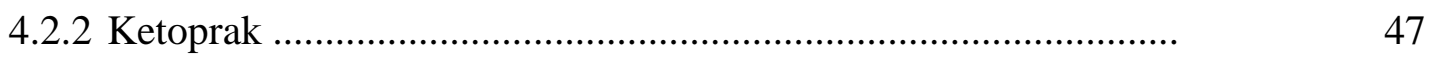

4.2.3 Tari Kretek .................................................................... 47

4.2.4 Kuda Lumping dan Barongan ............................................. 47

4.2.5 Gapura Masjid Wali .......................................................... 49

4.2.6 Tradisi Sego Kepel ..........................................................

4.2.7 Ampyang Maulid ........................................................... 50

4.2.8 Tradisi Kirab Pengantin ..................................................... $\quad 50$

4.3 Kesenian Barongan di Desa Loram Kulon ................................ $\quad 50$ 
4.4 Bentuk Pertunjukan Kesenian Barongan Wahyu Budaya ................ 56

4.4.1 Gerak ........................................................................... 57

4.4.1 Gerakan Pawang (Penthul) ...................................................... $\quad 57$

4.4.2 Gerakan Barongan .............................................................. 62

4.4.2 Pelaku (Penari) ...........................................................................

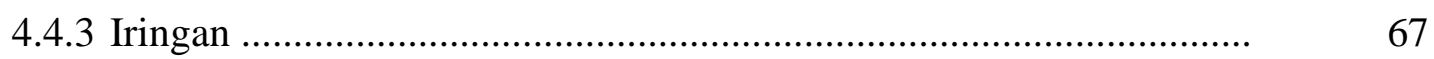

4.4.4 Tata Rias dan Busana .................................................................

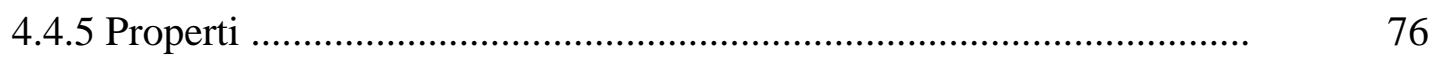

4.4.6 Pola Lantai ............................................................................ 83

4.4.7 Tempat dan Waktu Pertunjukan ................................................ 87

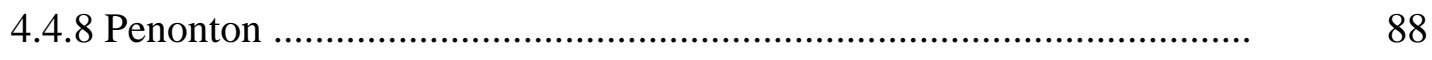

4.5 Urutan Penyajian Pertunjukan Barongan Wahyu Budaya ................. $\quad 89$

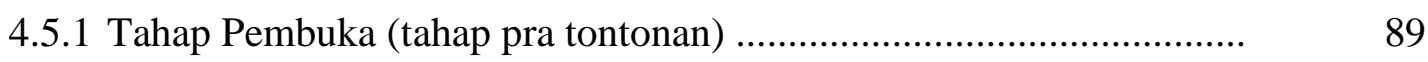

4.5.2 Tahap Inti ...................................................................... 92

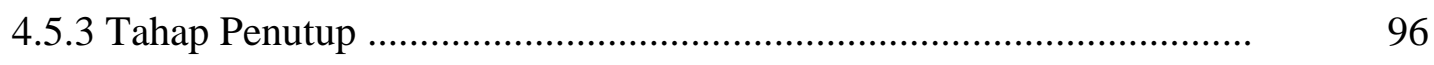

4.5.4 Arak-arakan Barongan Wahyu Budaya ........................................ $\quad 98$

\section{BAB V PENUTUP}

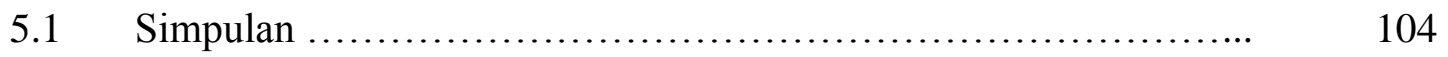

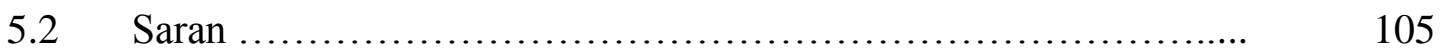

DAFTAR PUSTAKA …......................................................... 107

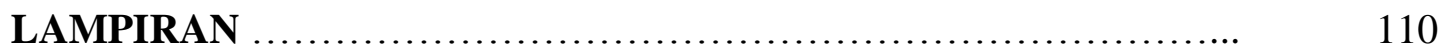




\section{DAFTAR TABEL}

Tabel

Halaman

4.1 Keadaan Penduduk Desa Loram Kulon ........................... 42

4.2 Data Mata Pencaharian Desa Loram Kulom ..........................

4.3 Data Pemeluk Agama Desa Loram Kulon ...................... 44

4.4 Data Jumlah penduduk Desa Loram Kulon berdasarkan Pendidikan .. $\quad 45$ 


\section{DAFTAR FOTO}

Foto

Halaman

4.1 Peta Desa Loram Kulon

4.2 Wawancara dengan Bapak Karmin (Pawang Barong)

4.3 Bapak Sukadi (Ketua Grup) dan Bapak Karmin (Pawang Barong) .....

4.4 Gedrug

4.5 Klebatan Sampur

4.6 Tepisan

4.7 Klepatan

4.8 Pancalan

62

4.9 Ngaklak

4.10 Caplokan

64

4.11 Ndekem

65

4.12 Glundungan

66

4.13 Pembarong Utama

4.14 Tata Rias dan Busana

4.15 Bentuk Barongan 1

4.16 Bentuk Barongan 2

4.17 Topeng Bondet.

4.18 Kuda Kepang

4.19 Pecut 


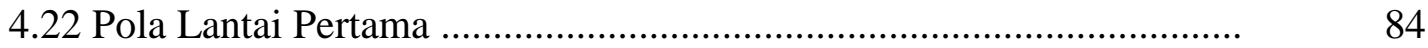

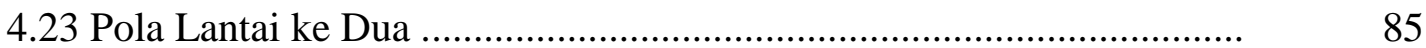

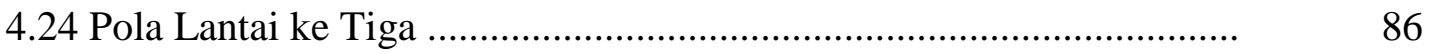

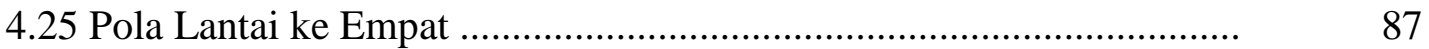

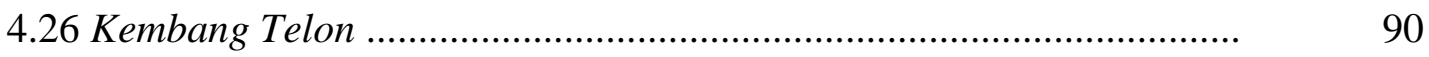

4.27 Pawang memasuki arena pertunjukan ....................................................

4.28 Barongan ditundukkan oleh Penthul ................................................. $\quad 95$

4.29 Barongan menghirup asap kemenyan ……………………….......... 96

4.30 Kesenian Kuda Lumping ............................................................... 


\section{DAFTAR LAMPIRAN}

\section{Lampiran}

Halaman

1. Keputusan Penetapan Dosen Pembimbing Skrispsi

111

2. Surat Izin Penelitian .................................................................... 112

3. Pernyataan Bukti Penelitian .......................................................... 113

4. Instrumen Penelitian ................................................................. 114

5. Data Informan ....................................................... 116 


\section{BAB I}

\section{PENDAHULUAN}

\subsection{Latar Belakang}

Jawa Tengah merupakan sebuah provinsi Indonesia yang terletak di bagian tengah Pulau Jawa, terdiri atas 29 kabupaten dan 6 kota. Jawa Tengah memiliki keanekaragaman budaya dan adat istiadat yang saling berbeda satu sama lain. Kebudayaan merupakan hasil cipta, rasa serta karsa manusia dalam penuhi kebutuhan hidupnya yang kompleks yang meliputi pengetahuan, kepercayaan, seni, susila, hukum kebiasaan serta tiap-tiap kecakapan, serta rutinitas (lahiya.com.2016).

Kabupaten Kudus termasuk kabupaten terkecil di provinsi Jawa Tengah dengan luas wilayah 42.516 Ha. Kota Kudus berada di jalur pantai utara laut Jawa Tengah yang menjadi jalan utama darat antara Jakarta dan Surabaya. Dahulu Kota Kudus bernama Kota Tajug. Masyarakat Kudus hidup dari bertani, buruh pabrik, membuat batu bata, menangkap ikan, dan berdagang. Jiwa dan semangat wirausaha masyarakat diakui ulet, semboyan jigang (ngaji dagang) yang dimiliki masyarakat mengungkapkan di mana di samping menjalankan usaha ekonomi juga mengutamakan mencari ilmu. Kudus memiliki beberapa potensi yang dapat dikembangkan, salah satunya adalah dalam hal seni dan budaya. Seni pertunjukan Barongan merupakan salah satu bentuk kesenian tradisional yang ada di Kudus dan diwarnai oleh corak kebudayaan masyarakat pendukungnya. 
Kesenian adalah bagian dari kebudayaan. Seni tari adalah salah satu bagian dan kesenian. Arti seni tari adalah keindahan gerak anggota-anggota badan manusia yang bergerak, berirama dan berjiwa atau dapat diberi arti bahwa seni tari adalah keindahan bentuk anggota badan manusia yang bergerak, berirama dan berjiwa yang harmonis (Bagong Kussudiardja, 2000:11). Kesenian tradisional adalah kesenian yang lahir karena adanya dorongan emosi atas dasar pandangan hidup dan kepentingan masyarakat pendukungnya secara turun temurun. Konsep seni yang berkembang di tengah masyarakat terkait dengan persoalan ekspresi, indah, hiburan, komunikasi, keterampilan, kerapian, kehalusan dan kebersihan (Jazuli, 2008:46).

Kota Kudus, tepatnya di Dukuh Karang Rejo, Loram Kulon Kecamatan Jati ada beberapa grup kesenian Barongan yang sampai saat ini masih sering dipertunjukkan, salah satunya adalah grup Ketoprak dan Barongan Wahyu Budaya. Kesenian Barongan merupakan bentuk kesenian yang disajikan sebagai sarana pemenuh kebutuhan hiburan yang dimainkan oleh dua orang penari laki-laki, satu berperan sebagai kepala barong (ndas) dan satunya lagi berperan sebagai ekor barong (buntut). Bentuk Barongan Kudus mengadopsi tekstur tubuh macan muria. Macan muria adalah harimau khas daerah pegunungan muria yang berbentuk agak kecil memanjang (hampir mirip seekor kucing namun agak besar) dengan motif loreng tipis memanjang (sastradududewo.blogspot.2011).

Dalam memenuhi kebutuhan-kebutuhan keindahan, manusia mencipta berbagai macam bentuk kesenian yang hidup berdampingan saling mempengaruhi dan sebagai sumber penciptaan yang satu dengan yang lainnya. Kesenian tersebut adalah 
kesenian tradisional dan kesenian non tradisional atau kesenian modern (Soedarsono, 1999:28)

Kesenian Barongan menjadi salah satu kesenian yang digemari dan cukup populer di kalangan masyarakat Kudus terutama masyarakat Dukuh Karang Rejo, Loram Kulon. Terbukti pada setiap pertunjukan yang disajikan, antusias warga dari berbagai kalangan dan umur berbondong-bondong datang untuk menyaksikan pertunjukan kesenian Barongan. Di dalam seni barong tercermin sifat-sifat kerakyatan masyarakat Kudus, seperti sifat : spontanitas, kekeluargaan, kesederhanaan, kasar, keras, kompak, dan keberanian yang dilandasi kebenaran.

Barongan merupakan simbol atau gambaran si raja hutan yang besar, singo barong dan macan gembong Barongan berasal dari kata barong atau barung yang berarti besar. Ada pula yang menyebutkan Barongan berasal dari kata baro-baro yang artinya berbarengan atau arak-arakan di jalan. Sejarah Barongan Kudus diperkirakan sudah ada ratusan tahun lalu. Konon kesenian Barongan ini dibawa oleh Ki Gedhe Loram dan Ki Gedhe Getas untuk dakwah Islam dan kini mempunyai berbagai fungsi seperti untuk upacara kelahiran anak, ruwatan, penangkal wabah, khitanan dan untuk perayaan hari besar di Kota Kudus. Barongan Kudus diiringi dengan berbagai alat musik seperti kempul, saron, gong, slompret, dan bonang. Dalam pertunjukannya juga ditampilkan tarian jaran kepang, penthul tembem, kemudian dilengkapi dengan pecut (shomayya-man2kudus.blogspot.2009).

Pertunjukan Singo Barong bermula dari pertunjukan yang mengandung makna religi atau ritual yang dipercaya dapat terhindar dari dari gangguan makhluk halus. 
Di kalangan masyarakat Jawa, Singo Barong dianggap sebagai tari yang mengutamakan hal-hal ritual magis. Akan tetapi beberapa tahun terakhir, akibat dari perkembangan zaman maka Barongan semakin berkembang dan fungsi Barongan tidak lagi hanya sebagai kegiatan sakral melainkan untuk perayaan dan tanggapan perhelatan. Pertunjukan ini menjadi sebuah tontonan rakyat yang dikemas mengasyikkan, dengan demikian fungsi dari pertunjukan ritual telah berubah menjadi presentasi estetis (Soedarsono, 1998:11).

Barongan dari kelompok Wahyu Budaya di Dukuh Karang Rejo, Loram Kulon Kecamatan Jati Kabupaten Kudus mempunyai ciri khas tersendiri yang membedakan dengan Barongan dari luar daerah Kudus. Seperti contoh perbedaan bentuk kepala Barongan Kudus sangat berbeda dengan bentuk kepala Barongan Blora. Bentuk kepala Barongan kudus berwujud kepala macan, dihiasi dengan bulu merah dibagian atasnya , sedangkan bentuk kepala Barongan Blora berupa kepala singa dengan wajah berwarna hitam dan tidak menggunakan bulu merak.

Sesajen atau sesaji juga diberikan sebelum pertunjukan kesenian Barongan disajikan dengan tujuan untuk keselamatan. Dalam pertunjukan Barongan baik itu untuk acara hiburan, perayaan hari besar maupun untuk ruwatan dibutuhkan sesaji agar dalam proses pelaksanaannya diberikan kelancaran. Unsur utama pada kesenian Barongan contohnya adalah sesaji masih sangat berpengaruh dalam masyarakat Dukuh Karang Rejo, Loram Kulon dan mempunyai fungsi yang penting dalam setiap pementasan kesenian Barongan. 
Seiring perkembangan zaman, Barongan di Kudus mengalami beberapa perubahan namun tetap mempertahankan keasliannya. Perubahan sering terlihat pada penggunaan properti. Seperti pada kelompok kesenian Barongan Wahyu Budaya, pada setiap pertunjukan tidak lagi menggunakan topeng Penthul. Lakon Penthul lebih memilih menggunakan riasan pada wajah sang pelaku. Kelompok Barongan Wahyu Budaya dalam penyajiannya masih menerapkan alur cerita asli tanpa menambahkan tokoh-tokoh yang tidak ada sangkut pautnya dengan cerita Barongan. Dari keunikan yang dimiliki oleh kelompok Wahyu Budaya, maka tidak jarang masyarakat menantikan pertunjukan Barongan. Tidak hanya dalam perayaan hari besar saja namun pada acara syukuran kecil yang bersifat kelompok juga sering menampilkan pertunjukan Barongan Wahyu Budaya ini.

Berdasarkan pertunjukan yang disajikan oleh Barongan Wahyu Budaya lengkap dengan ritual turun temurun yang dilakukan oleh masyrakat, maka hal tersebut sangat menarik bagi peneliti untuk mengkaji Bentuk Pertunjukan Kesenian Barongan Wahyu Budaya, sehingga pengetahuan dan wawasan tentang kesenian Barongan semakin bertambah.

\subsection{Rumusan Masalah}

Berdasarkan paparan pada latar belakang permasalahan yang akan dikaji dalam penelitian ini adalah "Bagaimana bentuk pertunjukan kesenian Barongan Wahyu Budaya di Dukuh Karang Rejo Desa Loram Kecamatan Jati Kabupaten Kudus?” 


\subsection{Tujuan Penelitian}

Sesuai dengan rumusan masalah yang sudah dipaparkan maka yang menjadi tujuan penelitian adalah menganalisis dan mendeskripsikan bentuk pertunjukan kesenian Barongan Wahyu Budaya di Kudus.

\subsection{Manfaat Penelitian}

Manfaat yang diharapkan dapat diambil dari penelitian ini adalah sebagai berikut:

\section{a. Manfaat Teoritis}

1. Memberikan wawasan dan wacana mengenai Bentuk Pertunjukan Kesenian Barongan Wahyu Budaya di Dukuh Karang Rejo, Loram Kulon, Kecamatan Jati Kabupaten Kudus.

2. Mengembangkan ilmu pengetahuan ini dengan menjadi referensi.

3. Bagi Universitas Negeri Semarang akan menambah perbendaharaan tulisan atau karya ilmiah tentang kesenian Barongan khususnya mengenai bentuk pada sebuah pertunjukan, juga sebagai bahan masukan bagi peneliti berikutnya.

\section{b. Manfaat Praktis}

1. Bagi peneliti sebagai informasi dan menambah wawasan mengenai Bentuk Pertunjukan Kesenian Barongan Wahyu Budaya di Dukuh Karang Rejo, Loram Kulon, Kecamatan Jati, Kabupaten Kudus.

2. Bagi Pemerintah Daerah setempat sebagai bahan masukan untuk membina dan mengembangkan kesenian Barongan di Kabupaten Kudus. 
3. Bagi masyarakat Kabupaten Kudus khususnya masyarakat Desa Pasuruhan untuk dapat memacu agar lebih dapat melestarikan dan mengembangkan kesenian Barongan.

\section{b. Sistematika Penulisan}

Untuk mengetahui garis besar isi penelitian ini maka terlebih dahulu penulis akan menguraikan secara singkat. Garis besar yang penulis maksud adalah sebagai berikut:

Bagian Awal terdiri dari lembar judul, persetujuan pembimbing, lembar pengesahan, lembar pernyataan, motto dan persembahan, lembar abstrak, kata pengantar, daftar isi, daftar tabel, serta daftar lampiran.

Bagian isi terdiri dari lima bab yaitu pendahuluan, tinjauan pustaka dan landasan teori, metode penelitian, hasil penelitian dan penutup.

Bab I Pendahuluan yang berisi tentang alasan pemilihan judul (Latar Belakang Masalah), rumusan masalah, tujuan penelitian, manfaat penelitian, sistematika skripsi.

Bab II Tinjauan Pustaka dan Landasan Teori yang berisi tentang pengertian seni, kesenian tradisional, kesenian tradisional kerakyatan, Barongan dan kerangka berpikir.

Bab III Metode Penelitian yang berisi tentang pendekatan penelitian, data dan sumber, lokasi dan sasaran penelitian, teknik pengumpulan data (observasi, 
wawancara, dan dokumentasi), teknik keabsahan data, teknik analisa data dan instrument penelitian.

Bab IV Hasil Penelitian dan Pembahasan, yang mencakup tentang gambaran umum lokasi penelitian, sejarah berdirinya Grup Kesenian Barongan Wahyu Budaya, dan Bentuk Pertunjukan Kesenian Barongan Wahyu Budaya di Dukuh Karang Rejo, Loram Kulon, Kecamatan Jati Kabupaten Kudus.

Bab V Penutup, merupakan bab terakhir skripsi yang berisi tentang simpulan (berdasarkan hasil penelitian) dan saran (berdasarkan kesimpulan yang ada). Bagian Akhir terdapat daftar pustaka yang berkaitan dengan penelitian dan lampiran yang memuat kelengkapan-kelengkapan penelitian. 


\section{BAB II}

\section{TINJAUAN PUSTAKA DAN LANDASAN TEORI}

\subsection{Tinjauan Pustaka}

Tinjauan pustaka merupakan penelusuran pustaka yang hasil penelitian, buku, dan jurnal karya orang lain dijadikan penulis sebagai rujukan ataupun perbandingan terhadap penelitian penulis. Peneliti merujuk pada beberapa sumber sebagai rujukan dan perbandingan antara lain

Skripsi Sri Utami (2001) mengambil judul "Bentuk Penyajian dan Usaha Pengembangan Seni Barong Sekar Joyo Kelurahan Kunden Blora", memiliki persamaan yakni keduanya sama-sama meneliti tentang kesenian rakyat Barong atau disebut juga Barongan yang keduanya sama-sama membahas mengenai bentuk dari sebuah pertunjukan. Perbedaan terletak pada objek kelompok kesenian yang diteliti. Pada penelitian Sri Utami mengambil objek kesenian Barong Sekar Joyo Kunden Blora, sedangkan dalam penelitian ini objek kesenian yang diambil adalah Barongan Wahyu Budaya Loram Kulon Kudus. Dari objek yang diteliti berbeda maka akan didapat informasi yang berbeda pula mengenai bentuk penyajiannya.

Berdasarkan skripsi dari Cicilia Ika Rahayu Nita (2006) dengan judul “Bentuk dan Fungsi Pertunjukan Jathilan Dalam Upacara Ritual Kirab Pusaka Pada Masyarakat Kampung Tidar Magelang”. Kedua penelitian sama-sama membahas tentang bentuk dan fungsi pertunjukan. Perbedaan terletak pada jenis kesenian yang 
dibahas. Dalam penelitian Cicilia mengambil jenis kesenian Jathilan, sedangkan penulis mengambil jenis kesenian Barongan.

Berdasarkan artikel yang ditulis oleh Dwi Jadmiko (2014) dengan judul Seni Tari Dalam Barongan (http://Jadmiko.blogspot.com/2014/makalahBarongan) memiliki kesamaan yakni sama-sama mengambil penelitian mengenai bentuk pertunjukan kesenian Barongan, namun berbeda objek kesenian dan fungsi. Dwi Jadmiko mengambil objek kesenian Barongan Markocik Budoyo Kudus dan mengerucut mengenai fungsi Barongan dalam acara ruwatan sedangkan peneliti mengambil objek kesenian Barongan Wahyu Budaya Kudus dengan mendeskripsikan bentuk pertunjukan kesenian Barongan.

Berdasarkan rujukan dari beberapa sumber skripsi dan artikel, dengan dasar judul bentuk pertunjukan kesenian barongan Wahyu Budaya, dan dengan kajian pada kelompok yang berbeda. Penerapan ini diharapkan akan menunjukkan hasil yang lebih baik dan memberi manfaat bagi peneliti selanjutnya.

\subsection{Landasan Teoretis}

\subsubsection{Kesenian}

Aristoteles juga mengartikan seni sebagai bentuk yang pengungkapannya dan penampilannya tidak pernah menyimpang dari kenyataan dan seni itu adalah meniru alam. Immanuel Kant mengatakan seni adalah sebuah impian karena rumus-rumus tidak dapat mengihtiarkan kanyataan. Sedangkan menurut Ki Hajar Dewantara, seni merupakan hasil keindahan sehingga dapat menggerakkan perasaan indah orang yang 
melihatnya, oleh karena itu perbuatan manusia yang dapat mempengaruhi dapat menimbulkan perasaan indah itu seni (Sumardjo, 2000:58-66).

Seni berasal dari bahasa Melayu yang berarti kecil. Seni adalah keindahan dan seni adalah tujuan yang positif menjadikan penikmat merasa dalam kebahagiaan. Seni adalah bentuk yang pengungkapannya dan penampilannya tidak pernah menyimpang dari kenyataan dan seni itu adalah meniru alam. Seni adalah sebuah impian karena rumus-rumus tidak dapat mengihtiarkan kenyataan (Wikipedia Bahasa Indonesia). Karya seni merupakan sebuah benda atau artefak yang dapat dilihat, didengar, atau dilihat dan sekaligus didengar (visual, audio, dan audio-visual), seperti lukisan, music dan teater (Sumardjo, 2000:45).

Seni memiliki karya yang diciptakan dengan keahlian luar biasa. Seni adalah rasa keindahan dan diciptakan untuk melanjutkan perasaan-perasaan tersebut. Seni merupakan penjelmaan rasa indah yang terkandung dalam jiwa orang, dilahirkan dengan perantara alat-alat komunikasi dalam bentuk yang dapat ditangkap oleh indra pendengar (suara), indra penglihat (rupa), atau dilahirkan dengan gerak (Ensiklopedia Indonesia, 1992:3080). Menurut Sunarto dalam Muhtar (2010:34) dalam hal kodratesensial dan fungsi dari seni terdapat tiga teori yaitu bentuk hakiki merupakan salah satu sifat yang penting bagi seni, seni sebagai ekspresi dari perasaan manusia dan seni lebih berfungsi sebagai simbol daripada ekspresi.

Seni tari merupakan seni yang dinikmati melalui media penglihatan dan pendengaran (audio-visual). Tari merupakan sebuah seni kolektif, sebab dalam proses dan kerangka wujudnya tempat dibentuk oleh berbagai disiplin seni yang lain, 
misalnya sastra, musik, seni rupa, dan seni drama (Hidajat, 2005:1). Pengertian tari menurut Soedarsono dalam bukunya : Djawa dan Bali: Dua Pusat Perkembangan Drama Tari Tradisional di Indonesia. Sebagai berikut : Tari adalah ekspresi jiwa manusia yang diungkapkan melalui gerak-gerak ritmis yang indah.

Tari mempunyai arti penting dalam kehidupan manusia karena dapat memberikan berbagai manfaat, seperti sebagai hiburan dan sarana komunikasi. Perubahan pola pikir masyarakat berpengaruh terhadap fungsi dan struktur tari, dan tari akan senantiasa menyesuaikan dengan konteks zamannya. Tari sebagai karya seni merukan alat ekspresi dan sarana komunikasi seorang seniman kepada orang lain (penonton atau penikmat). Sebagai alat ekspresi, tari mampu menciptakan untaian gerak yang dapat membuat penikmatnya peka terhadap sesuatu yang ada dan terjadi. Tari adalah sebuah ungkapan, pernyataan, dan ekspresi penciptanya yang memuat komentar-komentar mengenai realitas, yang bisa merasuk di benak penikmatnya setelah pertunjukan selesai (Jazuli, 2007:4).

Kesimpulan dari beberapa pendapat di atas yaitu kesenian tidak dapat berkembang sendiri tanpa dukungan masyarakat. Alat yang digunakan untuk berkomunikasi adalah tubuh seorang penari. Tubuh itulah yang akan bergerak menjelajahi ruang dan waktu ketika kita sedang menari. Misalnya saat kita bergerak memutar, meloncat, menjatuhkan diri ke lantai, menjalin gerakan-gerakan dengan orang lain. Seringkali setiap orang menari mempunyai maksud dan tujuan tertentu. Hal inilah yang menyebabkan munculnya bentuk-bentuk tari yang tidak setiap orang bisa melakukannya. 


\subsubsection{Kesenian Tradisional}

Seni tradisional adalah unsur kesenian yang menjadi bagian hidup masyarakat dalam suatu kaum,puak,suku,bangsa tertentu. Tradisional adalah aksi dan tingkah laku yang keluar alamiah karena kebutuhan dari nenek moyang yang terdahulu. Menurut Kayam, kesenian tradisional terjalin rapat dengan ritus keagamaan dan kemasyarakatan, ia mencerminkan secara setia dan hampir secara harfiah denyut nadi masyarakat itu ( Khayam, 1981:25).

Tradisional merupakan istilah yang berasal dari kata tradisi yang berasal dari bahasa latin yang berarti mewariskan. Warisan ini kemudian diturunkan dari generasi ke generasi berikutnya melalui proses. Jadi dengan kata lain tradisi artinya warisan budaya dari masa lalu ke masa sekarang. Hal itu dapat berupa pandangan hidup, kepercayaan, kesenian, upacara adat dan sebagainya. Kesenian tradisional merupakan ungkapan batin yang dinyatakan dalam bentuk simbolis menggambarkan arti kehidupan penduduknya, oleh karena itu nilai yang terkandung dalam kesenian tradisional adalah nilai-nilai yang bersumber dari pandangan hidup masyarakat pendukungya (Bastomi, 1998:16).

Menurut Sinaga (dalam Harmonia, 2007:71) kesenian tradisional merupakan bentuk seni yang bersumber dan berakar serta telah disarankan sebagai milik sendiri oleh masyarakat di lingkungannya. Kehidupan dan pengolahan seni tradisional didasarkan atas cita rasa masyarakat pendukungnya, meliputi pandangan hidup, nilai kehidupan tradisi, rasa etis, estetis serta ungkapan budaya lingkungan yang kemudian diwariskan pada generasi berikutnya. Kesenian sebagai salah satu cabang budaya 
yang berkaitan dengan cita rasa merupakan hasil budi daya manusia, menurut kodratnya manusia yang hidup akan selalu mengenal keindahan.

\subsubsection{Kesenian Tradisional Kerakyatan}

Kesenian tradisional kerakyatan adalah bentuk kesenian tradisional yang hidup dan berkembang di kalangan rakyat jelata dan biasa disebut juga kesenian rakyat. Tari-tarian tradisional kerakyatan sangat sederhana dan kurang mengindahkan norma-norma kehidupan dan bentuk-bentuk yang berstandar. Gerakan-gerakan tariannya sangat sederhana karena yang dipentingkan adalah keyakinan yang terletak dibelakang tarian tersebut.

Kesenian rakyat dikonsumsi oleh masyarakat, terutama yang memiliki ikatan dengan kesenian rakyat tersebut. Masyarakat semestinya membutuhkan pelarian sejenak dari monotoni kehidupan mereka sehari-hari. Seni rakyat tumbuh dari kalangan rakyat secara langsung lantaran dari masyarakat kecil saling mengenal secara akrab dan bentuknya yang sederhana sehingga mudah untuk dipahami.

Tari tradisional kerakyatan adalah tari yang tumbuh secara turun temurun dalam lingkungan masyarakat etnis, atau berkembang dalam rakyat, untuk itu sering disebut Folkdance (Hidajat, 2005:15). Sisa-sisa peninggalan cara bergerak yang khas dari suatu bangsa biasanya dikenal sebagai tarian rakyat. Tarian rakyat tetap berlanjut dalam pertunjukan-pertunjukan festival, tarian rakyat secara kasarnya dapat pula berarti “tarian otentik" dari rakyat-rakyat tertentu (Murgiyanto, 1977:2).

Kesenian rakyat dibeberapa lingkungan Indonesia tercipta secara anonym, menjangkau satu wilayah yang terbatas, tidak banyak mengalami perkembangan dan 
benar-benar merupakan refleksi dari satu kebudayaan petani. Dia adalah bentuk seni fungsional atau seni utilitas terhadap masyarakatnya. Baik tema, pengungkapannya lewat gerak maupun saat menampilkannya, tidak terpisah dari kepentingan menyeluruh dari sang kosmos (aturan) tersebut. Maka Kayam (1981:90) menyebutkan tari-tarian itu menyangkut segala hal ikhwal yang berkaitan dengan kehidupan masyarakat petani. Dia akan menyangkut sang petani, sang padi dan sang badan halus yang menjaga padi dan petani.

Menurut sifat seni tari, seni tari yang banyak terdapat di setiap daerah di Indonesia pada pokoknya dapat digolongkan menjadi tiga sifat: primitif, klasik, modern. Perbedaan antara tari primitif dan tari klasik bentuk dan sejarah tari. Ciriciri tari primitif atau lebih dikenal dengan istilah tarian rakyat banyak lahir dan tumbuh di daerah-daerah Indonesia adalah bentuk yang sangat sederhana baik dari gerak, pakaian, riasan, maupun tema, yang biasanya dilakukan dengan spontanitas, tidak ada peraturan-peraturan atau hukum-hukum yang seragam dan tertentu. Warna pakaian yang digunakan umumnya adalah putih, hitam, merah. Tari kerakyatan dapat dilihat di daerah Indonesia, terutama di daerah pedalaman yang terpisah dari kota. Tari klasik adalah sebuah tari yang lahir dan tumbuh di daerah-daerah atau disebut juga negara yang dapat hidup dan berkembang disegala zaman kendati telah mengalami banyak perubahan. Perubahan biasanya hanya menyangkut segi teknis, sedang ciri dan watak dari tari tidak berubah. Selain itu tari klasik mempunyai hukum-hukum yang sangat kuat, dalam perwujudannya tari klasik lebih cenderung 
pada keabstrakan, kadang-kadang simbolik dengan latar belakang falsafah yang dalam (Kussudiarja, 2000:14).

\subsubsection{Bentuk Pertunjukan}

Bentuk pertunjukan tari merupakan keseluruhan suatu penyajian tari yang berfungsi untuk mengungkapkan ekspresi jiwa manusia yang dikomunikasikan melalui gerak antara seniman dengan penikmat atau penghayat seni. Suatu sajian tari akan memiliki nilai estetis apabila di dalamnya terdapat elemen-elemen pertunjukan secara terpadu. Elemen-elemen dalam pertunjukan adalah sebagai berikut:

\subsubsection{Gerak Tari}

Gerak sebagai media ungkapan seni pertunjukan merupakan salah satu diantara pilar penyangga wujud kesenian pertunjukan yang dapat dilihat sedemikian terangkat. Gerak berdampingan dengan suara atau bunyi-bunyian merupakan caracara yang dipergunakan untuk mengutarakan berbagai perasaan dan pikiran yang paling awal dikenali oleh manusia (Hermin Kusmayanti, 2000:76).

Menurut Jazuli (1994:4) dalam gerak terkandung tenaga atau energi yang mencakup ruang dan waktu. Artinya gejala yang menimbulkan gerak adalah tenaga dan bergerak berarti membutuhkan ruang dan waktu. Tenaga, ruang dan waktu diuraikan sebagai berikut:

\section{Tenaga}

Tenaga merupakan bagian dalam gerak, sedangkan gerak merupakan tata hubungan antara aksi, usaha, dan ruang di mana tidak satupun dari aspek tersebut dapat hadir tanpa yang lain dalam motif, tetapi satu atau lebih dapat mendapatkan 
penekanan dari yang lain. Tenaga dari tubuh manusia diperlukan untuk mewujudkan suatu gerak selain mengandalkan kekuatan otot juga mengandalkan kekuatan emosional atau rasa yang penuh pertimbangan maka dalam menghasilkan gerak seorang koreografer perlu mengontrol arus dinamis tari melalui organisasi sensitif dari ketegangan gerak (Hawkins dalam Soedarsono, 1978:4).

\section{Ruang}

Ruang adalah sesuatu yang tidak bergerak dan diam sampai gerak yang terjadi didalamnya mengintrodusir waktu, dengan cara demikian mewujudkan ruang sebagai suatu bentuk atau ekspresi khusus yang berhubungan dengan waktu yang dinamis dari gerakan (Hadi, 1996:13). Dalam tari, penataan ruang ditambah dengan penataan para pelaku, penataan gerak, warna, suara, dan waktu, dan semuanya dicakup dengan kata koreografi (Djelantik, 1999:24).

Hal-hal yang berkaitan dengan ruang antara lain adalah: a). Garis sebagai bentuk yang artinya lebih daripada titik, karena bentuknya sendiri, garis menimbulkan kesan tersendiri pada pengamat. Garis yang kencang memberikan perasaan yang lain daripada garis yang membelok atau melengkung (Djelantik, 1999:22), b). Volume merupakan isi keruangan yang berhubungan dengan besar kecilnya jangkauan gerak tari (Murgiyanto, 1986:27), c). Arah merupakan aspek yang mempengaruhi efek estetik ketika bergerak melewati ruang selama tarian itu berlangsung, sehingga ditemukan pola-polanya dan sering dipahami sebagai pola lantai (Sumandiyo, 2003:13), d). Level merupakan posisi-posisi untuk gerak, terdiri 
atas level gerak lengan dan level gerak tungkai (Soedarsono, 1978:16-17), e). Fokus pandangan.

\section{Waktu}

Struktur dari waktu dalam tari meliputi aspek tempo, ritme dan durasi. Tempo adalah cepat lambatnya sebuah gerak. Tempo mempunyai kesan. Kesan lambat memiliki arti tenang dan tempo cepat memiliki arti riang atau lincah. Ritme dalam gerak merupakan hubungan timbal balik atau perbedaan dari jarak waktu cepat lambat (Hadi, 1996:31).

\subsubsection{Pelaku (penari)}

Penari adalah pembawa tari. Penari yang bersungguh-sungguh akan hidup dengan seni tarinya atau akan hidup untuk seni tari banyak sekali tantangannya. Sebab penari harus dapat mempertahankan, baik mutu seni yang dibawakannya maupun prestasi menarinya. Penari harus bertanggung jawab tari yang dibawakan, karena penari yang tidak sungguh-sungguh dalam menari tidak hanya akan menjatuhkan seni tarinya saja, tetapi akan membawa nama kurang baik juga bagi dirinya sebagi penari (Kussudiardja, 2000:19).

Semua jenis seni pertunjukan memerlukan pelaku dalam penyajian, artinya seniman yang terlibat langsung atau tidak langsung dapat mengetengahkan atau menyajikan bentuk seni pertunjukan tersebut. Bentuk pertunjukan tari tertentu ada yang melibatkan pelaku laki-laki dan pelaku perempuan. Demikian pula halnya dengan usia atau umur pelaku seni pertunjukan juga bervariasi, yaitu pelaku anak- 
anak, remaja, dewasa sampai orang tua. Mengenai jumlah pelaku juga bervariasi, yaitu pelaku tunggal, berpasangan dan kelompok (Cahyono, 2002:79).

Kesiapan tubuh secara fisik bagi seorang penari sangat vital keberadaannya untuk melakukan aktifitas gerak tari. Ketrampilam tari yang dimiliki dapat dibentuk melalui kesiapan organ-organ tubuh (fisik) yang akan digunakan untuk melakukan gerak. Kondisi yang prima dapat dicapai apabila seorang penari dengan sadar melakukan kesiapan-kesiapan seluruh tubuh dengan rutin (continue). Dengan arti kata lain, bahwa secara sadar seorang penari harus melakukan pengolahan gerak tubuh secara merata dan sempurna.

Pengertian pengolahan tubuh bagi penari atau yang sering disebut dengan olah tubuh adalah suatu kegiatan manusia mengolah tubuh yang dengan sengaja menjadikan barang mentah menjadi barang jadi, sehingga siap untuk dipergunakan. Olah tubuh bagi seorang penari adalah suatu bentuk aktivitas yang dilakukan dengan jalan melakukan susunan latihan yang teratur meliputi otot-otot, persendian, dan seluruh organ tubuh agar selalu siap berfungsi bergerak dengan baik dan optimal serta diharapkan mampu menambah kualitas gerak.

\subsubsection{Iringan}

Iringan atau musik merupakan unsur pendukung dan pelengkap pada penyajian tari. Iringan akan menambah suasana kedinamisan dalam tari dan dapat memberi nilai estetis tersendiri. Iringan adalah pasangan tari yang senantiasa tidak dapat dipisahkan satu dengan yang lain karena keduanya saling menguntungkan. 
Pada zaman prasejarah andaikata musik (iringan) dipisahkan dari tari maka musik itu tidak mempunyai nilai estetis apapun (Curt Sachs dalam Jazuli 1994:9). Hal ini bisa kita lihat pada musik primitif yang tidak pernah lepas dari gerak-gerak tertentu (tari), seperti musik yang ada di daerah pedalaman Kalimantan, Sulawesi dan Irian Jaya. Iringan musik tidak hanya sekedar iringan tetapi merupakan patner pada sebuah tari, sebab tari tanpa iringan akan terasa sekalipun menggunakan bentuk iringan yang sangat sederhana.

Iringan musik pada dasarnya dibagi menjadi dua, yaitu iringan internal dan iringan eksternal. Iringan internal yaitu iringan yang berasal dari penari itu sendiri, misalnya suara tepuk tangan. Sedangkan iringan eksternal adalah iringan alat musik (Murgiyanto, 1983:43). Alat musik yang digunakan dalam kesenian Barongan yaitu kendang, slompret, saron, kempul, kenong, kethuk, demung dan gong. Iringan eksternal digunakan dalam pertunjukan Barongan sebagai pengendali dan pemberi suasana dalam setiap adegan.

Menurut Jazuli (1994:10) fungsi musik dalam tari dapat dikelompokkan menjadi tiga yaitu sebagai pengiring tari, sebagai pemberi suasana, dan sebagai ilustrasi tari. Pengiring tari berarti peranan musik hanya untuk mengiringi atau menunjang penampilan tari sehingga tidak banyak menentukan isi tarinya. Iringan (musik) sebagai pemberi suasana, berarti mampu memberi kesan dan suasana tertentu pada suatu tarian, sedangkan iringan sebagai ilustrasi tari adalah tari yang menggunakan iringan baik sebagai pengiring atau pemberi suasana pada saat tertentu saja tergantung kebutuhan garapan tari. 


\subsubsection{Tata Rias dan Busana}

Tata rias dan busana merupakan pelengkap pertunjukan tari untuk memberikan tekanan atau aksentuasi bentuk dan memperkuat garis-garis ekspresi pada wajah penari sesuai dengan tuntutan karakter tarian (Murgiyanto, 1983:103). Kostum atau busana dalam tari dimaksudkan untuk membantu ekspresi gerak karena dengan kostum dapat membantu mengubah penampilan seorang penari sesuai dengan karakter tarinya. Oleh karena itu tata rias dan busana merupakan pelengkap sebuah pertunjukan.

\subsubsection{Properti Tari}

Properti tari adalah segala perlengkapan atau peralatan yang terkait langsung dengan penari, seperti sebagai bentuk senjata, aksesoris yang digunakan dalam menari (Jazuli, 2001:103). Tujuan penggunaan properti tari untuk menambah nilai estetika tarian yang ditampilkan serta sebagai media dalam penyampaian pesan dan makna dari tarian tersebut. Tidak hanya properti tari yang dibutuhkan, properti panggung atau stage property juga diperlukan untuk mendukung suatupertunjukan tari, contohnya seperti hiasan pepohonan, gambar-gambar yang berada di belakang (back drop). Properti yang digunakan dalam kesenian Barongan adalah topeng barong, topeng tembem, topeng celeng, dan kuda lumping yang terbuat dari anyaman bambu menyerupai bentuk kuda.

\subsubsection{Pola Lantai}

Pola lantai merupakan garis-garis yang dilalui penari atau garis-garis yang dibuat formasi oleh penari. menurut Soedarsono (1978:42) pola lantai dasar dibagi 
dua yaitu pola lantai garis lurus dan pola lantai garis melengkung. Pola lantai garis lurus memberikan kesan sederhana taetapi kuat, seperti garis horizontal dan vertikal. Pola lantai garris lengkung mengesankan lembut dan juga lemah, seperti lingkaran, setengah lingkaran dan juga lengkung.

\subsubsection{Tempat dan Waktu Pertunjukan}

Suatu pertunjukan atau pementasan tari bagaimanapun bentuknya memerlukan suatu tempat untuk digunakan pentas dan penonton. Kita mengenal berbagai macam bentuk tempat pertunjukan seperti lapangan terbuka atau di arena terbuka, di pendopo, dan panggung. Pada tempat terbuka kita bisa menyaksikan pertunjukan tari

tradisional kerakyatan. Pertunjukan Barongan sering dipergelarkan di lapangan terbuka. Pada pertunjukan Barongan Wahyu Budaya juga dilakukan di lapangan terbuka.

Durasi waktu pertunjukan biasanya hanya setengah hari yaitu dimulai pada pukul 9 pagi sampai pukul 11.30 WIB. Namun ada juga yang dilanjutkan pada pukul 12.30 sampai selesai.

\subsubsection{Masyarakat Sebagai Penonton}

Menurut Kamus Besar Bahasa Indonesia, masyarakat adalah sejumlah manusia yang terikat oleh suatu kebudayaan. Definisi masyarakat adalah suatu keseluruhan kompleks hubungan manusia yang luas sifatnya. Arti dari keseluruhan kompleks yaitu keseluruhan terdiri atas bagian-bagian yang membentuk suatu kesatuan (Peter, 1991:46). Masyarakat ialah keseluruhan hubungan-hubungan ekonomis, baik 
produksi maupun konsumsi, yang berasal dari kekuatan-kekuatan produksi ekonomis, yakni teknik dan karya.

Pengertian masyarakat berasal dari bahasa Arab syaraka yang berarti ikut serta, berpartisipasi. Masyarakat memiliki arti sekelompok orang yang membentuk sebuah system semi tertutup atau terbuka. Masyarakat terdiri atas individu-individu yang saling tergantung satu sama lain atau disebut zoon polition (Koentjaraningrat, 2000:143).

Pengertian lain dari Koentjaraningrat mengatakan masyarakat adalah kesatuan hidup manusia yang berinteraksi menurut suatu sistem adat istiadat tertentu yang bersifat kontinu dan terikat oleh suatu rasa identitas bersama. Masyarakat dibedakan dalam arti masyarakat luas dan masyarakat sempit, masyarakat luas contohnya masyarakat se-Indonesia sedangkan masyarakat sempit yaitu masyarakat yang terdiri dari suatu warga atau kelompok yang hidup di desa atau kota yang terikat dalam kesatuan-kesatuan khusus.

Kehidupan masyarakat tidak dapat terlepas dari kesenian karena manusia selalu menginginkan keindahan dengan cara menciptakan sesuatu yang dapat dikatakan indah. Karena keindahan selalu menimbulkan kebahagiaan dan sebagai kodratnya, manusia ingin bahagia. Terwujud pada hasil lukisan, topeng dan patung, tari-tarian sederhana, dongeng yang tidak tertulis dalam lingkungan suku bangsa yang hidupnya masih sederhana dan sebagainya. Dengan demikian terhiaslah hidup manusia melalui seni lukis, seni pahat, seni suara, seni tari, seni sasta dan lain-lainya. 
Tari kerakyatan merupakan produk kolektif dari suatu kelompok masyarakat. Ada unsur kebersamaan pemahaman dan kepentingan terhadap tarian yang dibawakan. Masyarakat dan tarian seperti ada ikatan batin yang spontan, jujur, tulus serta ikhlas. Demikian pula dalam tarian kerakyatan yang bersifat hiburan, sudah pasti manusia membutuhkan hiburan. Tarian sebagai suatu hiburan menekankan fungsi utamanya pada terjalinnya komunikasi dengan mudah antara penonton (pencari hiburan) dengan materi tari yang dibawakan oleh penari.

Tari kerakyatan yang bersifat hiburan biasanya dekat dengan tari-tari pergaulan. Jalinan komunikasi antara penonton dan penari dipererat. Tari pergaulan menciptakan suasana hubungan yang akrab. Karenanya, tarian pergaulan harus punya citra spontanitas tinggi, gerakannya seakan-akan mudah untuk ditirukan, menyambung hubungan yang akrab, memancing keterlibatan penonton tanpa melepas dimensi estetik dan etiknya (Kussudiardja, 2000:132).

Penonton adalah orang-orang atau sekelompok manusia yang sengaja datang untuk menyaksikan tontonan. Penonton juga dapat dikatakan sebagai apresiator, penikmat, penilai dan sebagainya. Maka kedatangan penonton dalam suatu pertunjukan sangat bersifat mutlak. Tanpa adanya penonton, suatu pertunjukan akan terasa sia-sia atau mubadzir karena sebuah pertunjukan membutuhkan suatu penilaian, penghargaan atau kritikan dari penonton (senibudaya.blogspot.co.id).

Menonton, mengapresiasi adalah sikap menerima, menghargai sekaligus mengkritisi pesan yang disampaikan dari sebuah pertunjukan karya seni. Penilaian pada pertunjukan karya seni untuk setiap penonton sangatlah berbeda dan bersifat 
relatif. Oleh sebab itu, berpijak pada keragaman latar belakang penonton dan pengalaman seni, penonton dalam hubungan seni dapat dibedakan menjadi tiga golongan, yakni penonton: awam, tanggap dan kritis.

1. Penonton awam adalah penonton penikmat seni dengan kecenderungan kurang atau tidak dibekali dengan pengetahuan dan pengalaman seni.

2. Penonton tanggap adalah penonton bersikap respondensif dengan kecenderungan mempunyai wawasan dan pengalaman seni, tetapi tidak ditindaklanjuti untuk mengulas pada apa yang telah disaksikan, cukup untuk dinikmati dan dipahami sendiri.

3. Penonton kritis adalah penonton dengan bekal ilmu dan pengalaman seni lalu melakukan ulasan atau menulis kritik dari sebuah pertunjukan dan dipublikasikan dalam forum ilmiah, diskusi sampai media cetak dan elektronik.

\subsubsection{Barongan}

Kesenian Barongan merupakan suatu cabang kesenian tradisional yang bernafaskan kerakyatan. Barongan berawal dari kata "Barong" mendapat akhiran “an" yang berarti suatu bentuk atau rupa yang menirukan Barong. Kesenian Barongan hingga saat ini masih sulit ditentukan sejak kapan mulai masuk di Kudus. Namun dari beberapa keterangan mengatakan seni Barongan di Kudus dahulunya merupakan peninggalan Sunan Kalijaga dan Sunan Kudus yang mensyi'arkan agama Islam melalui berbagai macam kesenian dan salah satunya adalah seni Barongan. 
Barongan berasal dari kata barong yang diambil dari nama seorang penguasa Kerajaan Lodaya yang memiliki tubuh manusia besar dan berkepala singa yang bernama Singa Barong.

Tari Barong pada Ensiklopedia Tari Jawa Tengah dijelaskan bahwa salah satu tari bebali yang sangat angker di Bali dan diduga merupakan peninggalan kebudayaan Pra-Hindu. Astini (dalam Harmonia, 2003:91), kata barong berasal dari kata bahrwang yang berarti binatang beruang. Beruang tidak dijumpai di Bali, tetapi merupakan binatang yang mempunyai kekuatan gaib dan dianggap sebagai pelindung. Jika dilihat dari bentuk kedoknya, barong yang ada di Bali tampak adanya suatu perpaduan antara kebudayaan Hindu yang bercorak Budha karena bentuk kedok seperti itu juga terdapat pada negara-negara penganut agama Budha seperti China dan Jepang.

Kesenian Barongan yang berkembang di berbagai daerah sampai saat ini tidak dapat lepas dari sejarah Barong Bali, yang menurut perkembangannya kemudian Barong yang ada di Bali diwujudkan tidak hanya dalam bentuk hewan berkaki empat, tetapi berupa manusia purba, setan dan makhluk-makhluk lainnya yang berkaki dua. Suatu hal yang perlu dicatat bahwa yang disebut Barong Bali yaitu pembentukannya selalu terdiri dari unsur topeng atau punggalan yang diikatkan menjadi satu dengan gelungan atau haiasan kepala yang juga menjadi satu dengan raga (badan) barong. Barong dianggap sebagai pelindung masyarakat karena Barong mempunyai Kekuatan gaib yang dapat menolong masyarakat, dan kekuatan tersebut biasanya terletak pada punggalannya khususnya pada mata dan jenggot. Jenggot 
barong terbuat dari rambut manusia yang ditata rapi di bawah janggutnya. Panjang dari jenggot tersebut kurang lebih $25 \mathrm{~cm}$ sampai $30 \mathrm{~cm}$ (Astini, 2003:91).

Menurut Dibia (1979:4) dalam Astini, berdasarkan ciri-cirinya tari Barong merupakan tari rakyat atau kerakyatan. Adapun cirri-ciri tari rakyat adalah tariannya sederhana, spontan, dan tidak terlalu diikat oleh peraturan-peraturan tertentu dan berfungsi sebagai tari ritual magis. Seperti jenis Barong Blas-blasan diadakan disaat suatu desa diserang oleh wabah penyakit atau malapetaka lainnya yang bisa mengganggu ketentraman rakyat (Astini, 2003:94).

Di pulau Jawa, Barongan termasuk kesenian tradisional rakyat yang bersifat menghibur (hiburan) dan diwujudkan dalam bentuk tarian. Bersifat hiburan dan mengandung sindiran-sindiran terhadap kejadian di masyarakat. Pengertian Barongan pada Kamus Besar Bahasa Indonesia edisi kedua (1995:835) adalah:

1. Tarian tradisional dalam arena terbuka yang berfungsi sebagai hiburan rakyat, mengandung unsure magis, penari utama adalah orang berkepala singa dengan hiasan bulu merak, ditambah beberapa penari bertopeng dan berkuda lumping yang semuanya laki-laki.

2. Tontonan tradisional sebagai hiburan rakyat yang mengandung unsur humorhumor.

Kesimpulan yang dapat diambil dari beberapa definisi di atas, Barongan adalah sebuah kesenian budaya berbentuk teater yang dilakukan oleh sekelompok pemain atau penari dengan berbagai karakter dan perwatakan pelaku dengan menggunakan 
topeng yang besar berkepala singa yang dikenal dengan nama Singa Barong, yang berfungsi sebagai hiburan atau dapat juga sebagai sarana ritual.

\subsection{Kerangka Berpikir}

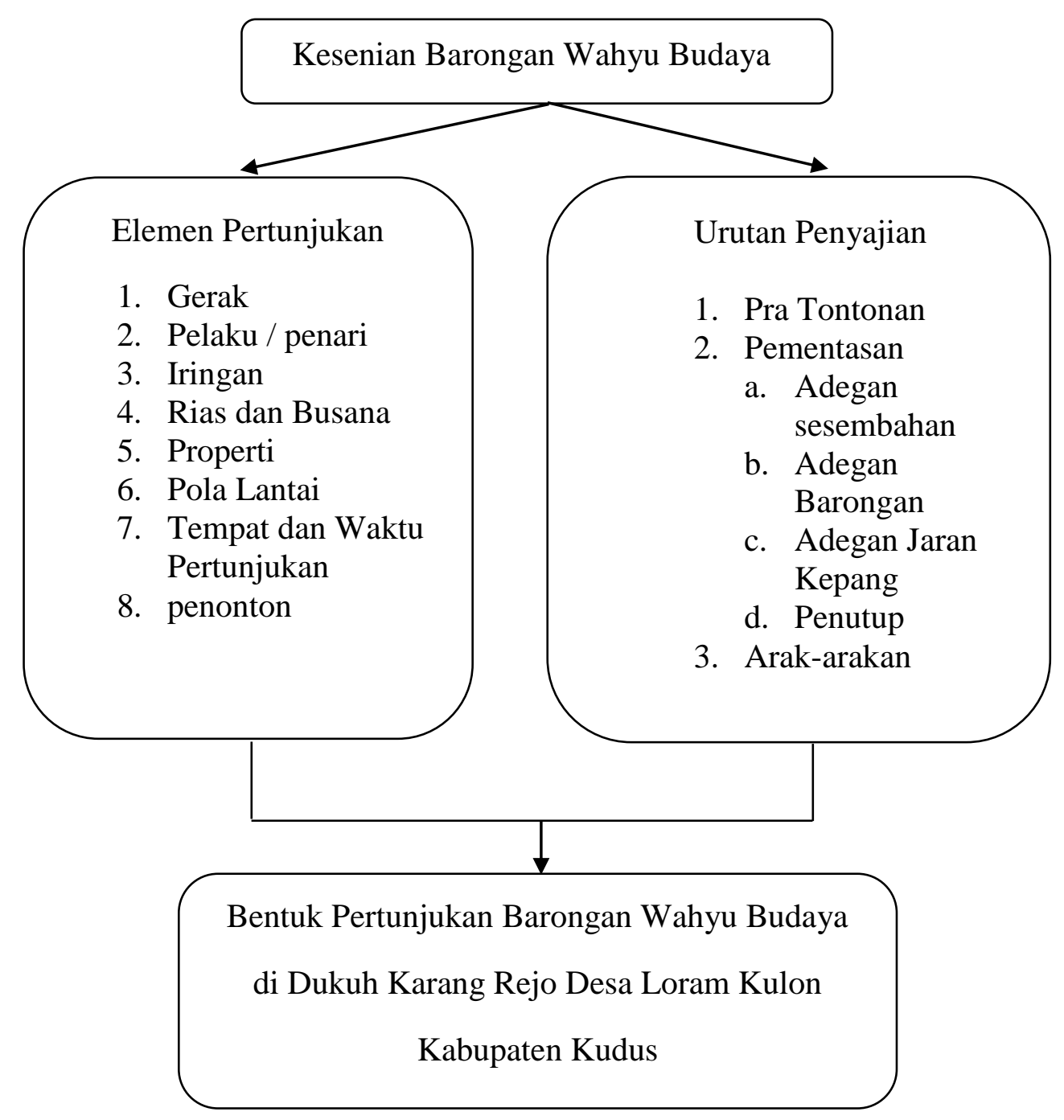

Keterangan : Kesenian Barongan Wahyu Budaya, bentuk pertunjukan memiliki elemen-elemen yang meliputi dari gerak, pelaku/penari, iringan, tata rias dan busana, properti, pola lantai, tempat dan waktu pementasan dan penonton. Kesenian 
Barongan Wahyu Budaya dalam pementasannya memiliki tiga tahapan yaitu tahap awal (pra tontonan), tahap inti (pertunjukan Barongan), tahap akhir (penutup). 


\section{BAB III}

\section{METODE PENELITIAN}

Metodologi penelitian merupakan aspek yang berperan dalam kelancaran atau keberhasilan dalam penelitian. Metodologi penelitian adalah suatu cara untuk memperoleh pengetahuan dan memecahkan suatu permasalahan yang di hadapi. Metode penelitian sering dikacaukan dengan prosedur penelitian atau teknik penelitian dikarenakan masalah metode penelitian dan prosedur penelitian saling berhubungan dan sulit dibedakan. Metode penelitian membicarakan mengenai tata cara pelaksanaan penelitian, sedangkan prosedur penelitian membicarakan alat-alat yang digunakan dalam mengukur atau mengumpulkan data penelitian.

Suatu penelitian kebenaran metodologi penelitian mutlak diperlukan. Hal ini supaya seseorang peneliti mempunyai dasar, arah dan langkah-langkah yang harus ditempuh untuk dapat memecahkan suatu permasalahan yang menjadi obyek dalam penelitian sehingga hasil dari penelitian nanti dapat dipahami dan dapat dipertanggung jawabkan kebenarannya.

Berkaitan dengan metodologi penelitian tersebut, berikut ini diuraikan hal-hal yang meliputi:

\subsection{Pendekatan Penelitian}

Metode penelitian yang digunakan dalam penelitian bentuk pertunjukan kesenian Barongan Wahyu Budaya adalah metode penelitian kualitatif. Metode penelitian kualitatif berupa kata-kata dan gambar yang berasal dari naskah, hasil wawancara, catatan lapangan, dokumen pribadi atau resmi (Jazuli, 2001:19). 
Penelitian kualitatif berakar pada latar alamiah sebagai keutuhan, mengandalkan manusia sebagai alat penelitian, memanfaatkan pada metode kualitatif, mengadakan menganalisis data secara induktif, mengarahkan sasaran penelitiannya pada usaha menemukan teori dasar, bersifat deskriptif, lebih mementingkan proses daripada hasil, membatasi studi dengan fokus, memiliki seperangkat kriteria untuk memeriksa keabsahan data, rancangan penelitiannya bersifat sementara dan hasil penelitiannya disepakati oleh kedua belah pihak yaitu peneliti dan subjek penelitiannya (Moleong, 2001:27).

Penelitian kualitatif memiliki tiga kemungkinan yang akan terjadi terhadap masalah yang dibawa peneliti dalam penelitian. Yang pertama masalah yang dibawa oleh peneliti tetap, sehingga sejak awal sampai akhir penelitian sama. Dengan demikian judul proposal dengan judul laporan penelitian sama. Yang kedua, masalah yang dibawa peneliti setelah memasuki penelitian berkembang yaitu memperluas atau memperdalam masalah yang telah disiapkan. Dengan demikian tidak terlalu banyak perubahan, sehingga judul penelitian cukup disempurnakan. Yang ketiga, masalah yang dibawa peneliti setelah memasuki lapangan berubah total, sehingga harus ganti masalah. Dengan demikian judul proposal dan judul penelitian tidak sama sehingga judulnya ganti (Sugiyono, 2008:205).

Peneliti menggunakan metode penelitian kualitatif yang bersifat deskriptif karena permasalahan yang dibahas dalam penelitian ini bertujuan menggambarkan dan menguraikan yang berkaitan dengan bentuk pertunjukan kesenian Barongan yang tidak berkenaan dengan angka-angka. Penelitian yang bersifat deskriptif yaitu 
penelitian yang mendeskripsikan, menggambarkan hal yang berhubungan dengan keadaan (Moleong, 2001:11). Hasil penelitian dimaksudkan untuk mendeskripsikan data berupa kata-kata, gambar dan perilaku yang diamati.

Pendekatan penelitian yang digunakan merupakan pendekatan sosiologi, yaitu pendekatan yang memperhatikan lingkungan dalam masyarakat, yang melibatkan pendekatan individu dan interaksi. Pendekatan individu meliputi watak kemampuan psikomotorik yang mengerti tata kehidupan masyarakat. Pendekatan interaksi dan sosial mempengaruhi hubungan timbale balik antar individu dan masyarakat.

\subsection{Lokasi dan Sasaran Penelitian}

\subsubsection{Lokasi Penelitian}

Lokasi penelitian dilakukan di Dukuh Karang Rejo, Loram Kulon Kecamatan Jati Kabupaten Kudus Jawa Tengah. Penelitian pertama dalam penelitian ini mengambil lokasi di rumah Bapak Sukadi RT. 02 RW. I No. 47 selaku ketua dan pengelola grup kesenian Barongan Wahyu Budaya. Penelitian kedua di rumah Bapak Da’im RT. 02 RW. I No. 32 selaku penyedia tempat pelaksanaan pertunjukan Barongan Wahyu Budaya karena memiliki halaman yang cukup luas, lokasinya strategis berada dekat perempatan desa, serta bertepatan dengan berkumpulnya masyarakat yang menyaksikan pertunjukan Barongan.

Alasan peneliti mengambil penelitian di Dukuh Karang Rejo, Loram Kulon diawali dengan pertimbangan bahwa kesenian Barongan merupakan salah satu kesenian yang masih bertahan dan berkembang sampai sekarang dan masih digemari oleh masyarakat di daerah tersebut. 


\subsubsection{Sasaran Penelitian}

Sasaran utama dalam penelitian ini adalah bagaimana bentuk pertunjukan Barongan pada grup Wahyu Budaya di Dukuh Karang Rejo, Loram Kulon Kecamatan Jati Kabupaten Kudus .

\subsection{Teknik Pengumpulan Data}

Teknik pengumpulan data merupakan langkah yang paling strategis dalam penelitian, karena tujuan dari penelitian adalah mendapatkan data. Tanpa mengetahui teknik pengumpulan data, maka peneliti tidak akan mendapatkan data yang memnuhi standar data yang ditetapkan (Sugiyono, 2008:224). Pengumpulan data yang digunakan dalam penelitian ini adalah observasi, wawancara dan dokumentasi.

\subsubsection{Observasi}

Nasution (1988) dalam Sugiyono menyatakan bahwa, observasi adalah dasar semua ilmu pengetahuan. Para ilmuwan hanya dapat bekerja berdasarkan data, yaitu fakta mengenai dunia kenyataan yang diperoleh melalui observasi. Data itu dikumpulkan dan sering dengan bantuan berbagai alat yang sangat canggih, sehingga benda-benda yang sangat kecil maupun yang sangat jauh dapat diobservasi dengan jelas (Sugiyono, 2008:226).

Menurut Arikunto (1998:146) pengertian observasi adalah pengamatan yang meliputi perbuatan pemantauan terhadap suatu objek yang menggunakan seluruh indera atau pengamatan langsung. Observasi dalam penelitian ini menggunakan cara langsung terhadap observasi yang relevan dengan kondisi lingkungan di lokasi penelitian yang diamati. 
Tehnik pengumpulan data ini penulis mengadakan pengamatan terhadap kesenian Barongan Wahyu Budaya. Pelaksanaan observasi ini menggunakan tehniktehnik sebagai berikut:

\section{Observasi Langsung}

Observasi ini penulis mengadakan pengamatan secara langsung terhadap obyek penelitian terhadap obyek penelitian pada saat pementasan.

2. Observasi tidak Langsung

Penulis mengadakan pengamatan terhadap obyek penelitian dengan cara mengamati beberapa hasil rekaman yang berupa rekaman video dan foto.

\subsubsection{Wawancara}

Wawancara atau interview merupakan pertemuan dua orang untuk bertukar informasi dan ide melalui tanya jawab, sehingga dapat dikonstruksikan makna dalam suatu topik tertentu (Esterberg, 2002:231). Wawancara digunakan sebagai teknik pengumpulan data apabila peneliti ingin melakukan studi pendahuluan untuk menemukan permasalahan yang harus diteliti, tetapi juga apabila peneliti ingin mengetahui hal-hal dari responden yang lebih mendalam.

Wawancara terbagi menjadi tiga macam, yaitu (1) wawancara terstruktur, digunakan sebagai teknik pengumpulan data, bila peneliti telah mengetahui dengan pasti tentang informasi apa yang akan diperoleh. Oleh karena itu dalam melakukan wawancara, pengumpul data telah menyiapkan instrumen penelitian berupa pertanyaan-pertanyaan tertulis yang alternatif jawabannya pun telah disiapkan; (2) semiterstruktur, jenis wawancara ini sudah termasuk dalam kategori in-dept 
interview, di mana dalam pelaksanaannya lebih bebas bila dibandingkan dengan wawancara terstruktur; (3) tidak terstruktur, adalah wawancara yang bebas di mana peneliti tidak menggunakan pedoman wawancara yang telah tersusun secara sistematis dan lengkap untuk pengumpulan datanya (Sugiyanto, 2005: 233-234).

Peneliti melakukan wawancara dengan ketiga teknik yang telah dikemukakan oleh Sugiyanto. Pewawancara membawa pedoman atau daftar pertanyaan tentang hal yang akan diteliti. Langkah-langkah yang dilakukan dalam wawancara meliputi menentukan lokasi, menemukan informan yang akan dijadikan sumber informasi, menentukan waktu wawancara, membuat daftar pertanyaan yang akan diajukan kepada responden. Wawancara yang dilakukan dalam penelitian meliputi segala aspek tentang kesenian Barongan yang berhubungan dengan masyarakat.

Wawancara dilaksanakan dengan cara mengunjungi tempat sumber informasi, baik di lokasi pertunjukan, maupun di rumah. Wawancara diusahakan dapat berlangsung secara wajar dan tidak terlalu resmi, sehingga tidak menimbulkan suasana pembicaraan yang kaku. Wawancara difokuskan untuk menggali informasi tentang pertunjukan kesenian Barongan, dan juga guna menggali informasi tentang grup Wahyu Budaya serta masyarakat atau penonton. Wawancara ditujukan pada informan untuk menggali informasi, wawancara tersebut dilakukan kepada (1) pimpinan grup dengan maksud menggali informasi tentang asal usul kesenian Barongan, apa saja yang melatar belakangi subjek yang diteliti, properti apa saja yang dibutuhkan, serta perlengkapan apa saja yang diperlukan; (2) pemain atau penari untuk menggali informasi tentang para pemain, pengalaman; (3) masyarakat 
atau penonton untuk menggali informasi tentang pendapat masyarakat mengenai kesenian Barongan, sejauh mana masyarakat memahami makna yang terkandung dalam kesenian Barongan.

\subsubsection{Dokumentasi}

Dokumen merupakan catatan peristiwa yang sudah berlalu. Dokumen bisa berbentuk tulisan, gambar, atau karya-karya monumental dari seseorang. Dokumen yang berbentuk tulisan misalnya catatan harian, sejarah kehidupan (life histories), ceritera, biografi, peraturan, kebijakan. Dokumen yang berbentuk gambar, misalnya foto, gambar hidup, sketsa dan lain-lain. Dokumen yang berbentuk karya misalnya karya seni, yang dapat berupa gambar, patung, film, dan lain-lain (Sugiyono, 2004:329).

Dokumentasi adalah tehnik pengumpulan data yang berhubungan dengan dokumen baik dalam bentuk laporan, surat-surat resmi maupun catatan harian dan lain sebagainya. Teknik dokumentasi adalah teknik mencari data yang berkenaan dengan hal-hal atau veriabel yang berupa catatan, transkrip buku, surat kabar, majalah, prasasti, natulen rapat, agenda foto, dan sebagainya (Arikunto 2006:231).

Dokumentasi adalah pemberian atau pengumpulan bukti-bukti dan keterangan (seperti kutipan-kutipan dari surat kabar dan gambar-gambar) (Poerwadarminta, 2007). Dokumen yang diperoleh dari hasil penelitian yaitu berupa foto berlangsungnya pertunjukan Barongan dan catatan informasi dari informan yang berhubungan dengan objek penelitian, data statistik tentang Dukuh Karang Rejo, Loram Kulon Kecamatan Jati Kabupaten Kudus. 


\subsection{Teknik Keabsahan Data}

Langkah terakhir dari analisis data dalam penelitian yang dilakukan adalah verifikasi atau pemeriksaan keabsahan data. Uji keabsahan data dalam penelitian sering hanya ditekankan pada uji validitas dan reliabilitas. Dalam penelitian kualitatif, temuan atau data dapat dinyatakan valid apabila tidak ada perbedaan antara yang dilaporkan peneliti dengan apa yang sesungguhnya terjadi pada obyek yang diteliti. Menurut penelitian kualitatif, suatu realitas itu bersifat majemuk atau ganda, dinamis atau selalu berubah, sehingga tidak ada yang konsisten, dan berulang seperti semula. Heraclites dalam Nasution (1988) menyatakan bahwa "kita tidak bisa dua kali masuk sungai yang sama" Air mengalir terus, waktu terus berubah, situasi senantiasa berubah dan demikian pula perilaku manusia yang terlibat dalam situasi sosial. Dengan demikian tidak ada suatu data yang tetap, konsisten, stabil.

Uji keabsahan data dalam penelitian kualitatif meliputi uji, credibility (validitas internal), transferability (validitas eksternal), dependability (reliabilitas), dan confirmability (obyektivitas). Pemeriksaan keabsahan data juga dapat dilakukan dengan beberapa cara antara lain, yaitu teknik Triangulasi. Teknik inilah yang digunakan oleh peneliti untuk mendukung keabsahan data. Teknik Triangulasi adalah verifikasi penemuan melalui informasi dari berbagai sumber dalam pengumpulan data. Teknik ini meliputi tiga unsur penting dalam mendukung keabsahan data yaitu:

\section{Sumber}

Membandingkan dan mengecek balik derajat kepercayaan adanya informasi.

2. Metode 
Pengecekan derajat kepercayaan penemuan hasil penelitian dengan pengecekan derajat kepercayaan beberapa sumber data dengan metode yang sama.

\section{Teori}

Peneliti mengunakan beberapa sumber buku sebagai acuan teoritis, karena tidak mungkin peneliti hanya menggunakan satu teori untuk dapat memeriksa derajat kepercayaan suatu data informasi. Setelah memakai teori dari berbagai sumber selanjutnya peneliti menarik kesimpulan dengan menggunakan beberapa teori dan di dukung dengan data-data yang sudah ada.

\subsection{Teknik Analisis Data}

Analisis data adalah proses mencari dan menyusun secara sistematis data yang diperoleh dari hasil wawancara, catatan lapangan, dan dokumentasi dengan melakukan sintesa, menyusun ke dalam pola, memilih mana yang penting dan yang akan dipelajari, dan membuat kesimpulan sehingga mudah difahami oleh diri sendiri maupun orang lain (Sugiyono, 2008:244).

Proses analisis data dalam penelitian kualitatif dimulai dengan menelaah seluruh data yang tersedia dari berbagai sumber, yaitu wawancara dan pengamatan yang sudah tertulis dalam catatan lapangan, dokumen pribadi, dokumen resmi, gambar, foto dan sebagainya. Data tersebut sangat banyak, oleh sebab itu peneliti harus membaca dan mempelajarinya (Sumaryanto, 2007:105).

Milles dan Huberman (dalam Sugiyono 2008:249) menyatakan bahwa untuk memperoleh data yang benar, data yang diperoleh dengan melalui tehnik wawancara, observasi, dan dokumentasi kemudian direduksi, disajikan selanjutnya disimpulkan 
secara deskriptif. Data tersebut kemudian direduksi (disederhanakan), diklasifikasikan (kelompok), diinterpretasikan dan dideskripsikan kedalam bentuk bahasa verbal untuk mencari verifikasi (penarikan kesimpulan).

Proses analisa data dimulai dengan Pengumpulan data yaitu dengan menelaah seluruh data yang tersedia sebagai sumber, yang meliputi : wawancara, pengamatan yang sudah dituliskan dalam catatan lapangan, dokumentasi resmi, gambar dan foto. Proses reduksi (disederhanakan), dilakukan dengan cara penulis membuat rangkuman dari data yang sudah dikumpulkan. 


\section{BAB IV}

\section{HASIL PENELITIAN DAN PEMBAHASAN}

\subsection{Gambaran Umum Lokasi Penelitian}

\subsubsection{Lokasi dan Keadaan Geografis Desa Loram Kulon}

Lokasi penelitian tentang seni Barongan sebagai media interaksi simbolik antara pemain dengan penonton dilakukan di dukuh Karang Rejo, Loram Kulon Kecamatan Jati Kabupaten Kudus. Wilayah kecamatan Jati terletak pada ketinggian rata-rata 17 meter di atas permukaan laut. Beriklim tropis dan bertemperatur sedang.

Loram Kulon merupakan salah satu desa dari 14 desa yang menjadi bagian di kecamatan Jati. Di desa Loram terdapat peninggalan sejarah seperti makam ulama, gapura peninggalan Walisongo, dan gentong antik sepanjang 4 meter. Dalam bahasa Jawa, nama Loram Kulon berarti "Loram Barat". Menurut sejumlah sumber yang didapat dan dari beberapa literatur, Loram berasal dari pohon Lo (sebangsa kluwing) yang hanya ada satu-satunya di desa Loram. Pohon Lo dulu sering digunakan untuk bertapa oleh penguasa kerajaan Majapahit terakhir, Prabu Brawijaya. Setelah ratusan tahun kemudian, orang melihat pohon Lo tumbuh besar seperti raksasa serta masih berdiri kukuh. Warga desa tersebut melihat sesuatu yang ngeram-erami (mengherankan). Karena itu, kemudian mereka menyebutnya Lo dan Ram, sehingga lama-lama daerah itu dikenal dengan nama Loram. 


\section{PETA DESA LORAM KULON}

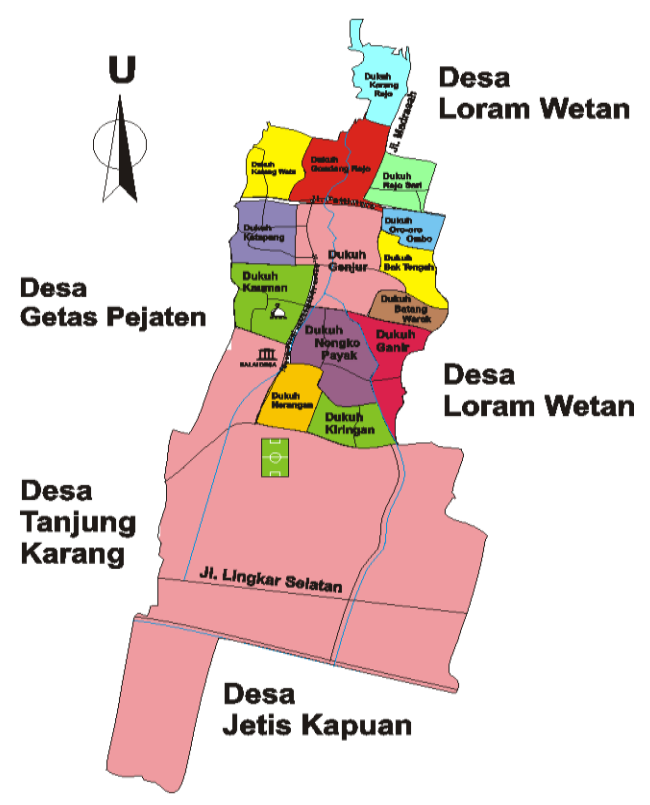

Foto 4.1 Peta Desa Loram Kulon

(Sumber : Andeslo, Januari 2012)

Desa Loram kulon memiliki luas wilayah $196,22 \mathrm{ha} / \mathrm{m}^{2}$, sebagian besar wilayahnya adalah bangunan atau pemukiman penduduk karena sampai saat ini Desa Loram terkenal sebagai kawasan home industri mulai dari tas sampai tekstil. Salah satu produk terkenal dari Loram adalah Bandeng Presto Pak Kumis. Wilayah Desa Loram Kulon memiliki batasan-batasan desa yaitu, sebelah Utara adalah Desa Getas Pejaten dan Loram Wetan, sebelah Selatan adalah Desa Jetis Kapuan, sebelah Timur adalah Desa Loram Wetan, dan sebelah Barat adalah Desa Getas Pejaten dan Tanjung Karang. Desa Loram Kulon memiliki suhu rata-rata 30-31 derajat celcius dengan lahan persawahan yang mulai menyempit akibat pembangunan tempat industri baik pabrik maupun rumahan. 


\subsubsection{Kependudukan}

Penduduk Desa Loram Kulon, menurut data yang tercatat sampai bulan Desember 2015, berjumlah 11.792 jiwa yang terdiri dari penduduk laki-laki 5.190 jiwa dan penduduk perempuan 6.602 jiwa. Adapun tabelnya adalah sebagai berikut :

\section{Tabel 4.1 Keadaan Penduduk Desa Loram Kulon}

\begin{tabular}{|c|c|c|}
\hline No & Kelompok Umur & Jumlah \\
\hline 1 & $0-14$ tahun & 2.952 jiwa \\
2 & 15-64 tahun & 7.821 jiwa \\
3 & 65 tahun keatas & 1.019 jiwa \\
\hline \multicolumn{2}{|r|}{ Jumlah } & 11.792 jiwa \\
\hline
\end{tabular}

Sumber : Monografi Desa Loram Kulon bulan Desember 2015

Komposisi penduduk pada tabel 4.1 menunjukkan bahwa sebagian besar masyarakat desa Loram Kulon mempunyai persentase jumlah penduduk tertinggi ada pada kelompok usia 15-64 tahun, yaitu sebanyak 7.821 jiwa, sedangkan untuk persentase jumlah penduduk terendah adalah pada kelompok usia 65 tahun ke atas, yaitu sebanyak 1.019 jiwa. Dari rata-rata usia produktif 15-64 tahun adalah mereka yang memiliki peran dalam melestarikan kesenian Barongan. Yang berkecimpung di dalam dunia seni khususnya kelompok kesenian Wahyu Budaya ada sekitar kurang lebih 15-20 orang mulai dari umur 20 tahun sampai 60 tahun.

\subsubsection{Mata Pencaharian}

Penduduk Desa Loram Kulon memiliki mata pencaharian yang bermacammacam. Sampai dengan bulan Desember 2015, jumlah orang yang mempunyai 
pekerjaan sebanyak 8.947 orang. Adapun data jenis pekerjaan pada Desa Loram Kulon sampai dengan bulan Desember 2015 adalah sebagai berikut :

Tabel 4.2 : Data Mata Pencaharian Desa Loram Kulon

\begin{tabular}{|c|l|l|}
\hline No & Jenis Pekerjaan & Jumlah \\
\hline 1 & Buruh Tani & 472 orang \\
2 & Petani & 204 orang \\
3 & PNS/TNI/POLRI & 198 orang \\
4 & Buruh / Swasta & 7.208 orang \\
5 & Pedagang & 385 orang \\
6 & Montir & 19 orang \\
7 & Purnawirawan / pensiunan & 35 orang \\
8 & Lainnya & 219 orang \\
\hline
\end{tabular}

Sumber : Monografi Desa Loram Kulon bulan Desember 2015

Penduduk Desa Loram Kulon sebagian besar memperoleh penghasilan dari bekerja di PT dan home industry sebagai buruh. Hal ini dikarenakan desa Loram sangat terkenal dengan berbagai macam hasil karya rumahan, beberapa contoh diantaranya adalah kerajinan anyaman bambu, tas, kuliner Bandeng Presto, konveksi, plastik, mainan serta alat rumah tangga. Industri kerajinan tas asal Desa Loram Kulon ini sudah mecapai pasar di luar daerah dengan kualitas yang tidak kalah dari barang aslinya. Berdasarkan monografi Desa Loram Kulon tahun 2015 menunjukkan 
sebagian besar masyarakat Desa Loram Kulon bekerja sebagai buruh atau karyawan pabrik. Dari hasil wawancara para pemain Barongan Wahyu Budaya, rata-rata para pemain Barongan kelompok Wahyu Budaya bermata pencaharian sebagai buruh.

\subsubsection{Kehidupan Keagamaan}

Sebagian besar penduduk Desa Pasuruhan Lor beragama Islam. Ada juga pemeluk agama Kristen dan Katolik. Tetapi perbedaan agama dan kepercayaan tetap menjadikan masing-masing individu dapat hidup rukun dan berkembang bersamasama. Hal ini dapat dibuktikan dari adanya kerjasama dan gotong-royong antar umat beragama, baik dalam pemerintahan maupun sosial masyarakat lainnya.

Dahulunya masyarakat Loram masih kental dengan agama Hindu dan Budha hingga akhirnya ada pemuka agama yang menyebarkan Islam di daerah selatan Kudus, dan hingga saat ini agama Islam-lah yang akhirnya dianut oleh masyarakat Loram. Seluruh anggota kelompok kesenian Barongan Wahyu Budaya mulai dari pembarong, pemusik, dan pemain kuda lumping adalah pemeluk Agama Islam.

Adapun data pemeluk agama di Desa Loram Kulon sampai dengan bulan Desember 2015 adalah sebagai berikut:

Tabel 4.3 Data Pemeluk Agama Desa Loram Kulon

\begin{tabular}{|c|c|c|}
\hline No & Agama & Jumlah Penduduk \\
\hline & Islam & 11.562 orang \\
2 & Kristen & 82 orang \\
3 & Katolik & 148 orang \\
\hline
\end{tabular}

Sumber : Monografi Desa Loram Kulon bulan Desember 2015 


\subsubsection{Pendidikan}

Pendidikan merupakan cara untuk mencerdaskan kehidupan bangsa. Pendidikan dapat dijadikan tolak ukur atau indikator kualitas penduduk. Semakin tinggi kualitas pendidikan yang ditempuh, maka semakin tinggi pula kualitas penduduk. Penduduk Desa Loram Kulon termasuk penduduk yang sudah terlepas dari tiga buta meskipun masih banyak masyarakat Desa Loram Kulon hanya menyelesaikan pendidikan hingga tamat SMP.

Tingkat pendidikan warga Loram Kulon dapat dilihat pada tabel berikut :

Tabel 4.4 Jumlah penduduk Desa Loram Kulon berdasarkan Pendidikan

\begin{tabular}{|l|l|l|}
\hline No & Pendidikan & Jumlah Penduduk \\
\hline 1 & Belum sekolah & 984 orang \\
3 & Tidak tamat SD & 76 orang \\
4 & Tamat SD/sederajat & 3.578 orang \\
5 & Tamat SMP/sederajat & 3.816 orang \\
6 & Tamat SMA/sederajat & 2.731 orang \\
7 & Tamat Diploma 1-2 & 306 orang \\
8 & Tamat Diploma 3 & 141 orang \\
9 & Tamat S 1 & 154 orang \\
\hline
\end{tabular}

Sumber : Monografi Desa Loram Kulon bulan Desember 2015 
Tabel 4.4 di atas merupakan data penduduk Loram Kulon dihitung dari status pendidikan. Jumlah terbanyak adalah tamat SMP/sederajat dengan perhitungan 3.816 orang. Sedangan pada jumlah terkecil ada pada masyarakat yang lulus dari pendidikan S2 yang hanya 6 orang saja. Jumlah terkecil kedua adalah warga yang tidak tamat SD dengan jumlah 76 orang namun beberapa dari mereka banyak yang mengikuti kursus-kursus ketrampilan seperti kursus menjahit, perbengkelan, bordir dan lain sebagainya. Pendukung dari kelompok kesenian Barongan Wahyu Budaya pada umumnya menempuh pendidikan hanya sampai tamat SMP, namun ada juga beberapa yang sedang menempuh jenjang S1.

\subsection{Potensi Kesenian dan Budaya di Desa Loram Kulon}

Loram kulon merupakan desa yang memiliki banyak sekali kesenian dan budaya yang sudah menjadi tradisi serta ciri khas yang dimiliki oleh Kota Kudus. Meskipun sebagian besar penduduknya bermatapencaharian sebagai buruh, namun dalam hal seni, masyarakat desa Loram Kulon memiliki semangat yang tinggi untuk terus berkarya dan berpartisipasi dalam berkesenian. Ada beberapa kesenian yang sampai saat ini masih berkembang, diantaranya yaitu: kesenian terbang papat atau yang biasa disebut terbangan, ketoprak, tari kretek, kuda lumping dan Barongan.

\subsubsection{Kesenian Terbang Papat}

Terbang papat adalah kesenian yang beranggotakan empat penabuh rebana dan satu penabuh bedug. Perkembangan dunia saat ini tidak dapat dilepaskan dari pengaruh arus globalisasi yang berdampak signifikan terhadap ekstensi kesenian tradisional. 


\subsubsection{Ketoprak}

Eksistensi kesenian ketoprak di Kudus memang tidak begitu merakyat seperti yang terdapat di kota lain misalnya Pati, Rembang dan Blora. Namun keberadaannya masih diakui dan cukup banyak berkembang di Kudus terutama di Desa Loram Kulon.

\subsubsection{Tari Kretek}

Tari Kretek merupakan tarian khas Kota Kudus yang diciptakan oleh seniman Endang pemilik sanggar seni Puring Sari dan popular sejak tahun 1985. Tari Kretek diciptakan karena Kudus merupakan salah satu kota di Jawa Tengah yang identik dengan industri rokok kretek.

\subsubsection{Kuda Lumping dan Barongan}

Kesenian Kuda Lumping di Kudus sering disebut dengan nama kesenian Jaran Dor. Kesenian Jaran Dor merupakan bagian dari atraksi Kuda Lumping atau Jaran Kepang. Namun kesenian Jaran Dor yang terdapat di Kudus terutama di Desa Loram Kulon berbeda dengan atraksi Kuda Lumping yang lain. Hal ini dikarenakan Jaran Dor yang ada di Kudus berkembang sesuai dengan versi perkumpulan Paseban Agung Kudus. Versi Paseban Agung Kudus atraksinya sudah tidak lagi menggunakan orang-orang kesurupan lagi, tetapi menggunakan kekuatan magis dari aura alami dan hasilnya menjadi semacam debus.

Atraksi Jaran Dor dapat dikatakan sulit untuk dipisahkan dengan kesenian Barongan. Namun dalam pementasan Barongan, Jaran Dor bisa saja tidak digunakan akan tetapi diganti dengan pertunjukan Kuda Lumping biasa yang berfungsi sebagai 
pengiring pertunjukan Barongan. Biasanya atraksi Jaran Dor dilakukan setelah pertunjukan Barongan selesai. Adapun atraksi yang dilakukan diantaranya: makan silet, makan semprong kaca, makan paku besi, dipecut menggunakan bambu dan yang terakhir adalah lidah serta tubuh dari pemain ditusuk memakai jarum atau besi runcing.

Menurut pengamatan, dari semua kesenian yang tumbuh di Desa Loram Kulon dapat dikelompokkan menjadi dua berdasarkan masyarakat pendukungnya. Terbang papat disebut kesenian orang dewasa karena sebagian besar penggemarnya adalah dari kalangan orang tua. Sedangkan kesenian Barongan, Kuda Lumping dan Tari Kretek disebut kesenian campuran karena pendukungnya dari semua kalangan, dari anak-anak, orang tua dan anak muda.

Dari berbagai macam seni yang tumbuh di Desa Loram Kulon, kesenian Barongan sangat digemari oleh masyarakat desa khususnya di Desa Loram Kulon. Dalam perkembangannya, kesenian Barongan banyak mengalami perkembangan. Sekarang selain orang tua, anak-anak muda pun banyak yang tertarik dengan kesenian ini buktinya setiap ada pertunjukan Barongan banyak yang ikut bergabung di tempat pementasan Barongan. Grup kesenian Barongan Wahyu Budaya di Dukuh Karang Rejo Desa Loram Kulon cukup terkenal di Kecamatan Jati.

Desa Loram Kulon selain memiliki berbagai macam kesenian juga memiliki budaya khas yang tidak dimiliki oleh desa lain di Kudus, diantaranya adalah gapura Masjid Wali, tradisi sego kepel, ampyang maulid dan tradisi kirab pengantin. 


\subsubsection{Gapura Masjid Wali}

Masjid Wali terletak di Desa Loram Kulon, kecamatan Jati, kabupaten Kudus yang memiliki nama asli Masjid AT-TAQWA. Dibangun oleh Tjie Wie Gwan yang merupakan menantu dari Sunan Kudus.

\subsubsection{Tradisi Sego Kepel}

Sego Kepel atau dalam bahasa Indonesia berarti nasi kepel merupakan budaya atau tradisi yang sampai sekarang masih berlaku. Sego kepel adalah nasi putih yang dibungkus menggunakan daun pisang berbentuk bulat dan diikat di bagian atasnya. Lauknya sangat sederhana, hanya pepes tahu atau bisa diganti dengan bothok.

Menurut hasil wawancara tidak terstruktur peneliti kepada Bapak Suprianto (38 tahun) yang merupakan warga asli Loram Kulon namun sekarang menetap di Desa Peganjaran karena telah menikah, beliau mengatakan dengan bahasa dan logat Kudus yang khas:

Ndek jamane aku cilik, saben dino moro ning Masjid Wali ngaji bareng-bareng supoyo iso keduman sego kepel. Ogak reti iku sego sing menehi sopo, tujuane opo. Bareng aku wis sekolah TBS lagi mudeng nek sego kepel iku asline ndek iko ajaran teko sultan sing mbahurekso ngloram kanggo sodaqoh. Dadi mbendino mesti ono sing ngeteri rono.

(Dahulu jaman saya masih kecil, setiap hari datang ke Masjid Wali untuk mengaji bersama-sama agar mendapat bagian nasi kepel. Tidak tahu nasi itu pemberian dari siapa dan bertujuan untuk apa. Setelah saya sekolah di TBS baru paham kalau nasi kepel itu dahulunya ajaran dari Sultan yang berkuasa di Loram untuk niat sedekah. Jadi setiap hari ada yang datang mengantarkan nasi kepel kesana). 


\subsubsection{Ampyang Maulid}

Ampyang Maulid adalah perayaan masyarakat Loram Kulon yang digunakan untuk memperingati Maulid atau kelahiran Nabi Muhammad SAW di Masjid Wali Loram Kulon. Ampyang adalah tandu yang berisi nasi kepel yang dirangkai mirip gunungan setinggi 1,5 meter.

\subsubsection{Tradisi Kirab Pengantin}

Tradisi Kirab Pengantin atau Nganten Mubeng di Masjid Wali. Tradisi Kirab Pengantin mewajibkan setiap pasangan pengantin yang menikah pada hari itu harus melewati pintu Barat dan Timur masjid yang berupa gapura batu bata merah, kegiatan Kirab Pengantin dilakukan setelah mempelai selesai melaksanakan prosesi ijab qabul. Apabila sudah mengelilingi gapura maka pengantin akan didoakan di depan Masjid Wali dan disaksikan oleh warga setempat.

Angger ono sing dadi kemanten entuk bojo wong ngloram yo kudune mubeng masjid wong ancen adate kawit ndek iko ngono. Wis dadi ciri khas wong kono. Tujuane supoyo kene sing lagi membina rumah tangga baru iku iso eling karo sing Kuoso. (Setiap ada yang menjadi pengantin dan mendapat pasangan orang Loram harus mengelilingi masjid karena memang adatnya dari dulu seperti itu. Sudah menjadi ciri khas orang sana. Tujuannya supaya kita yang baru saja membina rumah tangga dapat selalu ingat kepada Yang Kuasa).

\subsection{Kesenian Barongan di Desa Loram Kulon}

Kesenian dan budaya yang tersebar di setiap daerah tentunya memiliki sejarah tersendiri. Sejarah menyebarnya kesenian Barongan di Kudus dapat dikaitkan dengan 
kondisi penduduk dan keagamaannya yang dapat digolongkan dalam kota santri. Terbukti di Kudus banyak terdapat pondok pesantren, sekolah dengan jurusan agama Islam serta beberapa tempat ibadah peninggalan Wali Songo, mengingat di Kudus sendiri memiliki dua Wali dari Sembilan Wali penyebar agama Islam yang dikenal luas oleh masyarakat terutama oleh penganut agama Islam. Kedua Wali tersebut adalah Sunan Kudus dan Sunan Muria yang dalam penyebaran Agama Islam dahulu selalu menggunakan media-media seni untuk menarik minat masyarakat.

Kesenian Barongan tidak terlepas dari peran Sunan Muria yang memiliki banyak pengikut, salah satunya yaitu Mbah Barong. Mbah Barong adalah seorang santri Sunan Muria yang mendapat perintah dari Sunan Muria untuk mengamalkan ilmu dan menanamkan nilai-nilai agama Islam di sekitar Kudus. Akhirnya dengan restu Sunan Muria, Mbah Barong mendirikan sebuah pondok pesantren di tengah kota. Di pondok pesantren itulah, Mbah Barong mulai mengajarkan ilmu Agama Islam dan mengembangkan kesenian lokal mirip Barongsai namun lebih sederhana, kesenian tersebut diberi nama Barongan.

Kesenian Barongan yang diajarkan oleh Mbah Barong santer terdengar oleh beberapa pemuka agama pada saat itu sehingga banyak tokoh-tokoh agama yang ikut mempelajari, diantaranya adalah Ki Gedhe Loram dan Ki Gedhe Getas. Ki Gedhe Loram dan Ki Gedhe Getas menggunakan media seni Barongan untuk mengajarkan nilai-nilai agama Islam di Desa Loram dan sekitarnya.

Berdasarkan informasi dari Bapak Karmin (59 tahun) sebagai Pawang Barong Grup Wahyu Budaya, kurang tahu pasti ada pada tahun berapa namun yang menjadi 
sejarah adanya kesenian Barongan di Loram adalah Ki Gedhe Loram pada zaman Majapahit. Nama aslinya Ronggo Warsito, beliau adalah tokoh agama yang mengajarkan Agama Islam menggunakan seni, sama seperti Sunan Kudus dan Sunan Muria yang sering menyebarkan Agama Islam melalui lantunan-lantunan rohani berupa sholawatan.

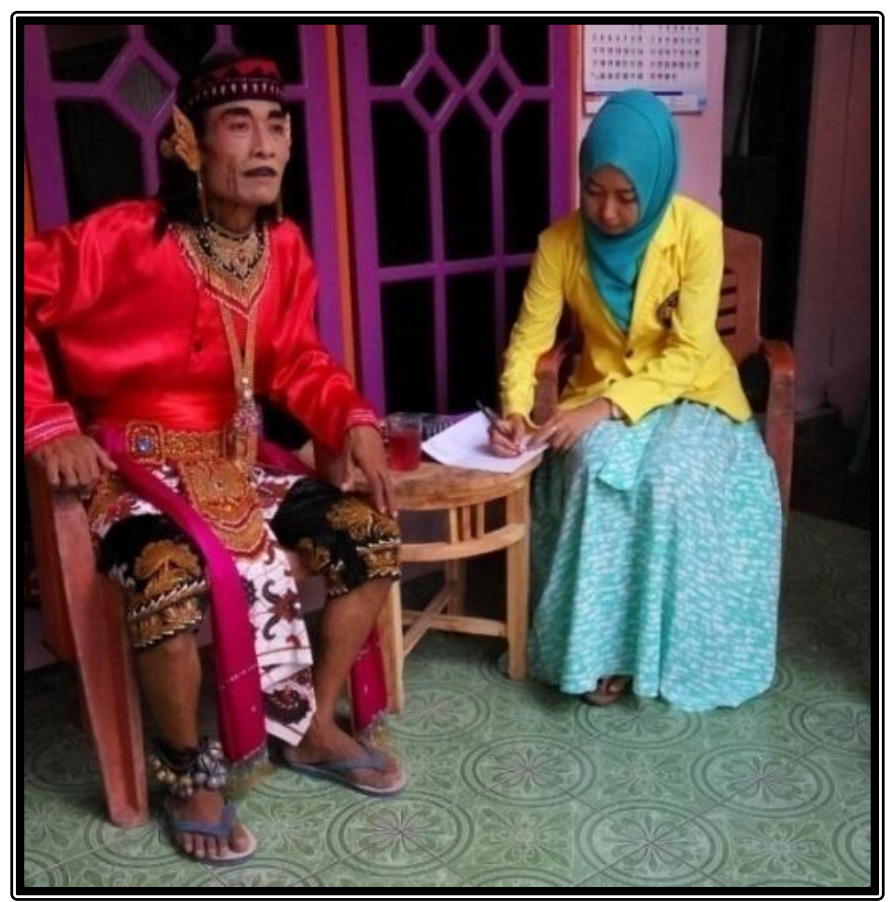

Foto 4.2 Wawancara dengan Bapak Karmin (Pawang Barong) (Dokumentasi: Abrilia, April 2016)

Wawancara dengan Bapak Sukadi (52 tahun) selaku pemilik dan ketua grup Wahyu Budaya pada April 2016.

Barongan teko ngloram ku akeh sing duwe nduk, tapi yo pemaine pethilan. Kadang main rono, kadang yo melu main rene. Nek pas ono tanggapan sopo sing lego yo tak kon mangkati. Iki miturut sejarah sing wis ono, Barongan Kudus asale teko crito Singo Barong, jenenge Gembong Kamijoyo sing wujudte ku koyo macan. Oleh perintah teko Raja Mataram kon ngluru penthul karo tembem. Akhire ketemu terus perang, peperangan dimenangno 
penthul tembem. Paling kerep ono tanggapan iku pas ono cah sunat karo pitulasan.

(Barongan dari Desa Loram itu banyak, tapi pemainnya diambil dari sana-sini. Kadang main di sana, kadang juga ikut main di sini. Kalau kebetulan ada tanggapan siapa yang sedang tidak ada pekerjaan ya saya suruh untuk memainkan. Ini menurut sejarah yang sudah ada, Barongan Kudus berawal dari cerita Singa Barong, namanya Gembong Kamijoyo yang berwujud seperti macan. Mendapat perintah dari Raja Mataram untuk mencari Penthul dan Tembem. Akhirnya mereka bertemu dan terjadi peperangan. Peperangan dimenangkan oleh Penthul Tembem. Paling sering ada tanggapan itu saat ada anak yang khitanan dan acara tujuhbelasan).

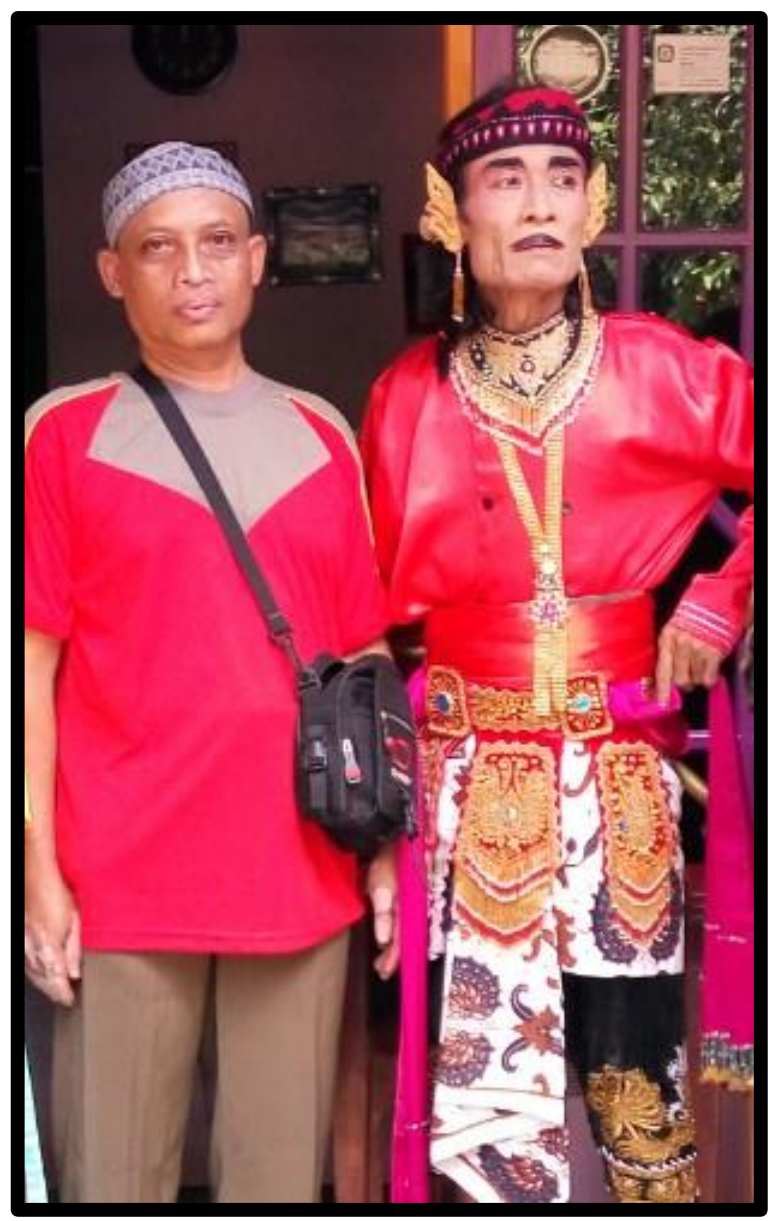

Foto 4.3 Bapak Sukadi (Ketua Grup) dan Bapak Karmin (Pawang Barong) (Dokumentasi: Abrilia, April 2016) 
Barongan diyakini sebagai wujud penjelmaan dari Sang Bhatara Kala. Barongan adalah Singo Barong yang dijuluki dengan nama Gembong Kamijoyo. Gembong Kamijoyo merupakan anak dari Dewi Partinah namun sejak kecil diasuh oleh Mbok Rondho Dhadapan di hutan Lodoyo. Gembong Kamijoyo berwujud menyerupai macan yang berperawakan besar berbulu loreng dan mempunyai keistimewaan dapat berbicara seperti manusia serta mempunyai kesaktian.

Gembong Kamijoyo menjadi raja hutan di seluruh tanah Jawa, sehingga diperbolehkan makan apa saja yang sedianya menjadi jatah Bhatara Kala. Kesaktian Gembong Kamijoyo akhirnya terdengar sampai ke telinga Raden Prabu Brawidjaya di Majapahit sehingga menyuruh seorang prajurit untuk memanggil Gembong Kamijoyo guna membuktikan kesaktiannya. Karena kesaktian itu telah ditunjukan kepada Prabu Brawidjaya, sehingga Gembong Kamijoyo mendapat tugas untuk mencari dua orang cemaniloka, yang telah mengajarkan ilmu agama suci di tanah Jawa secara diam-diam tanpa ijin dari Raden Prabu Brawidjaya terlebih dahulu.

Puluhan tahun Gembong Kamijoyo keluar masuk hutan di seluruh Jawa tetapi tidak juga menemukan dua orang yang dicari. Hingga akhirnya tibalah Gembong Kamijoyo di hutan Patiayam yang terletak di lereng sebelah timur Gunung Muria, di sana Gembong Kamijoyo bertemu dengan Penthul dan Tembem yang tidak lain adalah cemaniloka yang dicarinya. Maka terjadilah perang antara Gembong Kamijoyo melawan Penthul dan Tembem. Ternyata kesaktian Penthul dan Tembem sangat luar biasa sehingga Gembong Kamijoyo dapat dikalahkan dan ditundukkan dengan diberi air bening serta asap dupa. 
Atas kemurahan hati Penthul dan Tembem, permohonan Gembong Kamijoyo untuk dibebaskan dipenuhi asal Gembong Kamijoyo sanggup memenuhi perintah Penthul dan Tembem. Perintah Penthul dan Tembem itu adalah:

1. Gembong Kamijoyo dilarang makan manusia yang menjadi jatah Bathara Kala apabila manusia tersebut mau member pengganti berupa upacara ruwatan untuk anak yang Ontang-Anting, Sendang Kapit Pancuran, Pancuran Kapit Sendang.

2. Gembong Kamijoyo dilarang memakan sembarang hewan yang membantu petani seperti sapi, kerbau, ayam, itik, kambing dan sebagainya.

Mulai saat itulah agama suci yang tidak lain adalah agama Islam mulai sedikit demi sedikit disiarkan di tanah Jawa. Dahulunya pertunjukan Barongan berdurasi antara 7-8 jam, namun sekarang lebih dipersingkat waktunya menjadi beberapa jam saja. Walaupun begitu antusias warga masih sangat terlihat karena biar bagaimanapun kesenian Barongan merupakan warisan budaya yang memiliki banyak makna di dalamnya.

Bapak Sukadi menjelaskan asal mula terbentuknya Grup Wahyu Budaya pada tahun 1995, bermula dari keinginannya untuk melestarikan kesenian Barongan di Loram Kulon. Namun tidak hanya itu, Bapak Sukadi juga berusaha memberikan pekerjaan kepada anak-anak di Loram Kulon yang putus sekolah. Wahyu Budaya diambil dari nama salah seorang anak Bapak Sukadi tetapi juga memiliki makna agar selalu mendapat petunjuk dan lindungan dari Yang Maha Kuasa.

Atiku krenteg nek ngeti cah cilik-cilik do ora gelem sekolah nduk. Ngono iku terus ape dadi opo. Tahun 80-an sebenere wis akeh sing 
duwe grup Barongan ning Loram Kulon. Tapi aku durung kepikiran pengen duwe grup dewe. Naliko semono ijeh seneng melu main ngalor ngidul. Akhire tahun 95 gawe grup tujuanku ben cah-cah sing pengangguran duwe pekerjaan rak ketang main nek pas ono tanggapan tok. Saiki yo wis do kerjo bocahe, disuluri nom-noman. Anakku Wahyu nek pas prei mbogae yo melu main. Mulane grup iki tak wek'i jeneng Wahyu Budaya, sing pertama tak jukukno jenenge anakku, sing kedua mugo-mugo grup iki oleh berkah soko pengeran.

(Saya miris melihat anak-anak kecil tidak mau sekolah. Seperti itu terus mau jadi apa. Tahun 80-an sebenarnya sudah banyak yang membentuk grup Barongan di Loram Kulon. Tapi saya belum berpikiran untuk mendirikan grup sendiri. Waktu itu masih senang ikut pentas kesana kemari. Akhirnya pada tahun 95 membentuk grup sendiri, tujuan saya supaya anak-anak pengangguran di sini punya pekerjaan walaupun hanya saat ada tanggapan saja. Sekarang anakanak itu sudah bekerja, diteruskan anak-anak yang lebih muda. Anak saya, Wahyu, kalau libur kerja juga ikut main. Makanya grup ini saya beri nama Wahyu Budaya, yang pertama saya ambil dari nama anak saya, yang kedua harapannya semoga grup ini selalu mendapat berkah dari Yang Kuasa).

\subsection{Bentuk Pertunjukan Kesenian Barongan Wahyu Budaya}

Bentuk pertunjukan seni merupakan rangkaian karya seni yang disajikan atau dihidangkan secara menyeluruh dari awal sampai akhir sesuai dengan struktur pertunjukan. Batasan tentang struktur pertunjukan kesenian Barongan dalam tulisan ini mengacu pada pendapat Djelantik (1999:37) yang mengatakan bahwa struktur atau susunan dari karya seni adalah aspek yang menyangkut keseluruhan dari karya seni itu dan meliputi juga peranan masing-masing bagian dalam keseluruhan itu.

Kesenian Barongan Wahyu Budaya terdiri dari 19 orang dengan peran yang berbeda, antara lain 4 orang pembarong, 8 orang pengiring, 1 orang Penthul, 1 orang Bondet dan 5 orang pemain kuda lumping. Penthul merupakan pimpinan atau pawang Barong yang digambarkan sebagai tokoh keras namun membela kebenaran. 
Pembahasan mengenai bentuk pertunjukan kesenian Barongan mengarah pada elemen-elemen pertunjukan dan urutan penyajian. Elemen-elemen pertunjukan meliputi:

\subsubsection{Gerak}

Gerak dibagi menjadi dua yaitu gerak murni dan gerak maknawi. Gerak murni merupakan gerak yang tidak mengandung arti, sedangkan gerak maknawi merupakan gerak yang memiliki makna atau arti. Pada kesenian Barongan Wahyu Budaya hampir keseluruhan dari gerak yang dimainkan adalah gerak maknawi. Gerakan yang digunakan sangat sederhana namun mudah dipahami. Secara keseluruhan ragam gerak kesenian Barongan Wahyu Budaya dapat dideskripsikan sebagai berikut:

\subsubsection{Gerakan Pawang (Penthul)}

Gerakan-gerakan Penthul sangat sedarhana. Hanya menggunakan beberapa ragam gerak yang monoton seperti gedrug, klebatan sampur, tepisan, klepatan dan pancalan. Selain beberapa gerakan tersebut, Penthul juga menyisipkan gerakan patah-patah sebagai simbol dari sifat tegas dan gagah. Karakter dari Penthul dalam cerita seni Barongan melambangkan kesederhanaan, kasar, keras, berani namun dilandasi dengan kebenaran.

\subsubsection{Gedrug}

Gerakan gedrug merupakan gerakan yang dilakukan Penthul saat mulai memasuki arena pementasan. Gedrug adalah gerakan kaki yang terpusat pada hentakan telapak kaki kanan yang menghentak bumi sebagai pelambang kesadaran manusia atas daya hidup yang ada di bumi, bahwa bumi sebagai sumber kehidupan 
yang perlu dipahami adanya. Gedrug dalam sebuah tarian memiliki makna manusia mulai mengenal bumi tempat di mana dilahirkan dan bertahan hidup.

Iringan musik yang mulai mengalun menjadi pertanda pertunjukan segera dimulai. Setelah beberapa menit kemudian Penthul memasuki arena pertunjukan dengan berjalan biasa menuju tengah arena pertunjukan. Kemudian Penthul mulai bergerak menari sederhana mengibaskan sampur, berjalan memutar dengan sesekali menghentak-hentakkan salah satu kaki ke tanah.

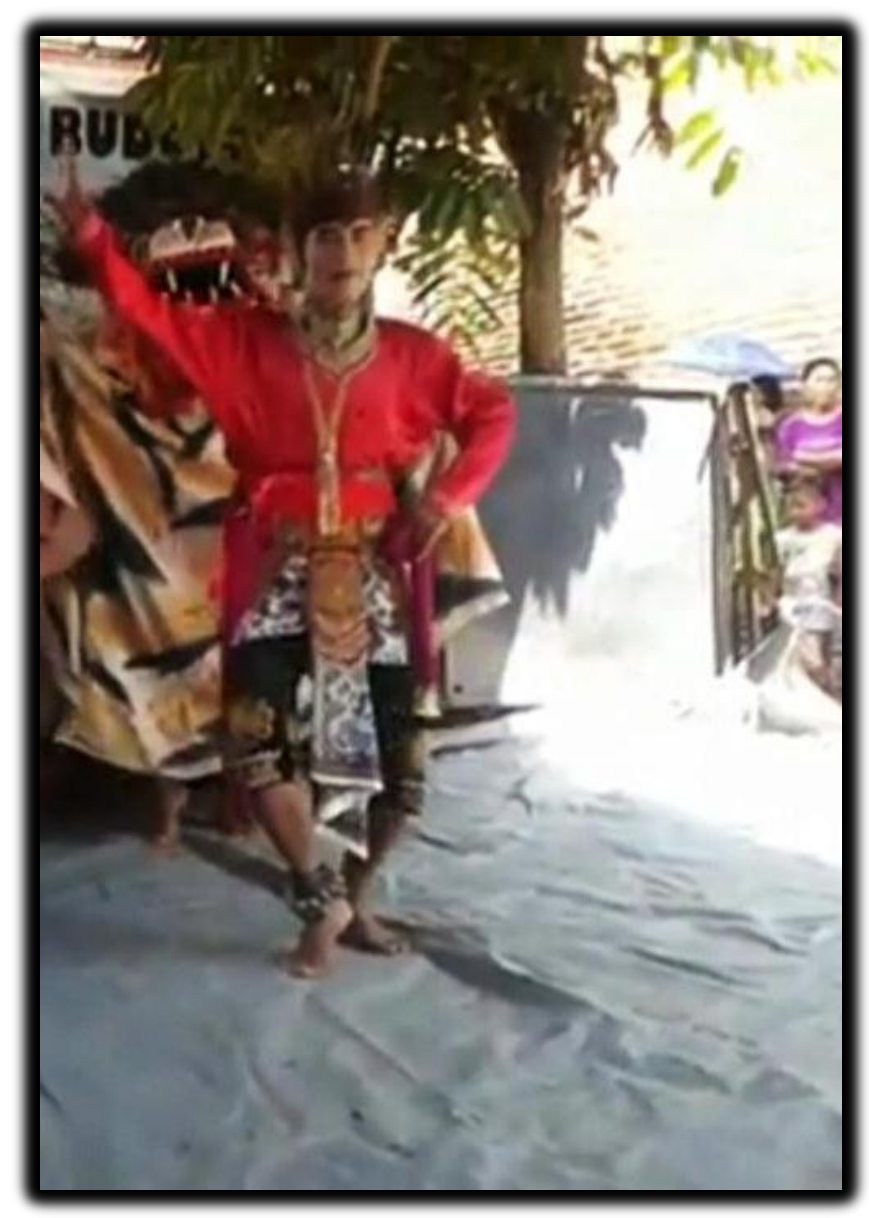

Foto 4.4 Gedrug

(Dokumentasi: Abrilia, April 2016) 


\subsubsection{Klebatan Sampur}

Klebatan sampur adalah gerakan mengibaskan sampur yang diikatkan pada pinggang Penthul. Klebatan sampur bermakna sebagai perlindungan diri karena sampur yang digunakan Penthul dalam Kesenian Barongan memiliki makna sebagai alat untuk menjauhkan diri dari segala pengaruh buruk. Pada saat Penthul masih menari, Barongan mulai memasuki arena pementasan kemudian menari bersama Penthul. Gerakan klebatan sampur dapat dilihat pada foto 4.5

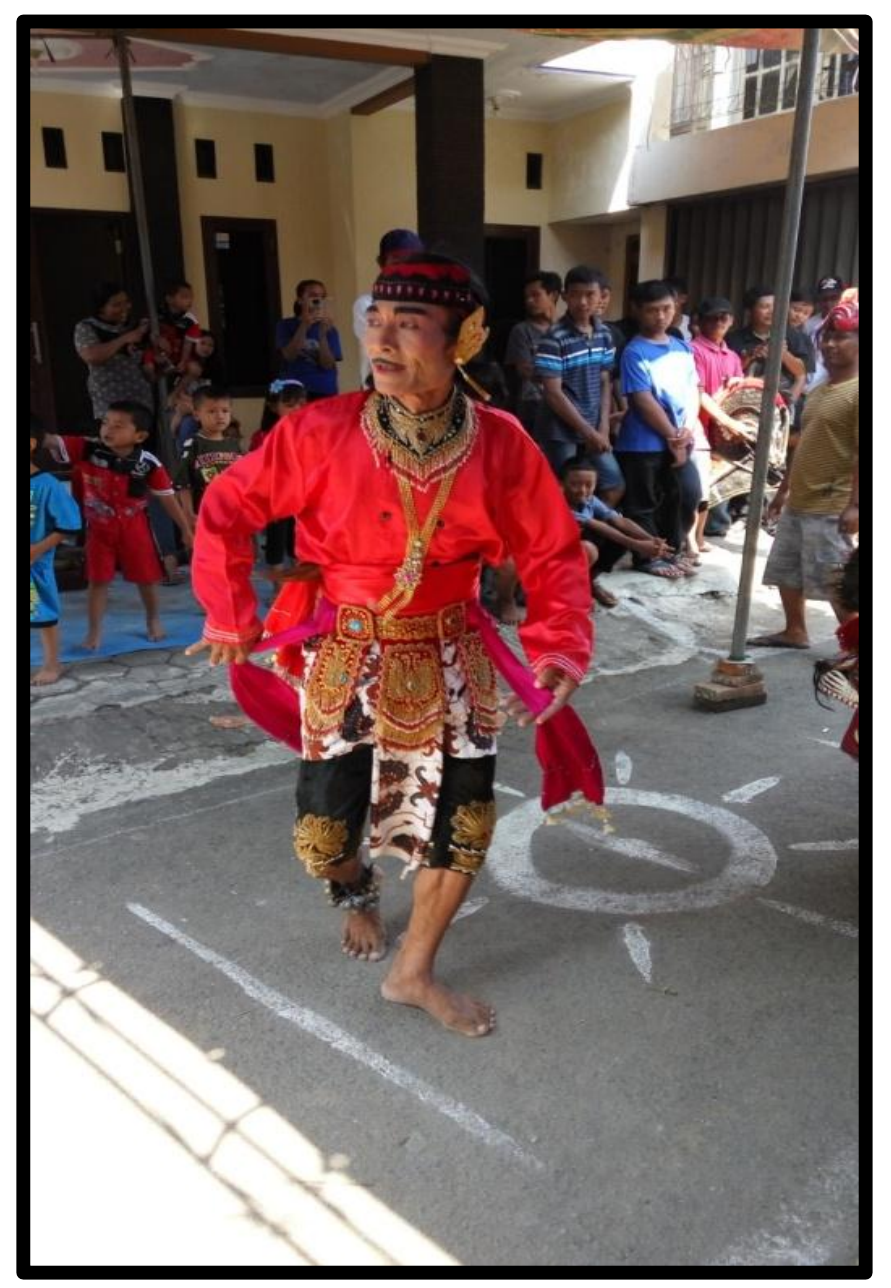

Foto 4.5 Penthul melakukan gerakan klebatan sampur (Dokumentasi: Abrilia, April 2016) 


\subsubsection{Tepisan}

Tepisan merupakan simbol dari gerakan kecekatan tangan dalam melindungi tubuh dari unsur negatif. Bapak Karmin (Penthul) melakukannya saat Barongan bergerak menyerangnya. gerakan tepisan sangat nyata dengan mudah dipahami oleh penonton, penonton dapat mengartikan bahwa adegan tersebut dilakukan Penthul sebagai perlindungan diri dengan cara menepis serangan Barongan. Kaki Penthul membentuk kuda-kuda, kemudian tangan kanan memegang sampur, sedangkan tangan kiri berada di depan wajah hingga dada untuk melindungi diri dari serangan Barongan.

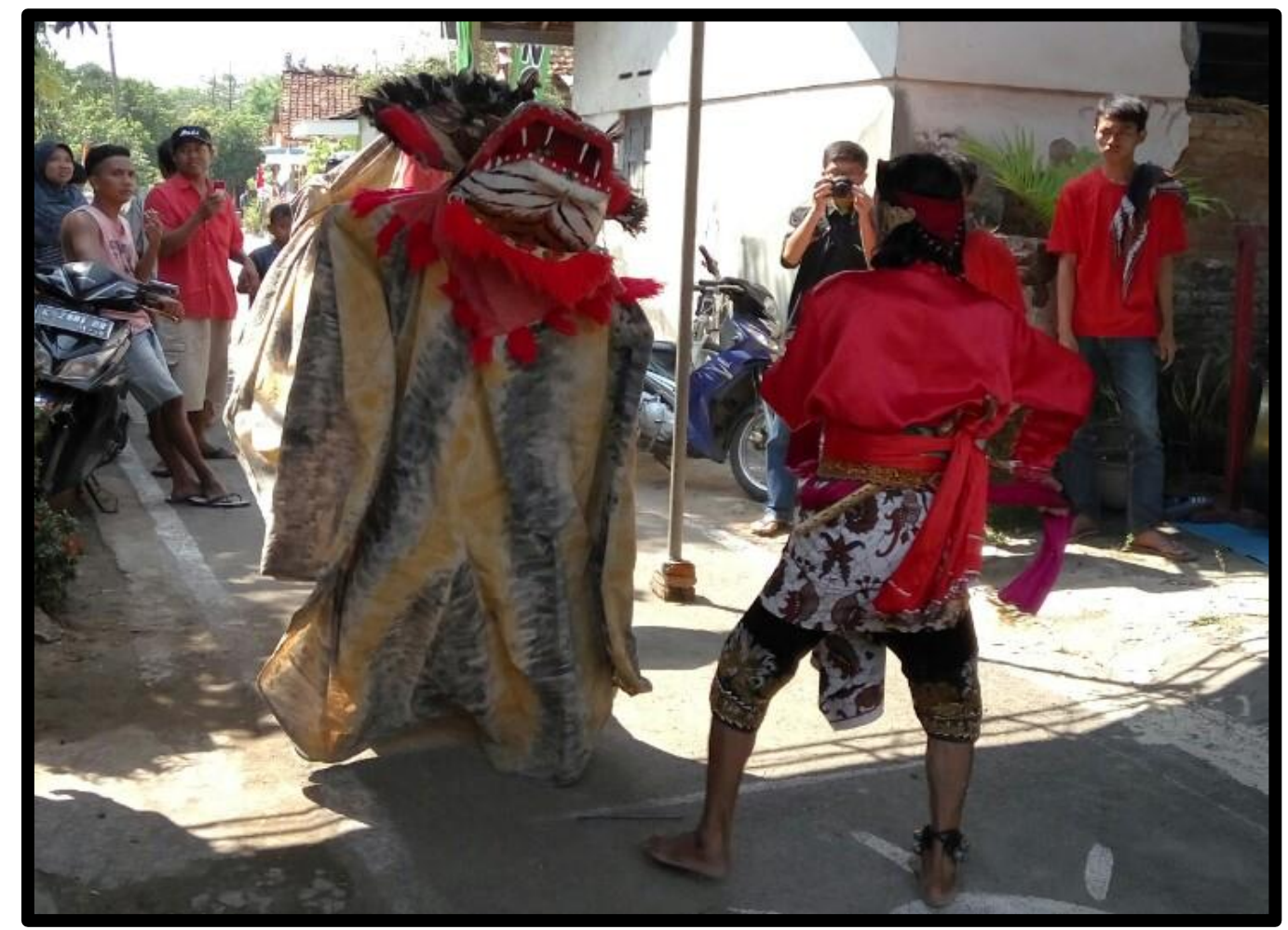

Foto 4.6 Tepisan

(Dokumentasi: Abrilia, April 2016) 


\subsubsection{Klepatan}

Klepatan diibaratkan sebagai upaya menusia untuk menghindar dari segala bahaya yang mengenai dirinya. Gerakan klepatan dilakukan Penthul ketika dia sadar dan harus waspada terhadap kemungkinan serangan yang ada disekitarnya. Pada saat Barongan mulai menari-nari, Penthul melakukan gerakan meloncat ke arah belakang untuk menjauhi Barongan.

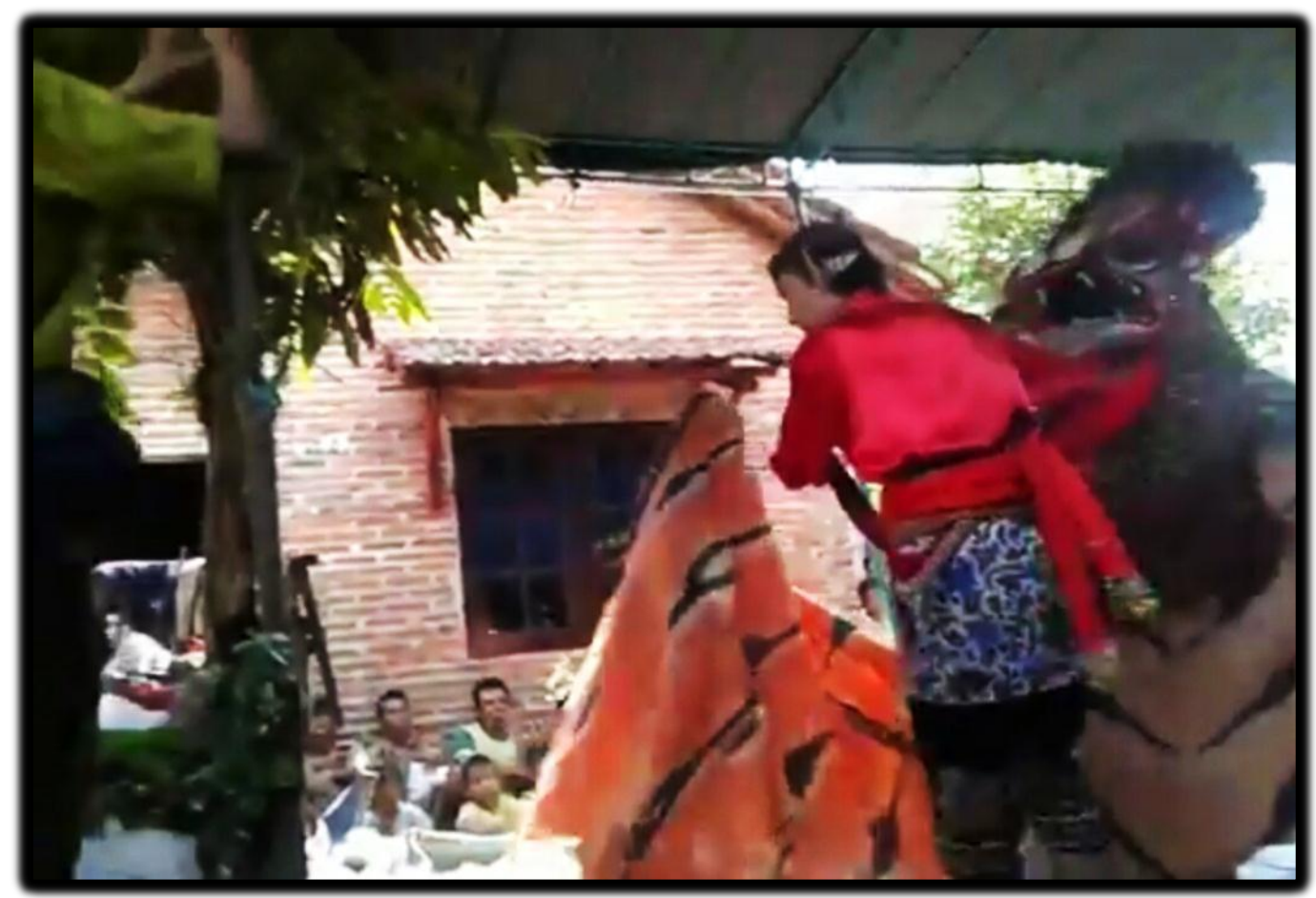

Foto 4.7 Klepatan

(Dokumentasi: Abrilia, April 2016)

\subsubsection{Pancalan}

Pancalan atau sering disebut mancal, dikatakan oleh Bapak Karmin sebagai gerakan utama pada peperangan yang terjadi antara Penthul dengan Barongan. Gerakan mancal merupakan simbol dari gerakan kekuatan kaki untuk perlawanan 
dan perlindungan diri serta untuk mengalahkan musuh. Gerakan mancal dalam pertunjukan Barongan dapat diartikan sebagai tendangan Penthul kepada Barongan yang sedang berperang. Tendangan dilakukan pada bagian akhir peperangan dengan pertanda Barongan telah dikalahkan oleh Penthul. Pada foto 4.8 dapat dilihat Penthul sedang mengangkat kaki kanan akan menendang Barongan. Gerakan inilah yang dinamakan pancalan.

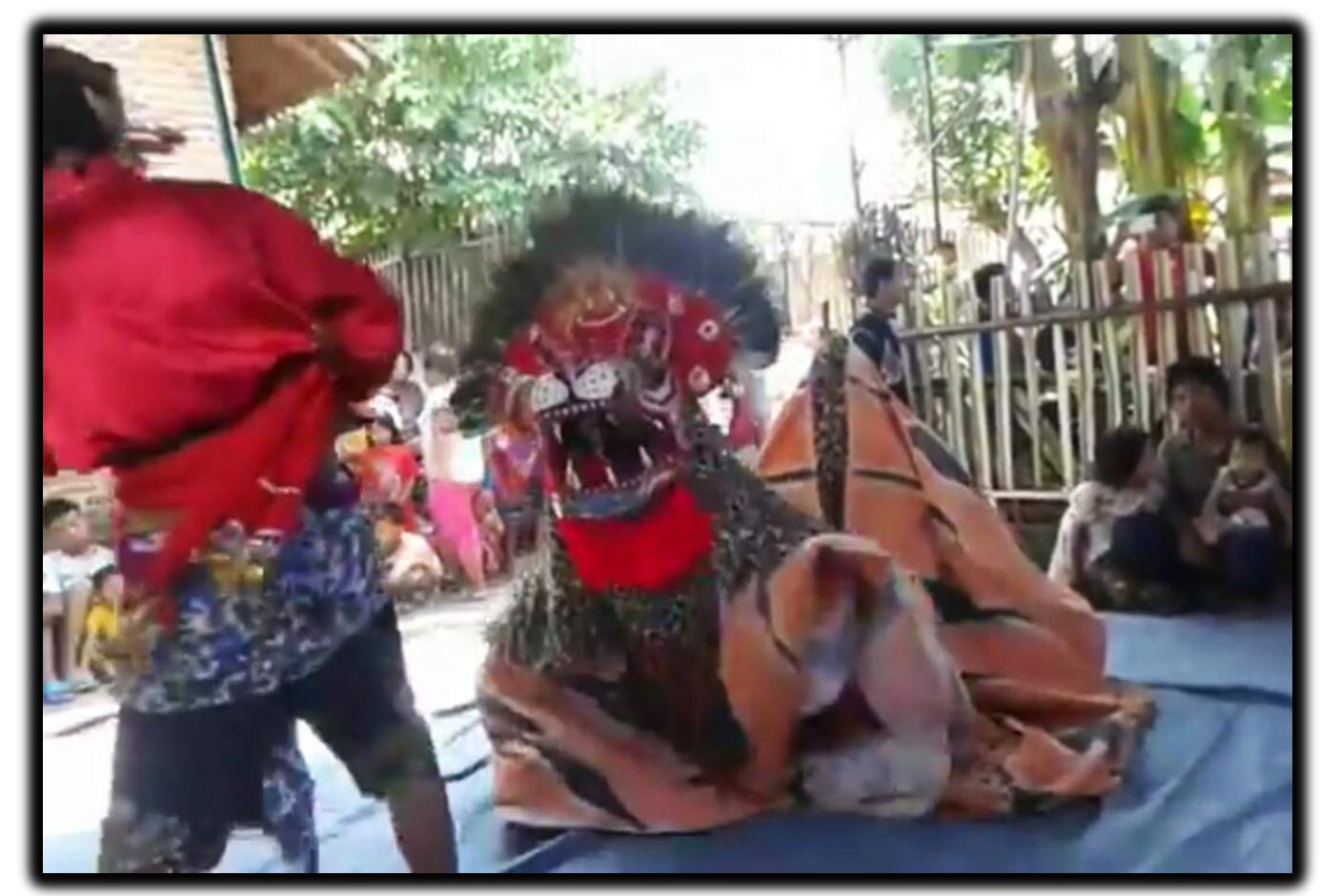

Foto 4.8 Pancalan

(Dokumentasi: Abrilia, April 2016)

\subsubsection{Gerakan Barongan}

\subsubsection{Ngaklak}

Gerakan ngaklak menjadi ciri khas dari suara Barongan, yaitu gerakan membuka tutup mulut Barongan dengan lebar, cepat dan berulang sehingga 
menghasilkan bunyi "klak-klak" dan dilakukan pada posisi kepala Barong menghadap atas hingga bawah. Gerakan ngaklak dilakukan oleh pembarong yang bermakna kekuatan yang dimiliki.

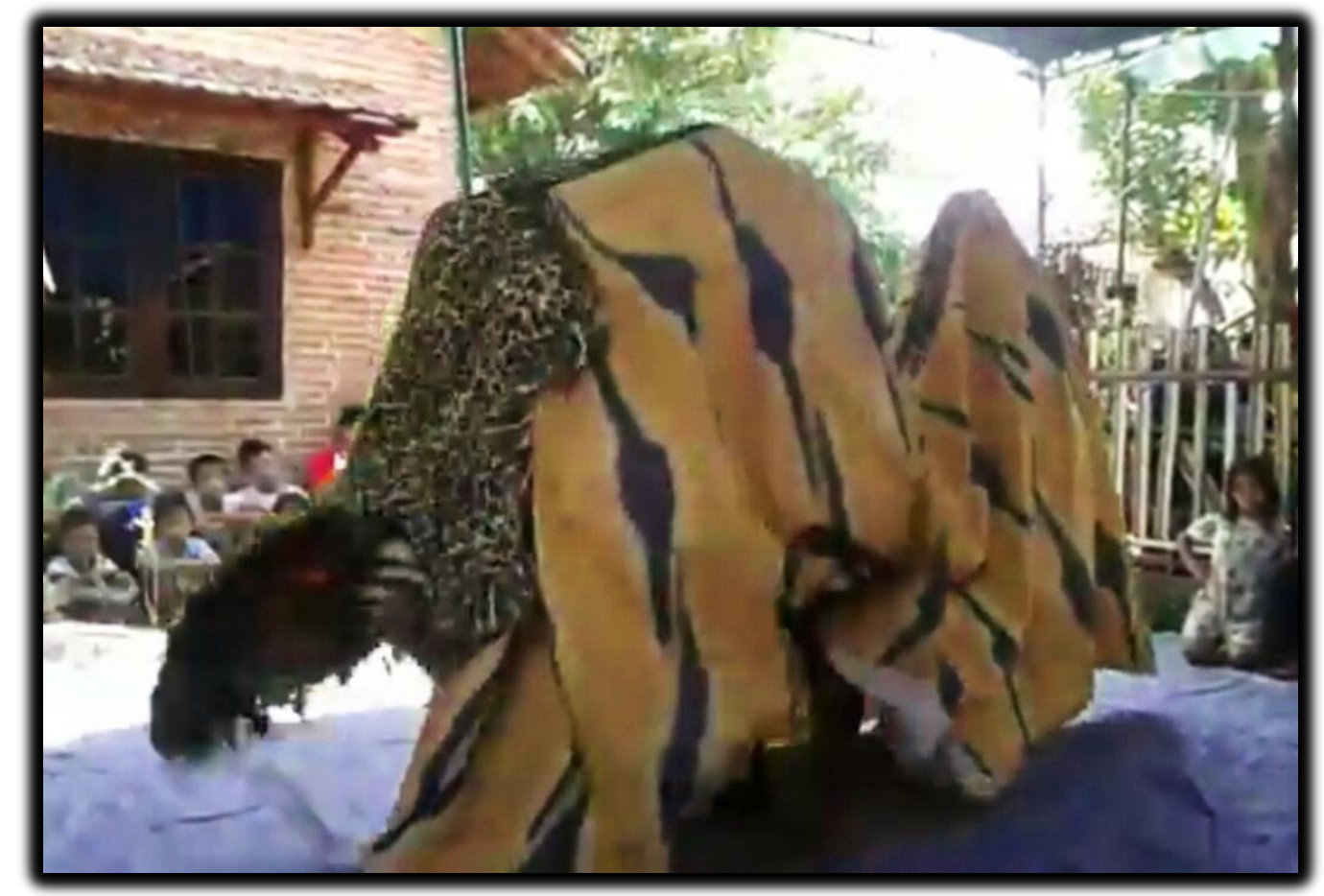

Foto 4.9 Ngaklak

(Dokumentasi: Abrilia, April 2016)

\subsubsection{Caplokan}

Caplokan memiliki pengertian yang hampir sama dengan ngaklak. Yaitu membuka lebar kemudian menutup mulut Barongan, namun pada caplokan tidak terjadi pengulangan gerak. Gerakan caplokan memiliki beberapa makna. Pada tahap peperangan dengan Penthul, caplokan disimbolkan sebagai gerakan perlawanan yaitu ingin menyerang Penthul. Sedangkan pada acara ruwatan, caplokan dimaknai dengan simbol dicaploknya (dimakannya) anak sukerta yang sedang diruwat. 
Berbeda lagi pada acara arak-arakan, gerakan caplokan biasanya difungsikan sebagai media mengambil uang pemberian beberapa warga yang nantinya rumah mereka akan didatangi Barongan.

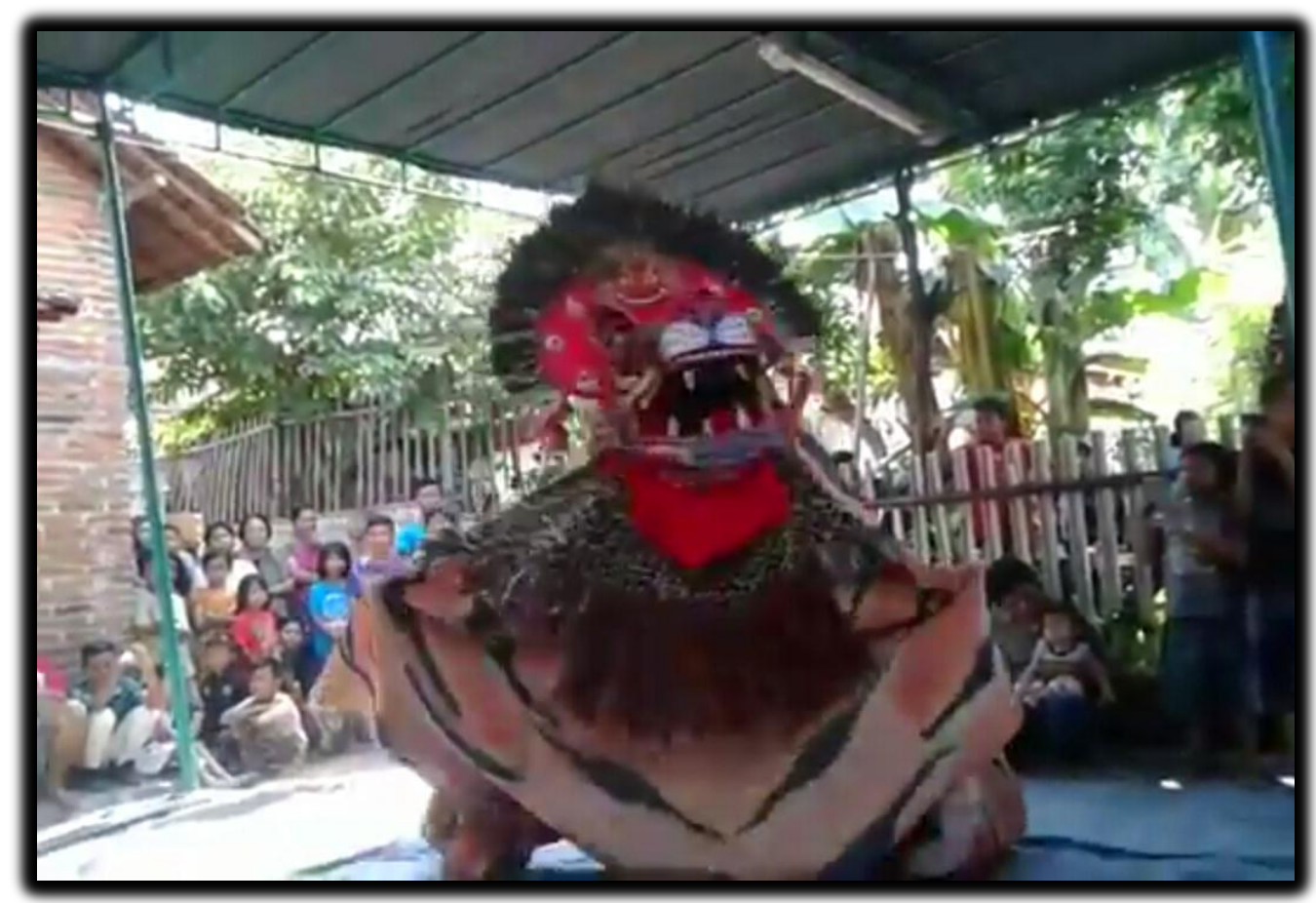

Foto 4.10 Caplokan

(Dokumentasi: Abrilia, April 2016)

\subsubsection{Ndekem}

Ndekem atau biasa disebut dengan dekeman adalah gerakan Barongan pada level rendah dalam sebuah tarian. Dekeman merupakan posisi di mana kepala dan badan barong menempel pada lantai. Gerakan dekeman dapat dilihat pada akhir pertunjukan inti kesenian Barongan karena dekeman menjadi pertanda sang Barong telah menyerah kalah oleh serangan Penthul. 


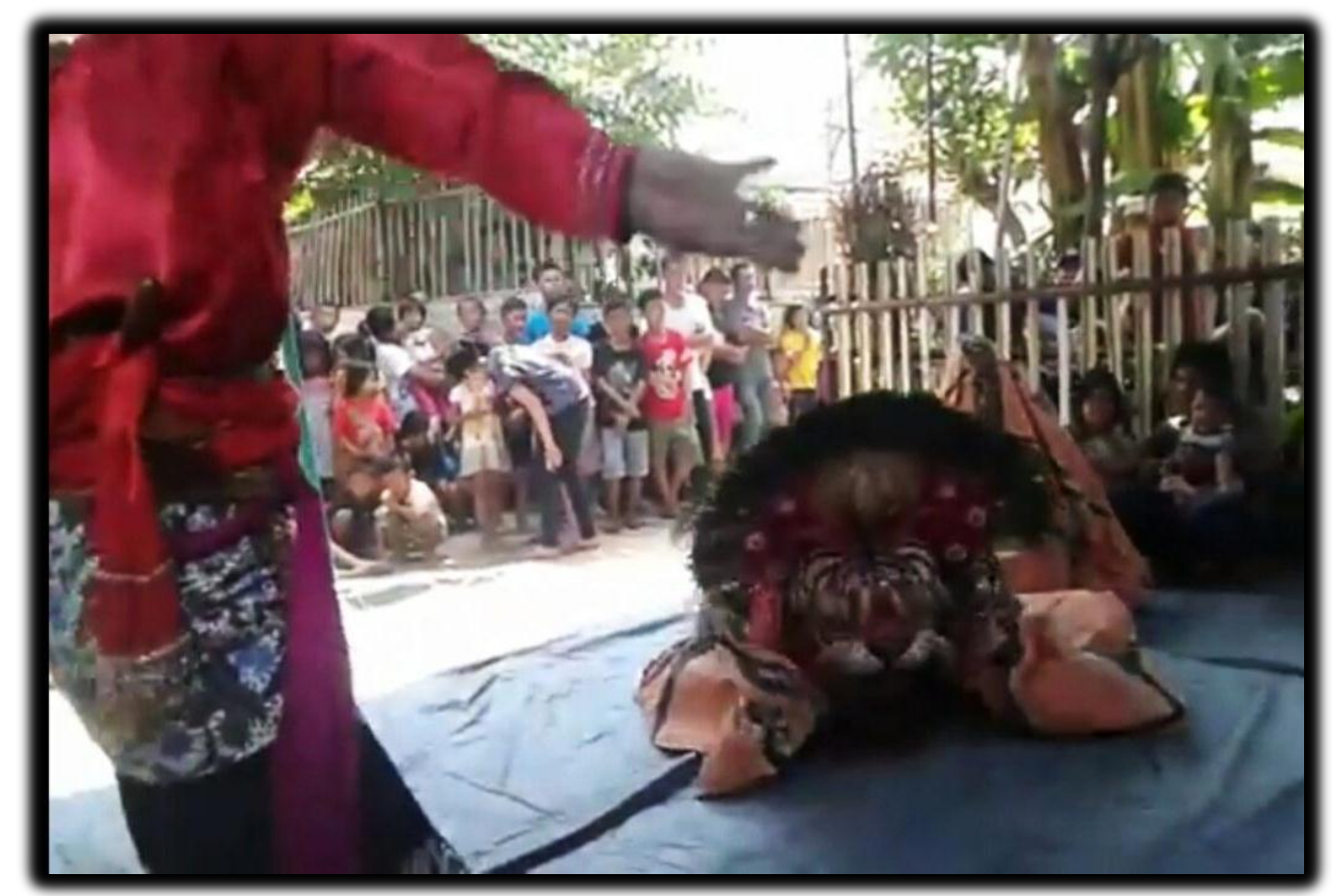

Foto 4.11 Ndekem

(Dokumentasi: Abrilia, April 2016)

\subsubsection{Glundungan}

Glundungan adalah gerakan menjatuhkan badan ke arah belakang, kanan atau ke kiri yang dilakukan Barongan pada saat mendapat tendangan dari Penthul. Glundungan membutuhkan kekompakan dari pemain yang berperan menjadi kepala barong dan ekor barong karena apabila kepala barong menjatuhkan badan ke arah kanan atau sebaliknya, maka ekor barong juga harus mengikuti dengan gerakan yang sama. Foto 4.12 menunjukan Barongan dalam proses gerakan glundungan dengan menjatuhkan badan kearah kanan karena kalah melawan Penthul. 


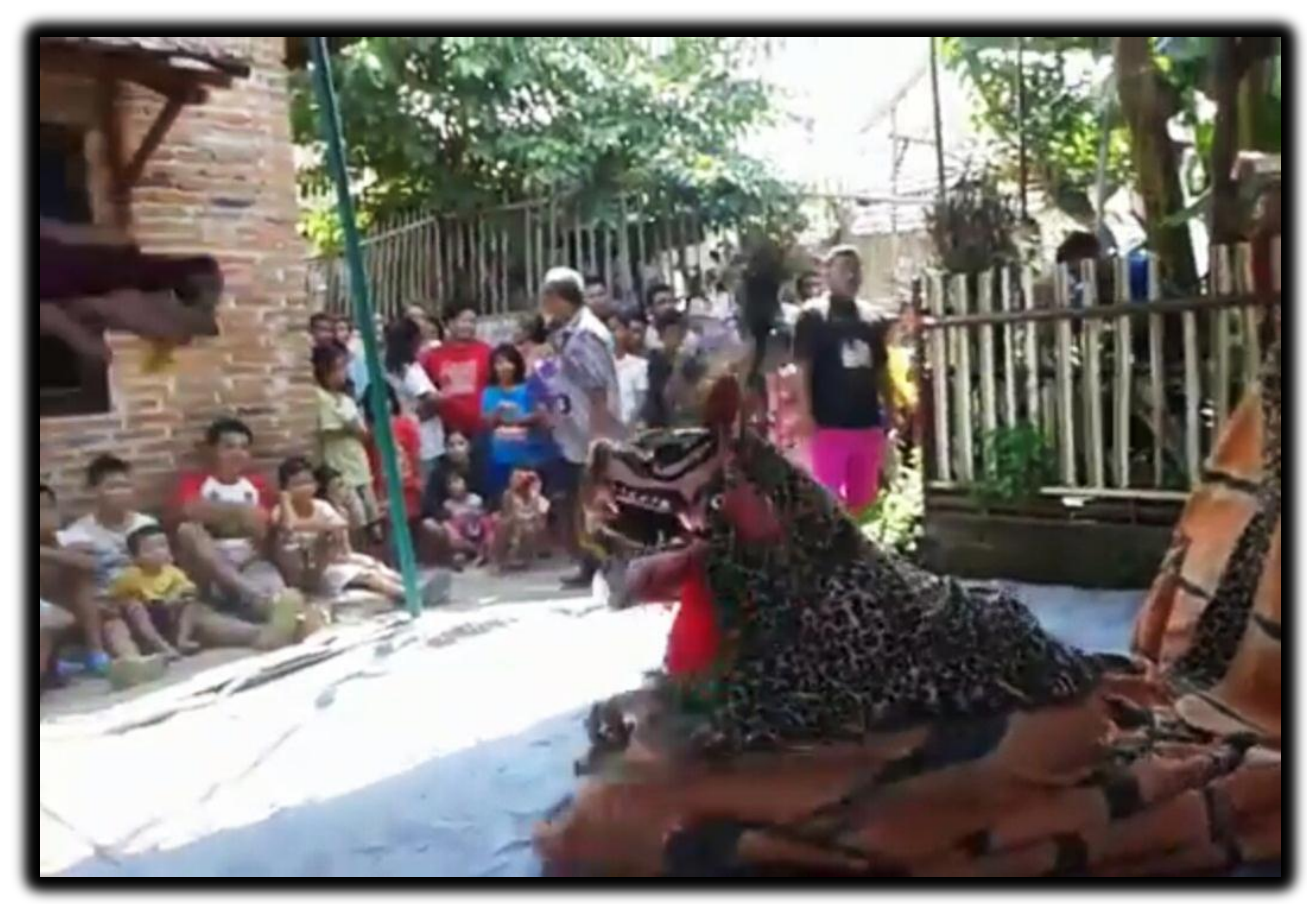

Foto 4.12 Glundungan

(Dokumentasi: Abrilia, April 2016)

\subsubsection{Pelaku (Penari)}

Di dalam pertunjukan seni terutama kesenian Barongan, penari menjadi faktor utama sebagai pelaku. Pelaku tari yang terdapat pada kesenian Barongan Wahyu Budaya antara lain 2 orang pelaku Macan Barong berperan menjadi kepala dan ekor, 2 orang pelaku Singa Barong berperan menjadi kepala dan ekor, 1 orang Penthul, 1 orang Bondet atau lebih sering disebut celeng (babi hutan) dan 5 orang penari kuda lumping. 


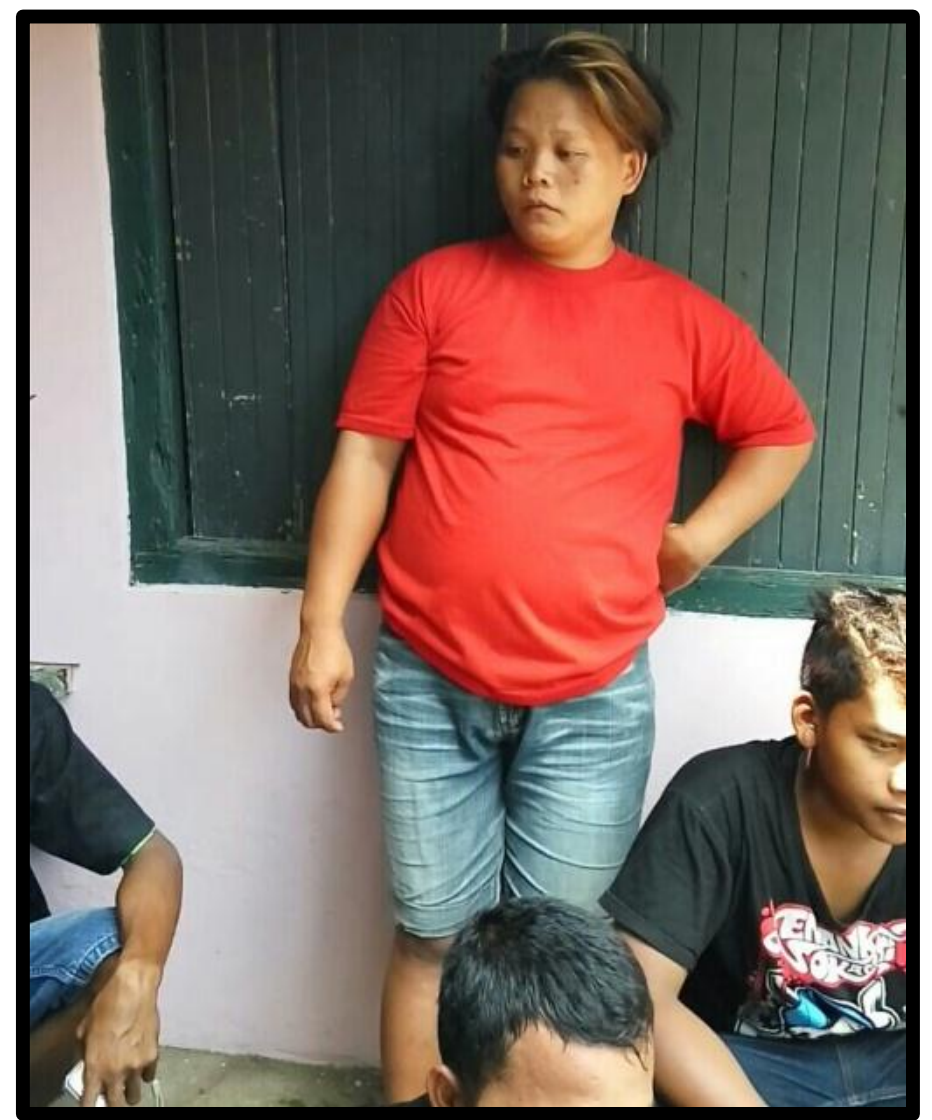

Foto 4.13 Eko Wahyudi (Pembarong utama)

(Dokumentasi: Abrilia, April 2016)

\subsubsection{Iringan}

Iringan dalam tari berfungsi untuk mengiringi tari dan memberikan suasana dalam kesenian Barongan khususnya pada kelompok kesenian Wahyu Budaya. Iringan memiliki peran yang sangat penting dalam pertunjukan kesenian Barongan, hal tersebut disebabkan kerena gerkan Barongan lebih bersifat spontanitas dan banyak melakukan improvisasi mengikuti iringan musik yang dimainkan.

Musik tari Barongan tampak lebih hidup, karena iringan musik Barongan mudah sekali dikenali oleh masyarakat. Masyarakat dapat dengan mudah mengenali musik Barongan karena notasi dari iringan Barongan berpola ritmis dan aksen 
iringan Barongan diulang-ulang secara teratur. Maka dari itu iringan kesenian Barongan tergolong menjadi iringan yang sederhana sesuai dengan ciri-ciri kesenian kerakyatan.

Iringan musik dalam pertunjukan Barongan Wahyu Budaya menggunakan gamelan yang tidak berlaras. Mengapa dikatakan demikian karena melihat komposisi instrumen yang digunakan, musik iringan kesenian Barongan tidak dapat dikatakan memiliki jenis laras slendro maupun laras pelog. Bentuk iringan pertunjukan kesenian Barongan Wahyu Budaya berupa gending lancaran Barongan dengan notasi berpola ritmis dan aksen yang diulang-ulang, sehingga iringan terasa dominan karena bonang barung laras slendro bernada 5 dan 6 dipukul secara bergantian. Sedangkan pengendali irama cepat dan lambat terletak pada kendang. Alat pengiring kesenian Barongan Wahyu Budaya antara lain:

1. Kendang merupakan instrumen dalam gamelan Jawa yang salah satu fungsi utamanya adalah untuk mengatur irama, dibunyikan dengan tangan tanpa alat bantu lainnya. Terbuat dari kayu bulat dengan rongga dibagian tengahnya dan ditutup menggunakan kulit binatang pada kedua ujung.

2. Kempul laras slendro (bernada lima) merupakan jenis instrumen musik pukul yang terbuat dari lempeng besi atau kuningan melalui tahap pembentukan yang dibentuk bulat menonjol (pencu) pada bagian tengah dan memiliki fungsi sebagai variasi gendhing. 
3. Kenong

Kenong merupakan alat musik yang menyusun gamelan Jawa. Dimainkan dengan cara dipukul menggunakan pemukul dari kayu keras yang dililit kain atau benang gulung.

4. Bonang barung laras slendro (bernada lima dan enam) merupakan instrumen musik tetabuhan keras yang terbuat dari logam. Teknik memukulnya adalah dengan cara dipukul pada bagian tengah yang menonjol menggunakan alat pemukul khusus.

5. Slompret

Slompret merupakan alat musik tiup tradisional berbentuk seperti seruling namun menghasilkan jenis suara yang berbeda. Pada pertunjukan kesenian Barongan memakai Slompret Reog yang berasal dari Ponorogo Jawa Timur.

\section{Gong}

Alat musik gong merupakan alat musik pukul yang terbuat dari leburan logam perunggu dengan tembaga dengan permukaan bundar dan memiliki pencu di bagian tengah. Alat musik gong dapat digantung pada bingkai atau diletakkan berjajar pada rak. Apabila dipukul menghasilkan bunyi "gong" sehingga alat musik ini diberi nama gong.

Iringan kesenian Barongan dominan pada instrumen musik slompret dan bonang barung bernada 5 dan 6 yang dipukul secara bergantian. 
Pada awal pertunjukan Barongan Wahyu Budaya memilih lagu berjudul Godril.

Syair (cakepan) Godril :

Mangkene gendhing godril

Mangkene godril budi dayanen amrih kasil

Aja jail methakil aja ngruwil

Yen wis lembah manah lan sumarah

Nastiti ngati-ati dalan selamet ing dhiri

Kakang mbakyu thole gendhuk rama ibu

Lamun tandhang tanduk tingkah laku mawas diri adoh pasulayan

Syair Godril pada pertunjukan Barongan Wahyu Budaya tidak ada ketentuan harus sama persis dengan lirik aslinya. Syair Godril yang digunakan dalam pertunjukan kesenian Barongan Wahyu Budaya adalah Godril Tayub. Pembuka pertunjukan dimulai dengan memainkan alat musik kemudian Penthul menari diikuti masukknya Barongan ke arena pertunjukan dan menari bersama diiringi gendhinggendhing sebagai berikut: 
Iringan Pembuka

\section{Godril}

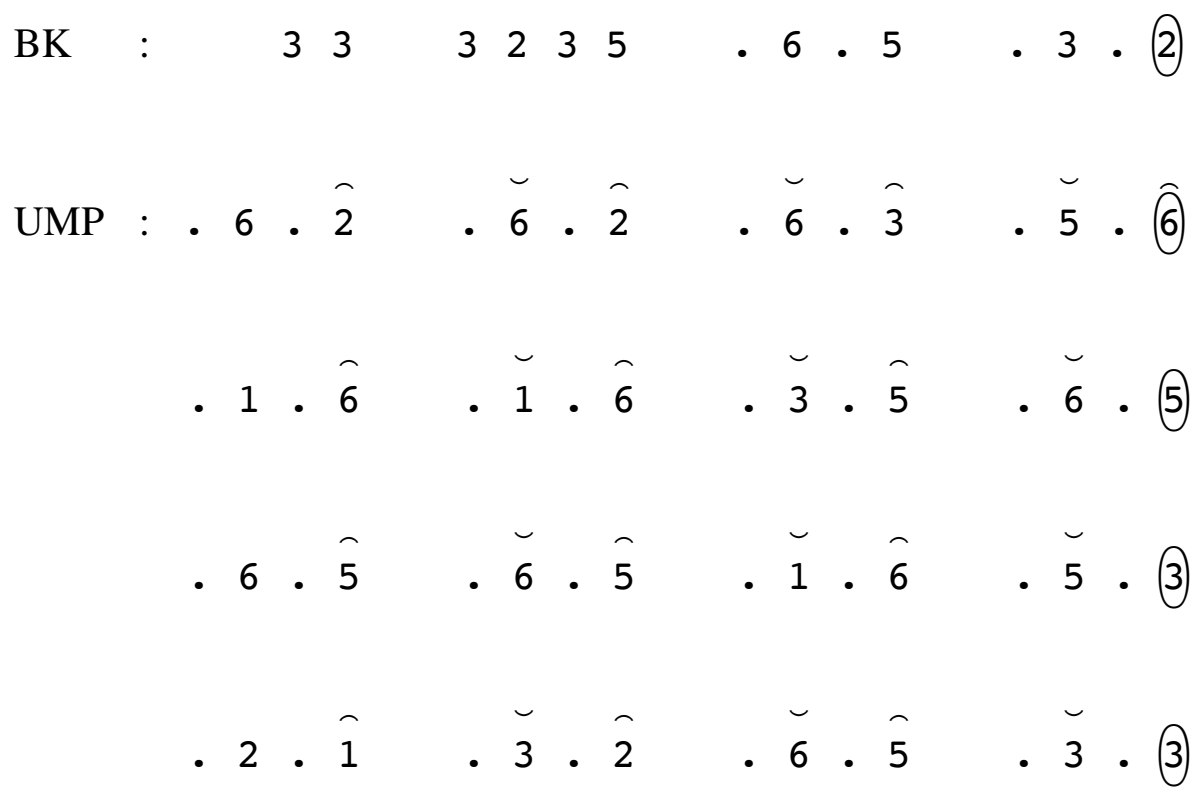

Keterangan :

\begin{tabular}{ll} 
BK & : Pembuka \\
UMP & $:$ Umpak \\
& $:$ Kenong \\
& $:$ Kempul \\
& \\
\hline & $:$ Gong
\end{tabular}


Iringan Barongan

BK : Pbl P.

Slompret : $\left[\begin{array}{llll}6 & 5 & 6 & 5\end{array}\right]$

$\overline{15} \overline{65} \overline{15} \overline{65} \quad \overline{32} \overline{32} \overline{35} \overline{65} \quad \overline{15} \overline{65} \overline{15} \overline{65} \quad \overline{32} \overline{32} \overline{35} \overline{65}$

\section{Sampak SL. Manyuro}

$\begin{array}{llllllllllll}6 & 6 & 6 & 6 & 3 & 3 & 3 & 3 & 2 & 2 & 2 & 2\end{array}$

$\begin{array}{llllllllllll}2 & 2 & 2 & 2 & 3 & 3 & 3 & 3 & 1 & 1 & 1 & (1)\end{array}$

$\begin{array}{llllllllllll}1 & 1 & 1 & 1 & 2 & 2 & 2 & 2 & 6 & 6 & 6 & 6\end{array}$

Srampat

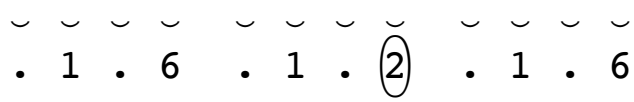

keterangan :

BK : pembuka

P : : Pung

be : Dlang

: Kenong

$\checkmark \quad$ Kempul

O : Gong 


\section{Iringan Kuda Lumping}

Ketawang Puspowarno sc Manyuro

Instrumen

$$
\begin{array}{rrrrr}
\text { BK } & : 6.123 & .2 .1 & .3 .2 & .1 .6 \\
\text { UMP } & : .2 .3 & .2 . \hat{1} & .3 .2 & .1 .6 \\
\text { Lagu } & . .6 . & 232 \hat{1} & 326 \tilde{5} & 165(3) \\
& . .32 & 532 \hat{1} & .3 .2 & .1 .6 \\
.2 .3 & .2 . \hat{1} & .3 .2 & .1 .6
\end{array}
$$

Ketawang Puspowarno sc Manyuro

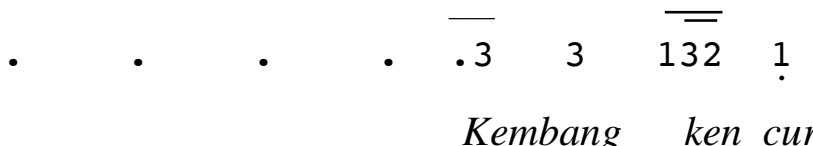

$$
\begin{aligned}
& \begin{array}{lllllll}
\overline{6123} & \overline{\overline{26}} & 5 & .6 & 6 & \overline{6165} & 3
\end{array} \\
& \text { Kacaryam ang gung ci na tur } \\
& \text { - . } \quad \overline{61} \overline{2 \overline{12}} \overline{31 \overline{26}} \quad 3 \overline{35 \overline{32}} 1 \\
& \text { Sedhet kang sa ri ra } \\
& \begin{array}{lllll}
\overline{335} & 2 & \overline{.35} & 3 & \overline{121}
\end{array} \\
& \text { Gan des ing wira ga }
\end{aligned}
$$




\begin{tabular}{|c|c|c|c|c|c|c|}
\hline \multirow[t]{2}{*}{ • } & $\overline{35}$ & 2 & $\overline{3}$ & 5 & $\overline{23 \overline{21}}$ & 6 \\
\hline & $K e$ & Wes & yen & ngan & $d i$ & $k a$ \\
\hline • & $\overline{35}$ & 2 & $\overline{. \overline{35}}$ & $\begin{array}{ll}5 & 3\end{array}$ & $\overline{1 \overline{21}}$ & 6 \\
\hline & $A n_{z}$ & & $a n$ & $y u t$ & $\quad j i$ & $w a$ \\
\hline
\end{tabular}

\subsubsection{Tata Rias dan Busana}

Tata rias dan busana yang digunakan dalam pertunjukan kesenian Barongan lebih menonjol pada pelaku Penthul karena pada kesenian Barongan Wahyu Budaya, pemeran Penthul tidak lagi memakai topeng melainkan dengan meris wajah sendiri menggunakan rias gagah prengesan. Rias gagah prengesan merupakan karakter ksatria yang gagah pemberani. Penggambaran karakter gagah pemberani terlihat pada bagian alis yang dipertebal, bagian mata yang dipertajam, serta kumis yang dipertebal dengan dasar wajah berwarna merah menjadi penggambaran sifat gagah perkasa seorang ksatria. Penggunaan rias pada lakon Penthul sedikit lebih tebal karena tidak semua penonton dapat melihat pertunjukan dari jarak dekat.

Tata busana yang digunakan dalam pertunjukan kesenian Barongan Wahyu Budaya juga hanya terlihat menonjol pada lakon Penthul. Tidak ada ketentuan baku yang mengatur tentang tata cara berbusana untuk pertunjukan Barongan Wahyu Budaya. Sedangkan untuk pemain yang lain menggunakan properti topeng dan untuk penari kuda lumping memilih menggunakan seragam perkumpulan remaja Desa Loram Kulon. 


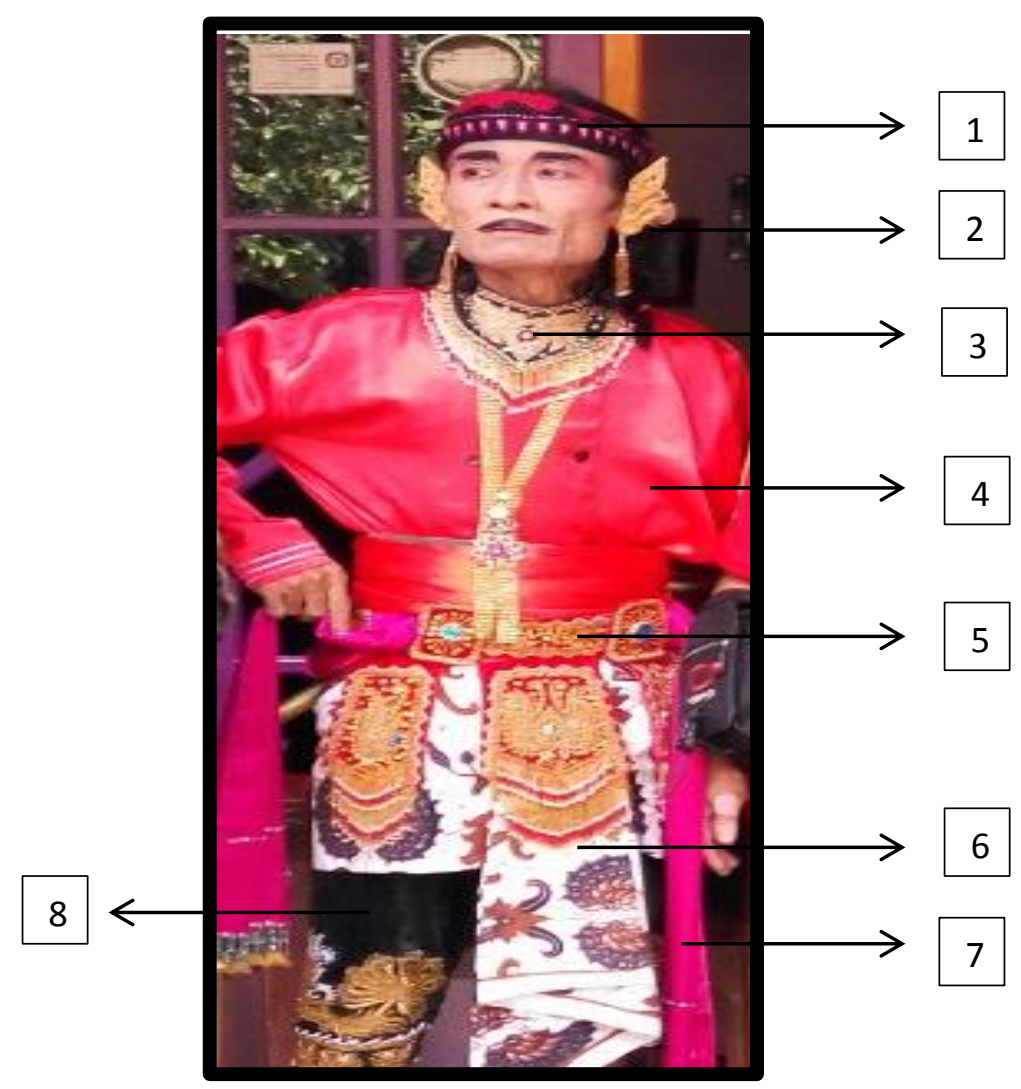

Foto 4.14 Tata Rias dan Busana Penthul

(Dokumentasi: Abrilia, April 2016)

Busana yang dikenakan oleh Penthul dalam pertunjukan Barongan antara lain

1. Iket atau udheng adalah kain yang diwiru atau di lipat dan diikatkan pada kepala

2. Sumping adalah sejenis perhiasan yang dikenakan pada telinga.

3. Kace adalah kalung dari kain bludru berhiaskan manik-manik warna kuning emas.

4. Baju Kurung polos berwarna merah mengkilap dari bahan satin.

5. Sabuk Bara-bara adalah sabuk yang terbuat dari bahan kain bludru dihiasi monte warna kuning emas.

6. Jarik supit urang

7. Sampur 
8. Celana panji atau kepanjen warna hitam terbuat dari bahan bludru dengan bordiran monte emas tepat selutut sampai paha, panjanh celana menutupi lutut penari.

Busana atau pakaian yang digunakan oleh Barongan adalah topeng kepala macan yang terbuat dari kayu, diukur menyerupai wajah raja hutan, dilengkapi dengan hiasan diatas kepala berupa bulu merak untuk Barongan utama dan bulu angsa untuk Barongan ke dua. Sebagai badan atau tubuh, terbuat dari kain lebar, kuat dan tebal bermotif loreng hitam kuning yang ujungnya dikaitkan pada kepala Barongan.

\subsubsection{Properti}

Properti merupakan segala perlengkapan atau peralatan yang terkait dengan penari seperti senjata. Properti yang digunakan dalam pertunjukan kesenian Barongan Wahyu Budaya adalah topeng Barongan, topeng Bondet, kuda kepang, pecut, gelang kaki (kerincingan) dan keris.

1. Topeng Barongan

Topeng Barongan yang digunakan pada pertunjukan kesenian Barongan Wahyu Budaya ada 2 macam. 


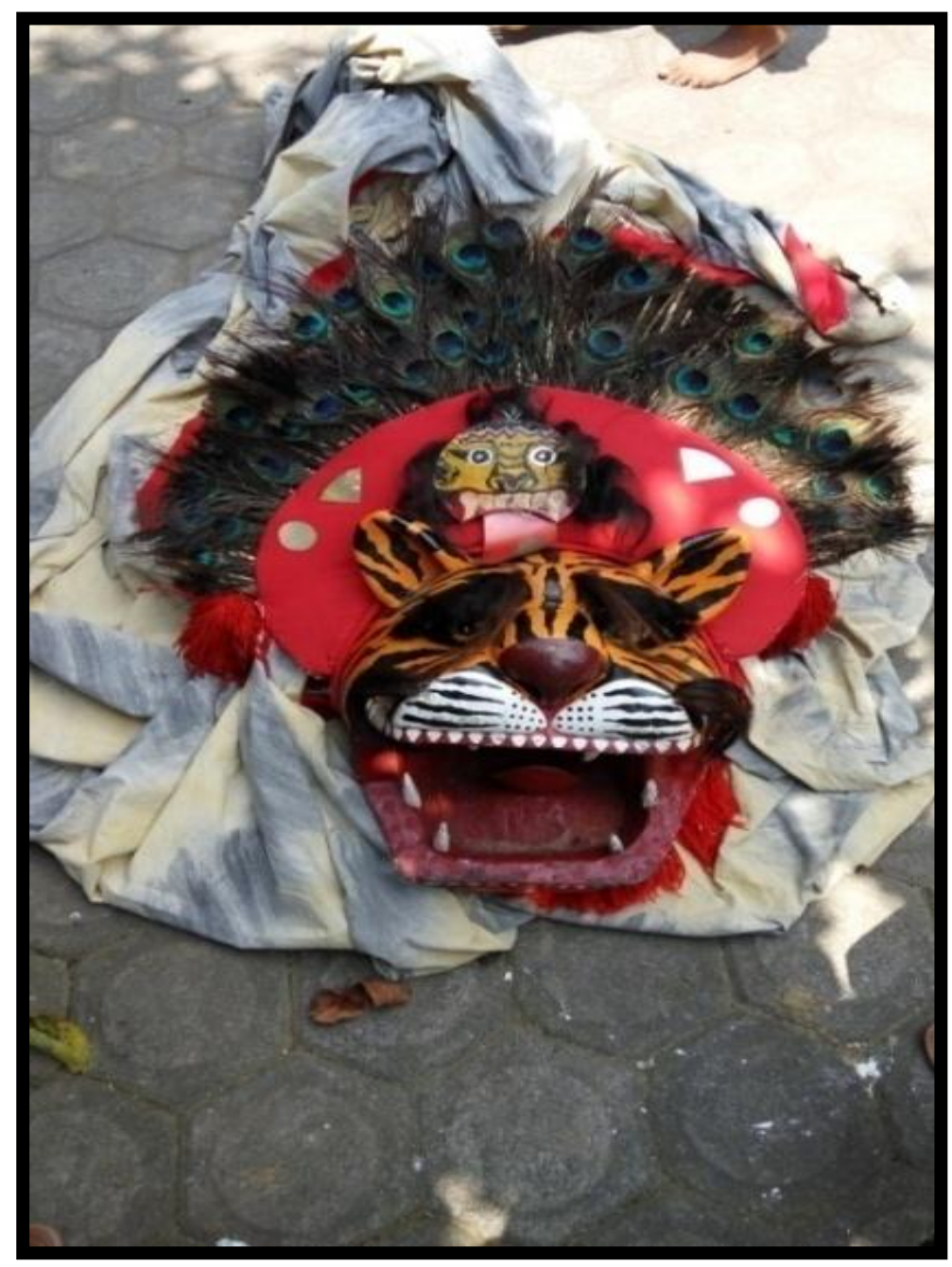

Foto 4.15 Bentuk Barongan 1 Wahyu Budaya

(Dokumentasi: Abrilia, April 2016)

Foto 4.15 merupakan topeng Macan Barong yang menjadi peran utama dalam pertunjukan kesenian Barongan Wahyu Budaya. Kepala Macan Barong terbuat dari kayu pohon Mahoni, di bagian atas terdapat hiasan dari bulu merak. Untuk bagian badan Barongan dipasang kain lebar dan panjang bermotif loreng hitam dan kuning. 


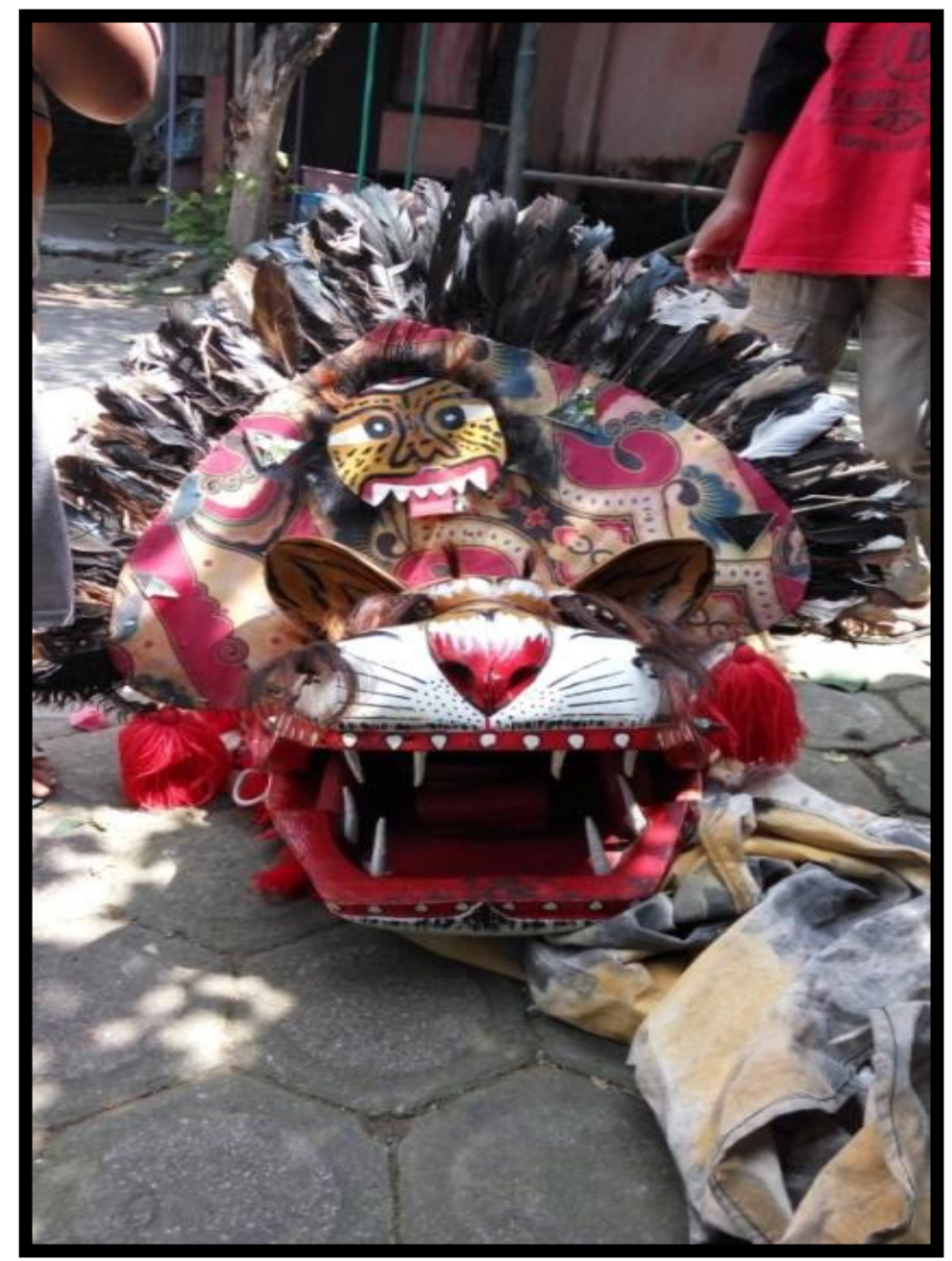

Foto 4.16 Bentuk Barongan 2 Wahyu Budaya (Dokumentasi: Abrilia, April 2016)

Foto 4.16 menunjukkan bentuk Barongan 2 yaitu Singa Barong yang menjadi pendamping Barong utama. Kepala Singa Barong bahan utamanya sama terbuat dari kayu pohon mahoni namun di bagian atas kepala menggunakan bulu angsa dan bulu kalkun. Untuk bagian badan dipasangkan kain loreng berwarna hitam kuning.

\section{Topeng Bondet}

Peran Bondet dalam pertunjukan kesenian Barongan Wahyu Budaya menggunakan properti topeng berwarna merah dengan hidung besar dan panjang 
dilengkapi penutup kepala berupa kain berwarna orange. Topeng Bondet dapat dilihat pada foto 4.17

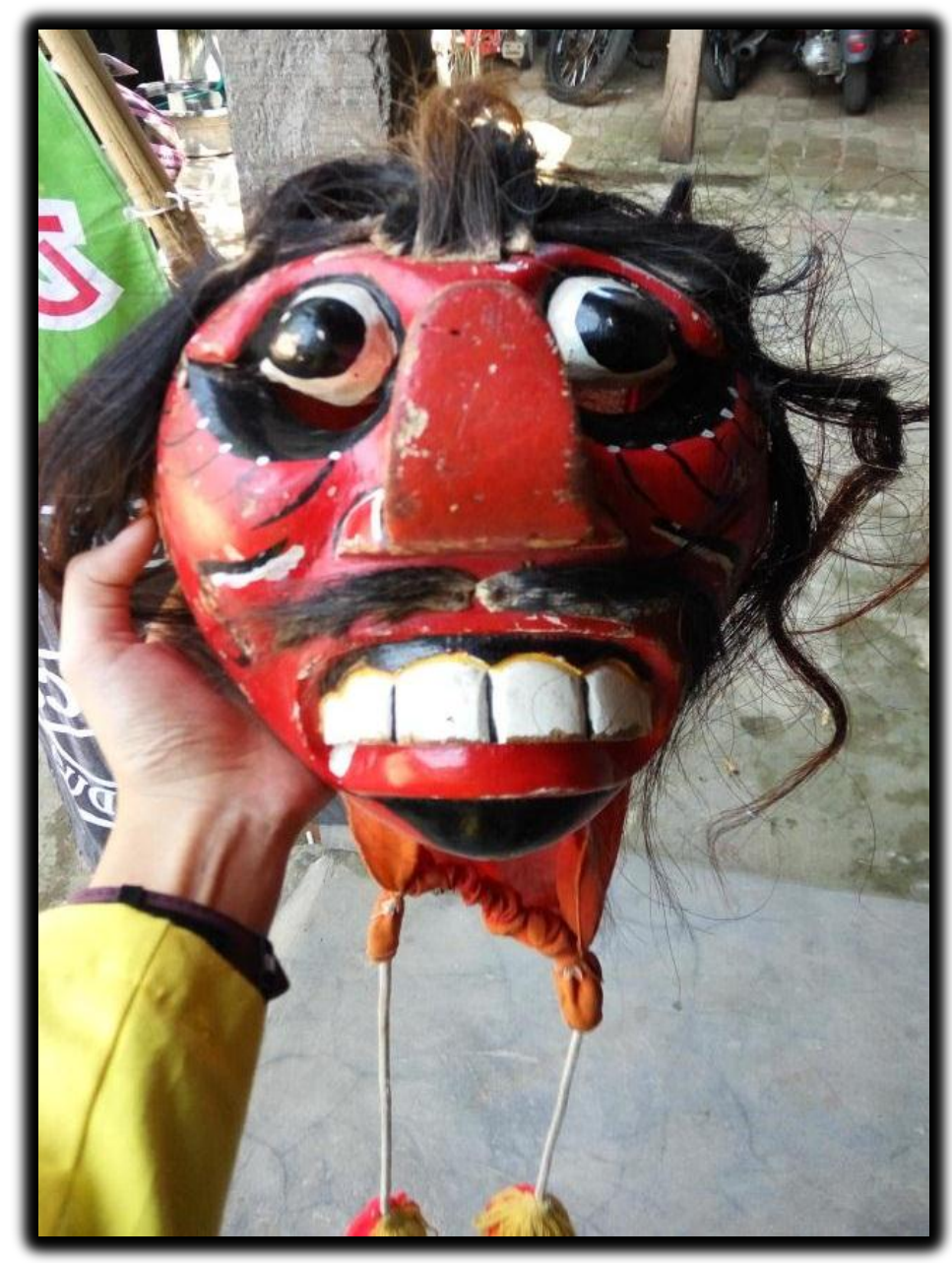

Foto 4.17 Topeng Bondet

(Dokumentasi: Abrilia, April 2016)

\section{Kuda Kepang}

Kuda Kepang atau Kuda Lumping menjadi salah satu properti wajib pada pertunjukan kesenian Barongan. Bapak Sukadi memilih dua jenis warna kuda kepang yaitu hitam dan putih untuk melengkapi kesenian Barongan Wahyu Budaya. Kuda 
yang terbuat dari anyaman bambu ini dipilih dari bahan bambu yang berkualitas dimaksudkan supaya lebih awet dalam pemakaian.

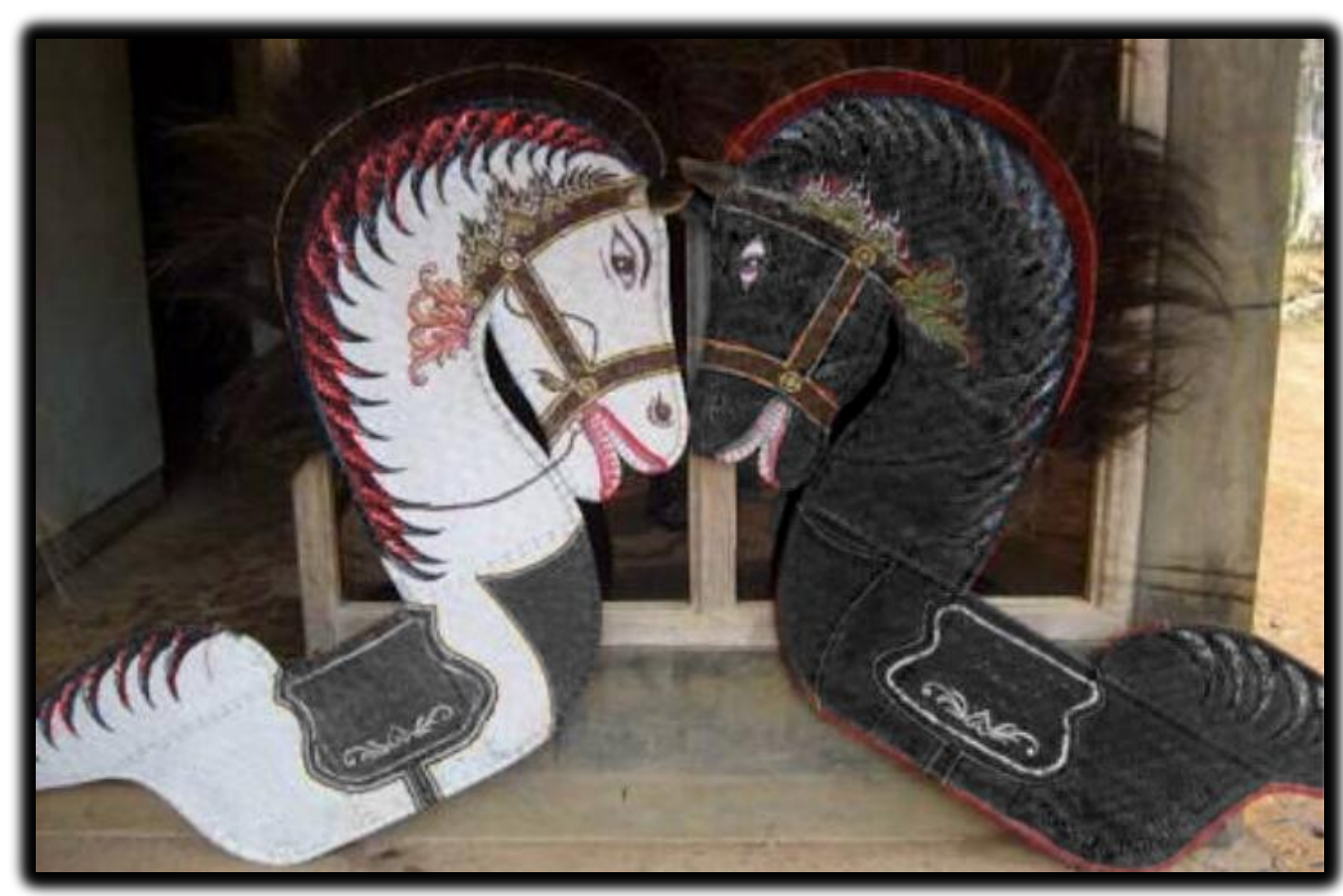

Foto 4.18 Kuda Kepang

(Dokumentasi: Abrilia, April 2016)

\section{Pecut}

Pecut atau cambuk merupakan properti pelengkap dari Kuda Lumping. Pecut digunakan untuk mencambuk para pemain Kuda Lumping yang sudah dibacakan mantra oleh pawang sehingga para pemain Kuda Lumping tidak merasakan sakit walaupun dicambuk berkali-kali. Pada foto 4.19 memperlihatkan pecut yang digunakan dalam pertunjukan kesenian Barongan Wahyu Budaya. 


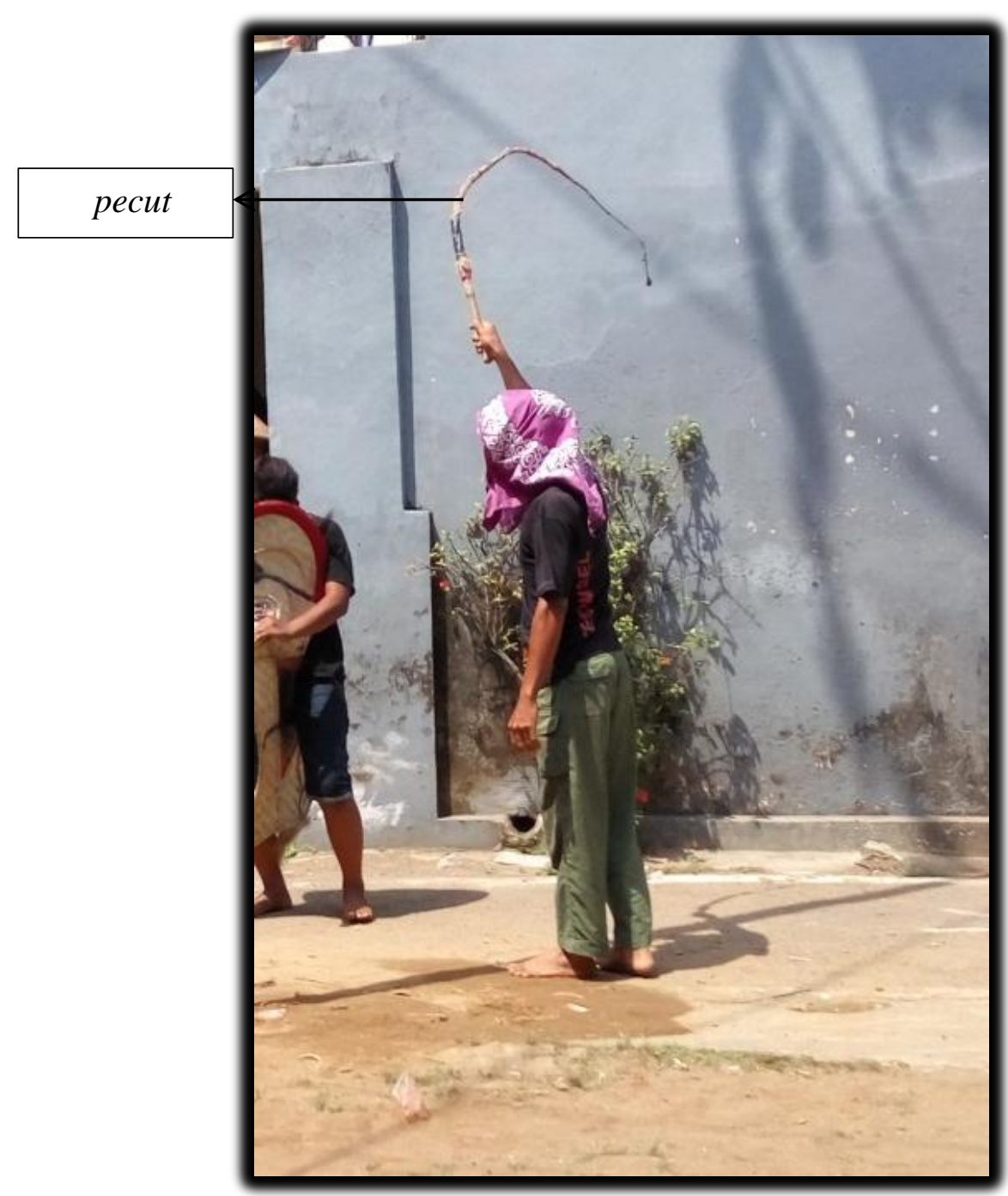

Foto 4.19 Pecut

(Dokumentasi: Abrilia, April 2016)

\section{Kerincingan}

Properti lonceng atau yang disebut kerincingan dipakai Penthul pada pergelangan kaki kanan. Kerincingan dipakai oleh Penthul dengan tujuan agar tercipta bunyi "krincing-krincing" pada setiap hentakan kaki Penthul. 


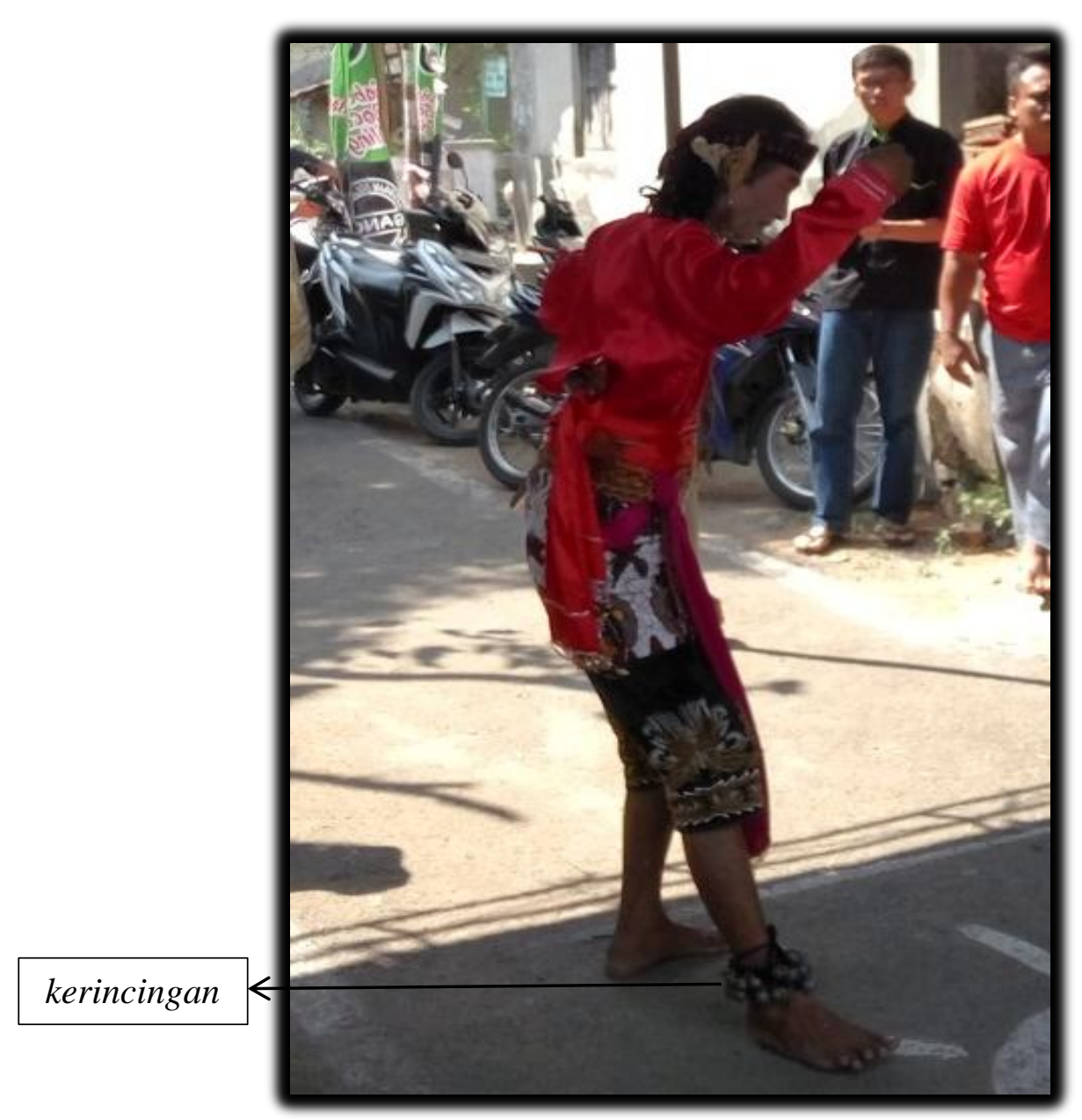

Foto 4.20 Kerincingan

(Dokumentasi: Abrilia, April 2016)

\section{Keris}

Keris dipakai oleh Penthul di pinggang bagian pinggang belakang dengan cara menyelipkan keris pada sabuk atau sampur. Keris yang diletakkan pada bagian pinggang belakang mempunyai arti tidak digunakan untuk berperang. Seperti pada pertunjukan Barongan Wahyu Budaya, sang Penthul memakai keris dibagian pinggang belakang hanya untuk pelengkap supaya terlihat gagah dan bukan untuk berperang. 


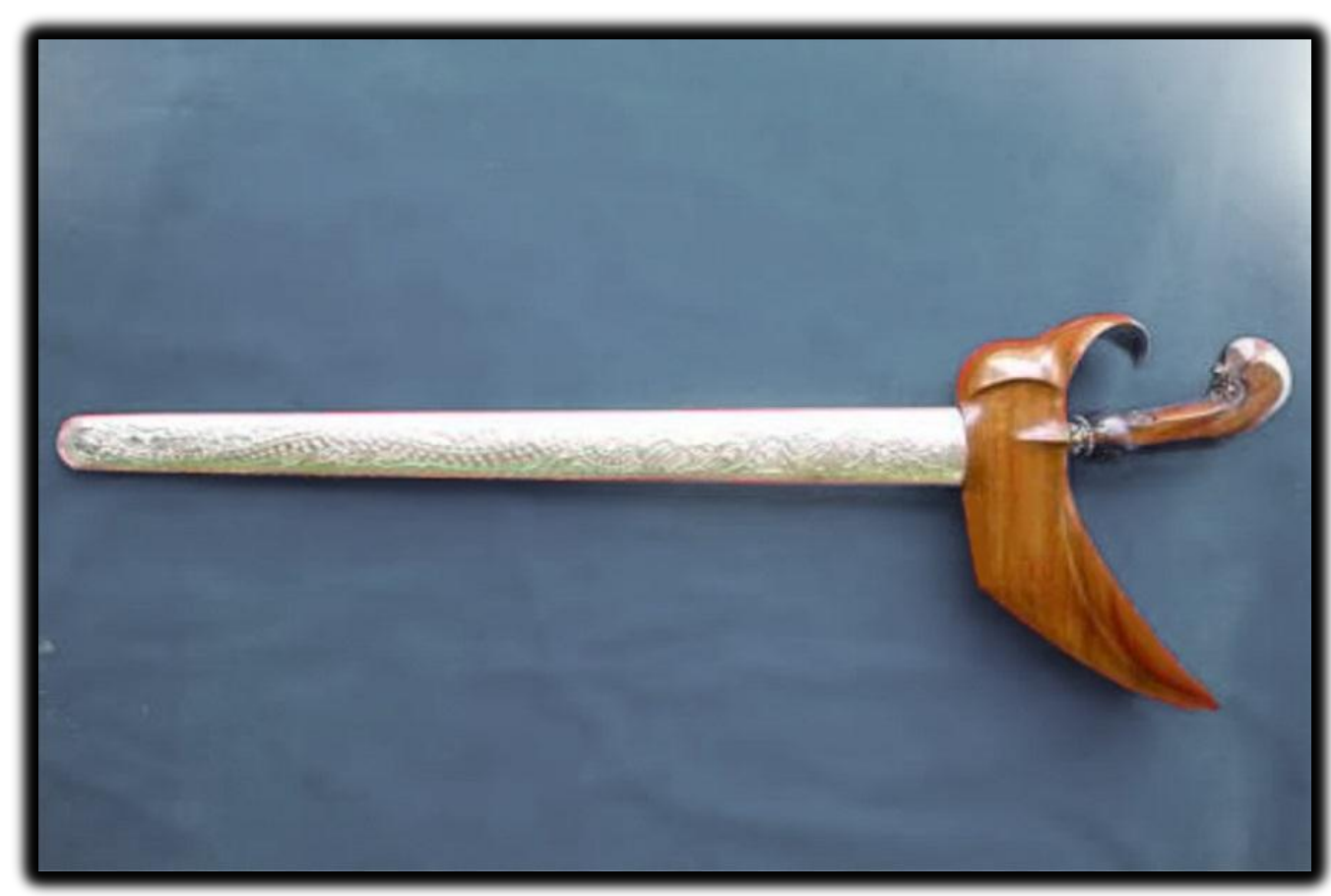

Foto 4.21 Keris

(Dokumentasi: Abrilia, April 2016)

\subsubsection{Pola Lantai}

Pola lantai dan pengolahan ruang tidak diperlukan penggarapan secara cermat mengingat gerak-gerak pada kesenian Barongan bersifat improvisasif. Tempat pementasan juga tidak memerlukan panggung karena Barongan lebih sering memilih lapangan atau halaman terbuka sebagai tempat pementasan. Pola lantai yang digunakan pada pertunjukan kesenian Barongan Wahyu Budaya tergolong desain yang sederhana. Lebih sering menggunakan pola gerak melingkar dan membentuk garis lurus. 
1. Pola Lantai Pertama

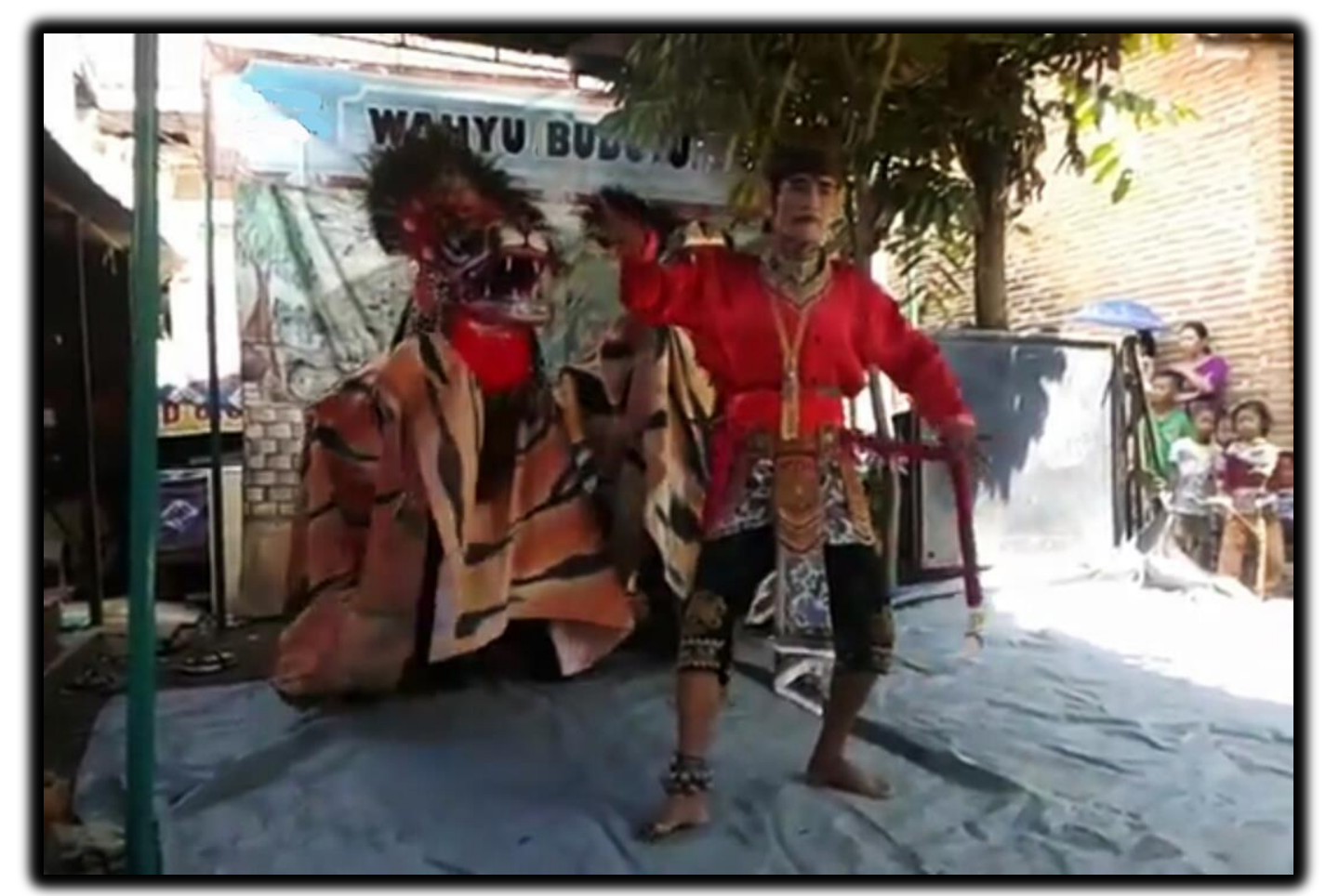

Foto 4.22 Pola Lantai Pertama

(Dokumentasi: Abrilia, April 2016)

Foto 4.22 merupakan pola lantai awal pertunjukan yang menggunakan pola segitiga dengan posisi Penthul berada di bagian depan dan kedua Barongan berada di belakang Penthul. 
2. Pola Lantai ke Dua

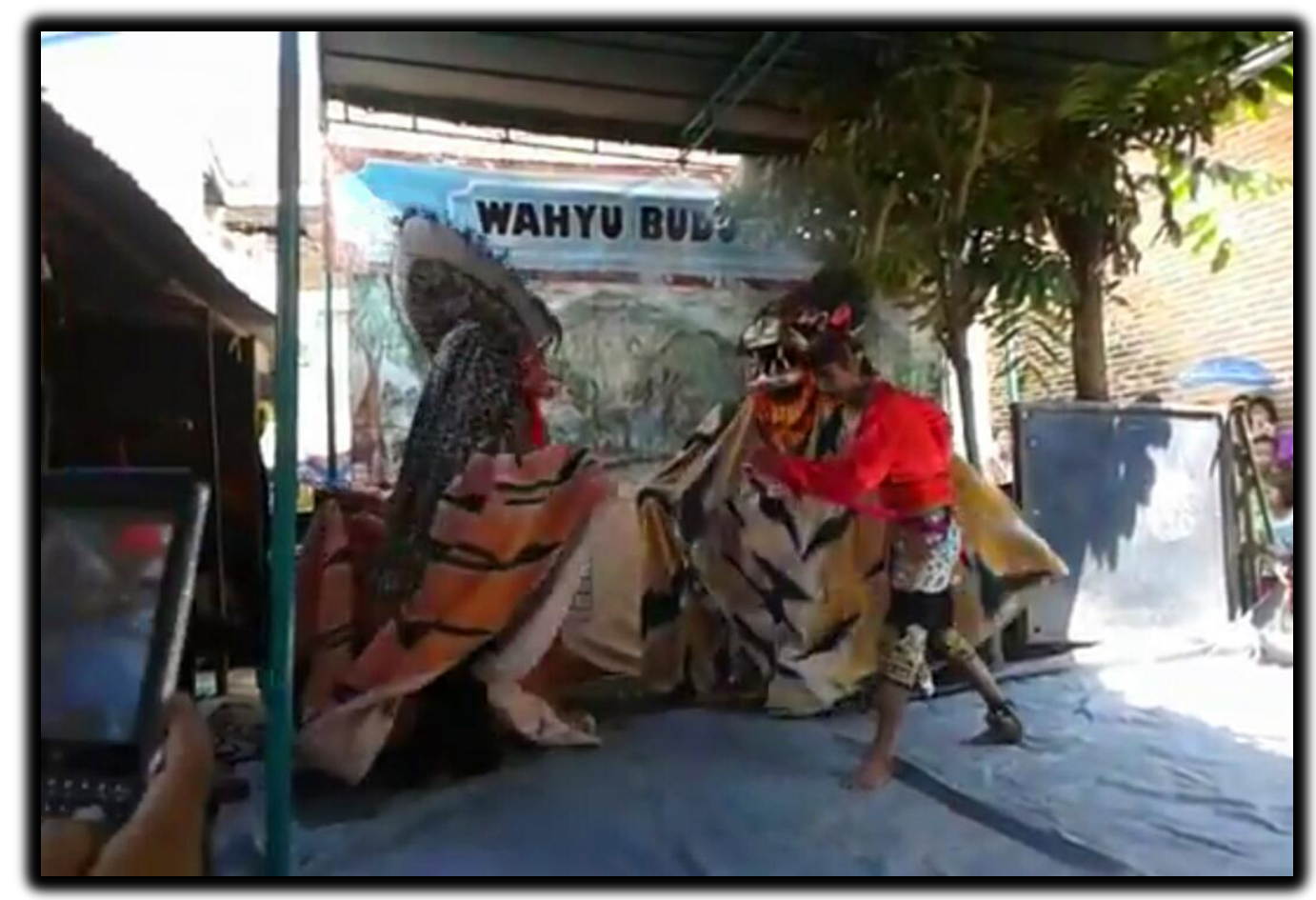

Foto 4.23 Pola Lantai ke Dua

(Dokumentasi: Abrilia, April 2016)

Pola lantai ke dua masih menggunakan pola segitiga namun terdapat perubahan arah hadap. Penthul menghadap ke salah satu sisi sedangkan kedua Barongan saling berhadapan. 
3. Pola Lantai ke Tiga

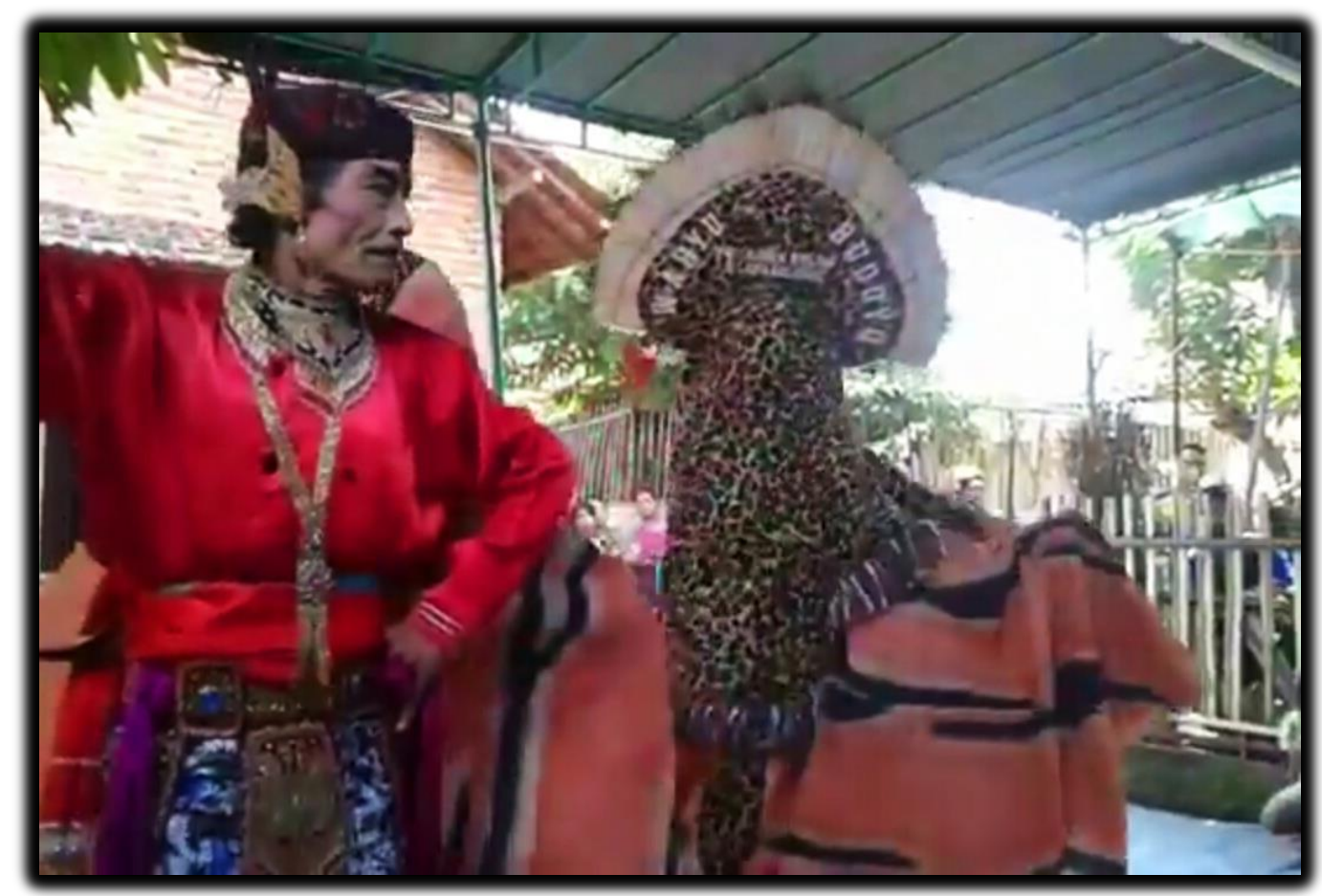

Foto 4.24 Pola Lantai ke Tiga

(Dokumentasi: Abrilia, April 2016)

Pola lantai ke tiga menunjukkan pola garis diagonal yang berarti penari membentuk garis menyudut ke kanan atau ke kiri. Pada pertunjukkan Barongan Wahyu Budaya, pola lantai garis diagonal sering digunakan dengan mengembangkan variasi-variasi arah hadap. Foto 4.24 Penthul dan Barongan berada pada garis garis diagonal dengan variasi arah hadap yang saling membelakangi. 
4. Pola Lantai ke Empat

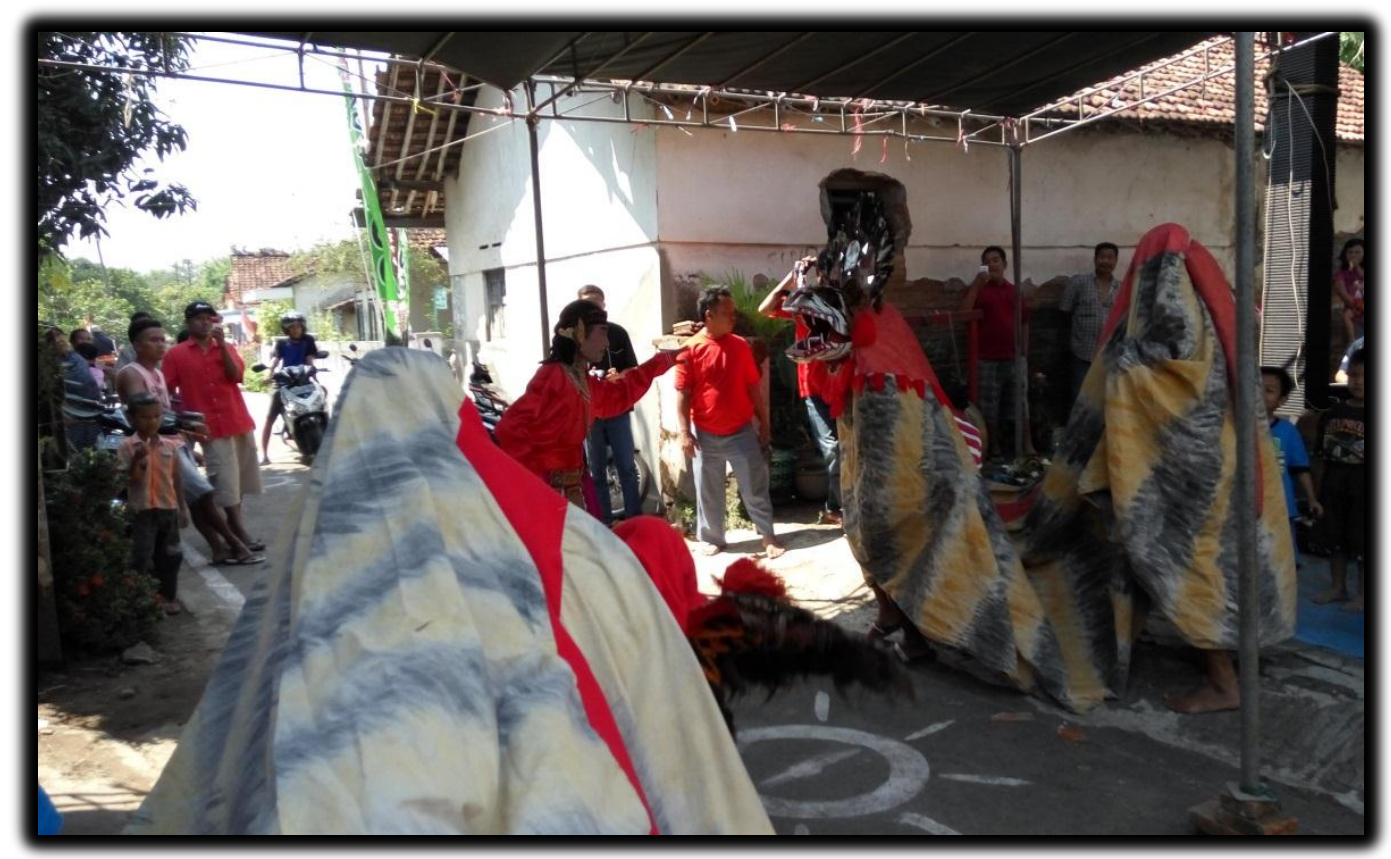

Foto 4.25 Pola Lantai ke Empat

(Dokumentasi: Abrilia, April 2016)

Pola lantai ke Empat adalah pola lantai membentuk lingkaran. Pola lantai berbentuk lingkaran lebih banyak digunakan karena pola lantai melingkar merupakan salah satu ciri-ciri pola lantai dari kesenian rakyat.

\subsubsection{Tempat dan Waktu Pertunjukan}

Tempat pertunjukan merupakan tempat yang digunakan umtuk menggelar suatu pertunjukan atau pementasan. Pertunjukan tari dapat dilakukan di panggung, pendopo dan juga arena. Pada pertunjukan kesenian Barongan Wahyu Budaya dilakukan di halaman terbuka, karena banyak penari serta gerakan yang lincah membuat penari lebih bebas bergerak daripada di panggung atau di ruangan tertutup. 
Dengan digelar di halaman terbuka, maka penonton dapat melihat lebih dekat dan dapat berinteraksi secara langsung dengan para pemain.

Pertunjukan dimulai pada pukul 09.00 sampai 11.30 WIB dengan urutan penyajian yang sudah tersusun. Kemudian pada pukul 13.00 sampai 16.00 dilanjutkan dengan kegiatan arak-arakan mengelilingi desa. Untuk waktu pementasan tergantung dari kebutuhan. Dilaksanakan pada siang hari memiliki fungsi keperluan hajatan atau syukuran. Namun ada juga pementasan yang dilakukan pada malam hari untuk fungsi ritual desa.

\subsubsection{Penonton}

Kedudukan penonton sangat menentukan berhasil atau tidaknya sebuah pertunjukan. Penonton merupakan salah satu komponen yang menentukan, oleh karena itu penonton harus diperhitungkan dalam perencanaan penyajian suatu pertunjukan. Organisasi seni tari yang baik tentu akan melakukan pembinaan penonton dalam arti terus menjalin hubungan atau interaksi positif dengan penontonnya (masyarakat).

Penonton pertunjukan kesenian Barongan Wahyu Budaya berasal dari semua kalangan baik dari anak-anak, dewasa, orang tua, laki-laki, dan juga wanita semua sangat antusias untuk menyaksikan pertunjukan. Pada awal pertunjukan jumlah penonton terhitung masih sedikit, namun setelah beberapa menit pementasan, suasana menjadi riuh ramai pertanda penonton semakin memenuhi arena pementasan 


\subsection{Urutan Penyajian Pertunjukan Barongan Wahyu Budaya}

Urutan penyajian pertunjukan Kesenian Barongan Wahyu Budaya dapat dibagi

menjadi tiga tahapan. Berdasarkan wawancara dengan Bapak Sukadi (April 2016) selaku ketua grup, menjelaskan bahwa urutan penyajian pentas Barongan Wahyu Budaya dimulai dari tahap pembuka, kemudian dilanjut tahap inti dan bagian yang terakhir adalah tahap penutup. Setelah ketiga tahapan selesai, diberikan waktu untuk beristirahat dan nantinya akan dilanjutkan dengan kegiatan arak-arakan menuju rumah warga dalam satu RT.

\subsubsection{Tahap Pembuka (tahap pra tontonan)}

Tahap pembuka dalam pertunjukan kesenian Barongan Wahyu Budaya berupa acara selamatan, merupakan tahap awal yang wajib dilakukan sebelum pertunjukan dimulai. Acara selamatan dilakukan oleh pemilik hajatan yaitu kelompok pemuda GANCO, sesepuh Dukuh Karang Rejo dan seluruh pemain Barongan. Selamatan diharapkan agar seluruh masyarakat Desa Loram Kulon mendapat perlindungan dan dijauhkan dari marabahaya serta untuk kelancaran pertunjukan. Dalam acara selamatan tersaji berbagai jenis makanan seperti nasi tumpeng lengkap dengan lauk pauknya beserta ayam ingkung. Ingkung adalah salah satu uborampe berupa ayam kampung yang dimasak utuh dan diberi bumbu opor, kelapa dan daun salam. Ingkung melambangkan bayi yang baru dilahirkan, dengan demikian belum mempunyai dosa atau masih suci. Sehingga dengan adanya ayam ingkung diharapkan seluruh masyarakat Desa Loram bersih dan suci seperti bayi yang baru dilahirkan. 
Pertunjukan Barongan dilaksanakan di halaman rumah Bapak Da'im RT. 02 RW. I No. 32 Loram Kulon difungsikan sebagai sarana hiburan dalam rangka syukuran rutin atas keberhasilan beberapa kegiatan yang telah dilakukan sebelumnya. Hiburan Kesenian Barongan diadakan oleh kelompok anak muda Desa Loram (kelompok GANCO) yang ditujukan untuk seluruh warga baik dari dalam Desa Loram Kulon maupun dari luar Desa Loram Kulon. Acara dimulai dari jam 09.00 WIB sampai selesai. Bunga menjadi syarat sesaji sederhana telah dipersiapkan dan dibacakan doa oleh pawang Barong.

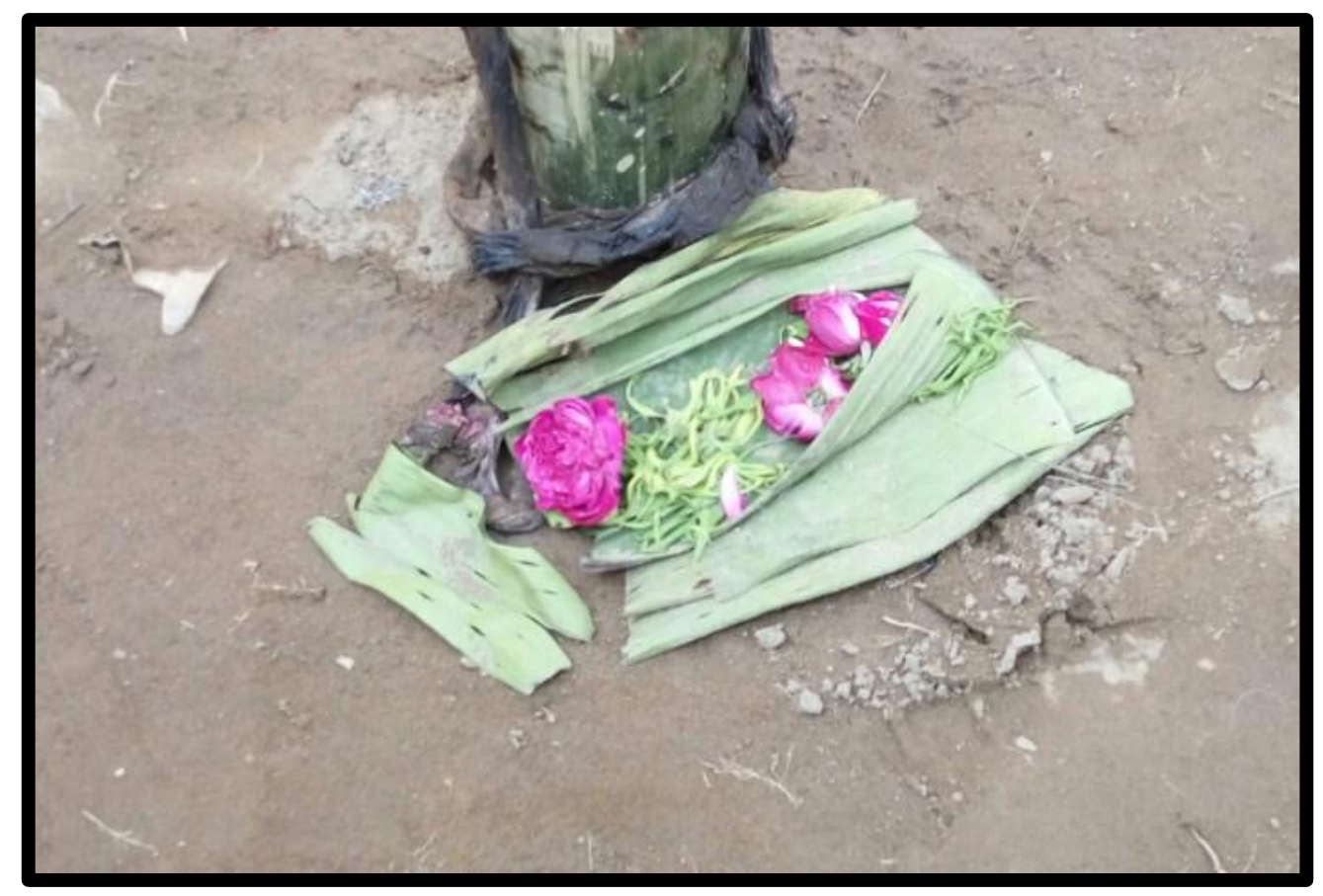

Foto 4.26 Kembang Telon yang sudah dibacakan mantra (Dokumentasi: Abrilia, April 2016)

Foto 4.26 merupakan bentuk sesaji sederhana berupa bunga mawar, bunga kanthil dan bunga kenanga yang sudah dibacakan mantra oleh Bapak Karmin 
sebelum pertunjukan dimulai. Kembang Telon berupa sesaji diharapkan supaya meraih tiga kesempurnaan dan kemuliaan hidup (tri tunggal jaya sampurna). Sugih bandha, sugih ngelmu, sugih kuasa, artinya kaya harta, kaya ilmu dan kaya kekuasaan. Penonton yang sebagian besar merupakan orang Jawa, percaya pada suatu kekuatan dari arwah atau roh leluhur yang menempati sekitar tempat tinggal manusia. Sesaji yang dikenal dengan sebutan sesajen sudah sangat melekat dalam kehidupan masyarakat muslim di berbagai daerah.

Tahap pembuka dalam kesenian Barongan Wahyu Budaya merupakan tahapan awal sebagai pertanda akan segera dimulainya pertunjukan Barongan. Langkah pertama setelah acara selamatan dan makan bersama, yang dilakukan adalah pembacaan doa bersama-sama dipimpin oleh ketua grup (Bapak Sukadi) dengan mengucap salam dan Basmalah dengan tujuan memohon keselamatan serta kelancaran kepada Yang Maha Kuasa agar pertunjukan berjalan tanpa halangan dari awal hingga akhir. Di sela pembacaan doa, sang pawang mulai membakar kemenyan. Selain ditujukan kepada Sang Pencipta, menurut Bapak Karmin (pawang Barongan), pembacaan do’a juga ditujukan kepada roh para leluhur di Desa yang bersangkutan.

Setiap agama itu memiliki caranya masing-masing dalam berdoa mbak. Mung kabeh tergantung niate. Karek piye awake dewe iki menilai. Orang Jawa harus percaya dengan adat Jawa termasuk setiap melakukan acara seperti ini harus membakar menyan. Selain yang utama kita meminta kepada Gusti Allah juga nyuwun karo sing mbahurekso deso iki. Istilahe kulanuwun arep nganakno acara, nyuwun diparingi kelancaran. Saya juga pernah pentas di daerah Kandang Mas itu kepercayaannya malah lebih njawani. Sesepuh di sana meling, sak durunge main salah siji Barongane digowo ning punden disik, nek kangelan salah siji alat musikke digowo rono tak raupane banyu sumber. 
(Setiap agama itu memiliki caranya masing-masing dalam berdoa mbak. Hanya saja semua tergantung dari niatnya. Tinggal bagaimana diri kita menilai. Orang Jawa harus percaya dengan adat Jawa termasuk setiap melakukan acara seperti ini harus membakar kemenyan. Selain yang utama kita meminta kepada Yang Maha Kuasa, juga meminta kepada roh leluhur di desa ini. Istilahnya ijin permisi akan mengadakan acara, minta agar diberi kelancaran. Saya juga pernah pentas di daerah Kandang Mas itu kepercayaannya malah lebih kolot lagi. Sesepuh di sana memberi pesan, sebelum pentas salah satu Barongan dibawa ke punden dulu, kalau dirasa susah salah satu alat musiknya dibawa ke sana biar saya lap menggunakan mata air).

\subsubsection{Tahap Inti}

Tahap inti dari pertunjukan Barongan merupakan tahapan yang paling ditunggu oleh masyarakat yang sedang berada di lokasi pementasan. Pertunjukan Barongan dalam tahap inti terdiri dari tiga babak. Untuk keterangan yang lebih jelas, maka penulis akan menguraikan alur cerita sesuai dengan urutan penyajian yang telah disaksikan. Tiga babak pertunjukan inti Barongan adalah sebagai berikut:

\subsubsection{Gending Pembukaan}

Mengalunnya gending mengiringi pertunjukan Barongan disertai dengan beberapa lagu yang dinyanyikan oleh penyanyi laki-laki menandakan telah dimulainya pementasan. Pada awal pembukaan ini, lagu yang dibawakan masih berjenis langgam-langgam Jawa.

\subsubsection{Babak I}

Pawang mulai memasuki arena pementasan merupakan bagian dari babak pertama setelah musik pengiring mengalun. Saat Pawang melangkah ke tengah arena pertunjukan, melakukan adegan sembahan dan mulai menari, seperti memiliki daya 
tarik tersendiri bagi penonton untuk mendekati arena pementasan. Banyak penonton dari berbagai kalangan mulai anak kecil hingga orang tua cukup memadati lokasi di depan rumah Bapak Da'im. Mereka sangat antusias menyaksikan pertunjukan Barongan walaupun dapat dikatakan kesenian Barongan bukan hiburan yang asing lagi bagi masyarakat sekitar.

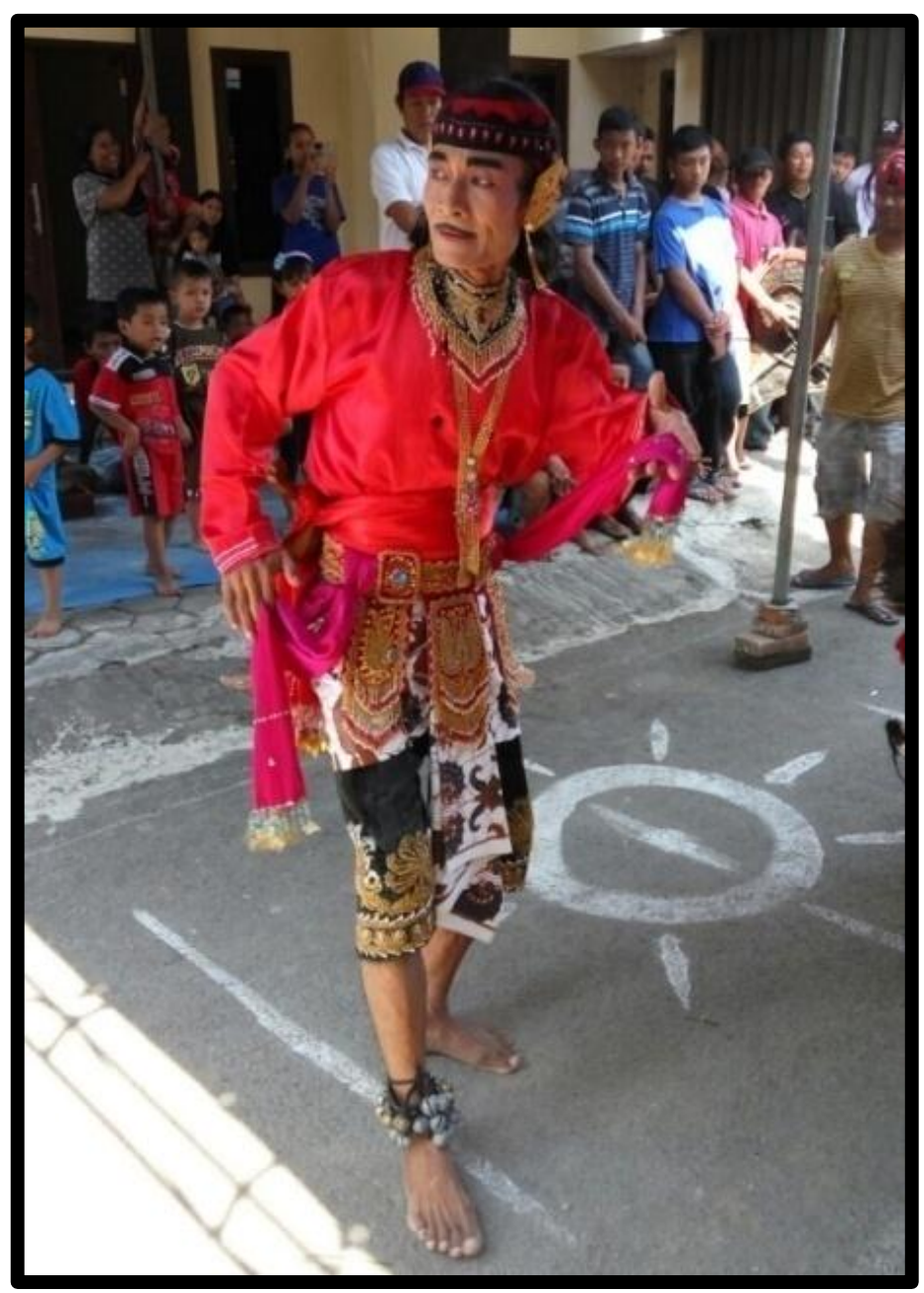

Foto 4.27 Pawang menari di tengah arena pertunjukan (Dokumentasi: Abril, April 2016) 
Pawang Barongan yang ada pada foto 4.27 menjelaskan peranannya sebagai Penthul sudah mengalami banyak perubahan dalam segi kostum yang dikenakan. Wawancara dengan Bapak Karmin (April 2016), beliau memberikan gambaran tentang peran Penthul terdahulu sebenarnya memakai topeng berwarna merah atau hitam, berhidung besar panjang dengan mata bulat seperti sedang melotot dan memiliki rambut tebal terurai panjang. Namun seiring dengan perkembangan kesenian Barongan yang ada di Kudus, maka peran Penthul sekarang cukup menggunakan kostum tari yang biasanya berwarna terang seperti merah dan ada pula yang berwarna kuning serta menggunakan rias wajah sederhana seperti yang terlihat pada foto 4.10

\subsubsection{Babak II}

Bagian inti pertunjukan selanjutnya setelah Penthul melakukan gerakangerakan tari sederhana kemudian disusul dengan masuknya dua Barongan yaitu Macan Barong dan Singa Barong yang tiap Barongnya dimainkan oleh dua orang penari. Gerakan yang ditarikan oleh pembarong Wahyu Budaya tidak memiliki gerakan terstruktur. Menurut keterangan Eko Wahyudi (21 tahun) sebagai pembarong utama menyebutkan beberapa gerakan-gerakan utama yang ditarikan saat pementasan antara lain gerakan ngaklak, caplokan, ndekem, glundungan. Sedangkan untuk gerakan yang lainnya, Eko menggunakan gerakan eksplorasi yang sudah sering dilakukan pada saat latihan maupun pada pementasan sebelumnya.

Barongan menari bersama Penthul mengelilingi arena pementasan masih menunjukkan suasana damai. Pada saat Barongan menari, terkadang diselingi 
interaksi kepada penonton dengan menakut-nakuti anak kecil yang berada di sekitar arena. Barongan membuka lebar mulutnya di depan anak-anak kecil sehingga terdengar riuh teriakan penonton berusaha untuk menghindar. Gerakan Barongan yang membuka lebar mulutnya sebagai perlambang ingin memakan anak tersebut.

\subsubsection{Babak III}

Setelah beberapa menit berlangsung, tiba-tiba Barongan menari dengan buas dan tidak terkendali berusaha menyerang Penthul. Pada tahap inti inilah pertarungan antara Penthul melawan Barongan terjadi yang pada akhirnya pertarungan dimenangkan oleh Penthul. Barongan menyerah kalah kemudian meminta syarat untuk dibakarkan kemenyan. Barongan segera menghirup asap kemenyan itu agar Barongan bisa tenang dan dikendalikan oleh sang pawang.

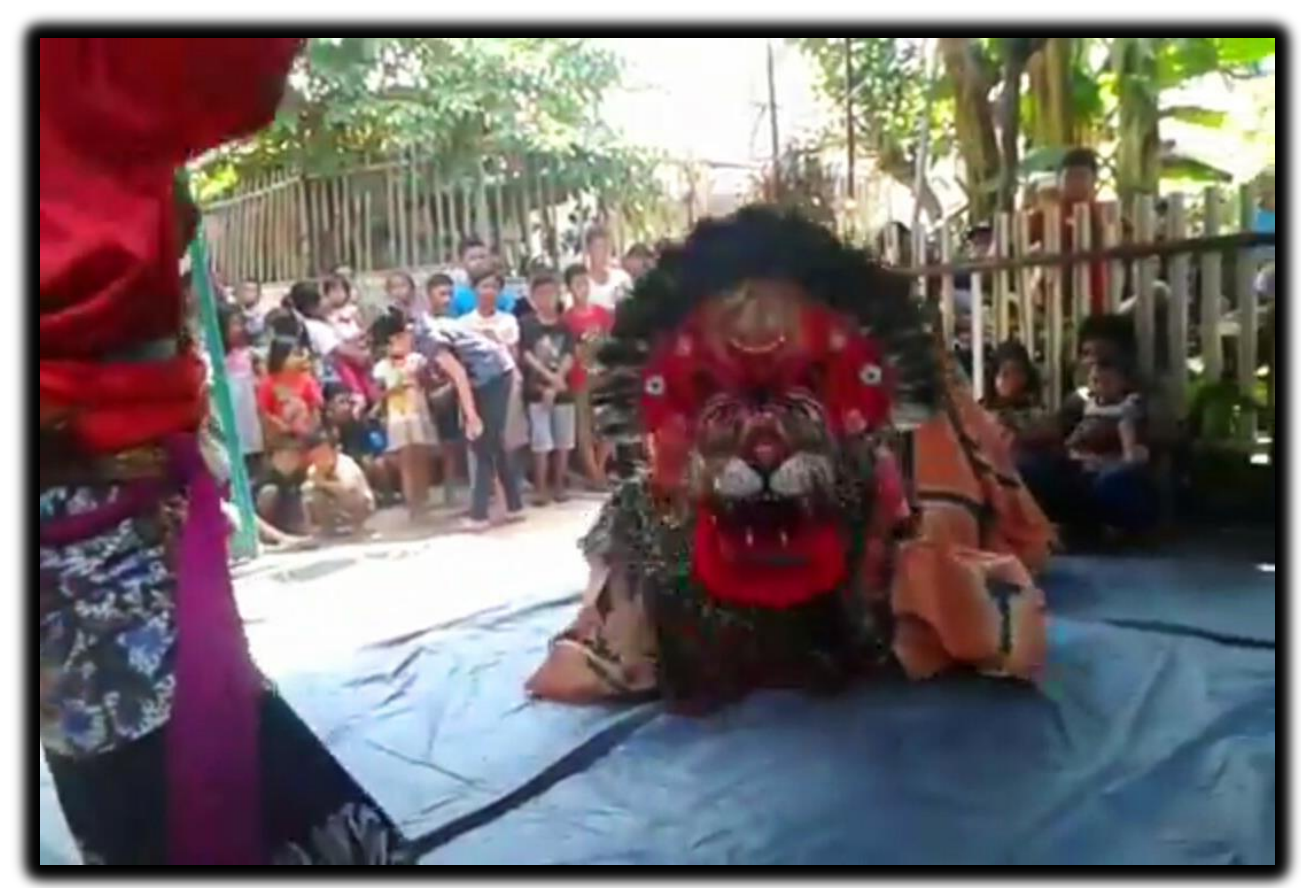

Foto 4.28 Barongan ditundukkan oleh Penthul (Dokumentasi: Abrilia, April 2016) 


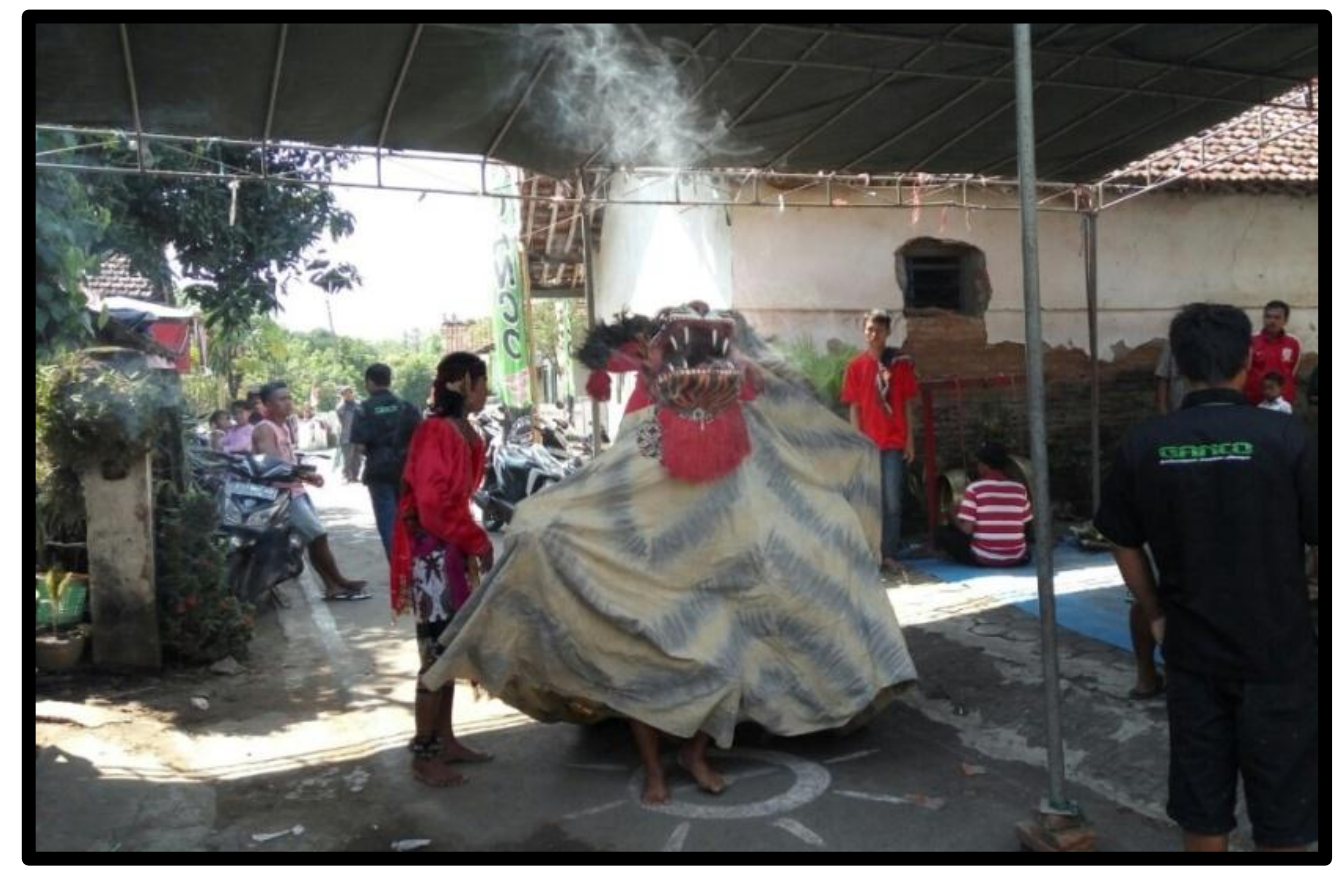

Foto 4.29 Barongan menghirup asap kemenyan

(Dokumentasi: Abrilia, April 2016)

\subsubsection{Tahap Penutup}

Tahap akhir pertunjukan Barongan ditutup dengan tembang-tembang Jawa dan lantunan doa yang dibacakan sang Pawang sebagai simbol penghormatan serta ucapan terimakasih kepada Yang maha Kuasa, juga kepada penyelenggara hiburan. Kemudian dilanjutkan dengan tarian Kuda Lumping yang ditarikan oleh beberapa anggota kelompok anak muda GANCO. Pada saat Kuda Lumping menari, terkadang diselingi dengan masuknya penari lain yang menggunakan topeng Bondet. Menurut keterangan Bapak Karmin (pawang), mengatakan biasanya untuk acara ruwatan atau yang bersifat lebih resmi, Bondet ikut menari di belakang Barongan, namun untuk acara hiburan, peran Bondet hanya sebagai pelengkap saja. 


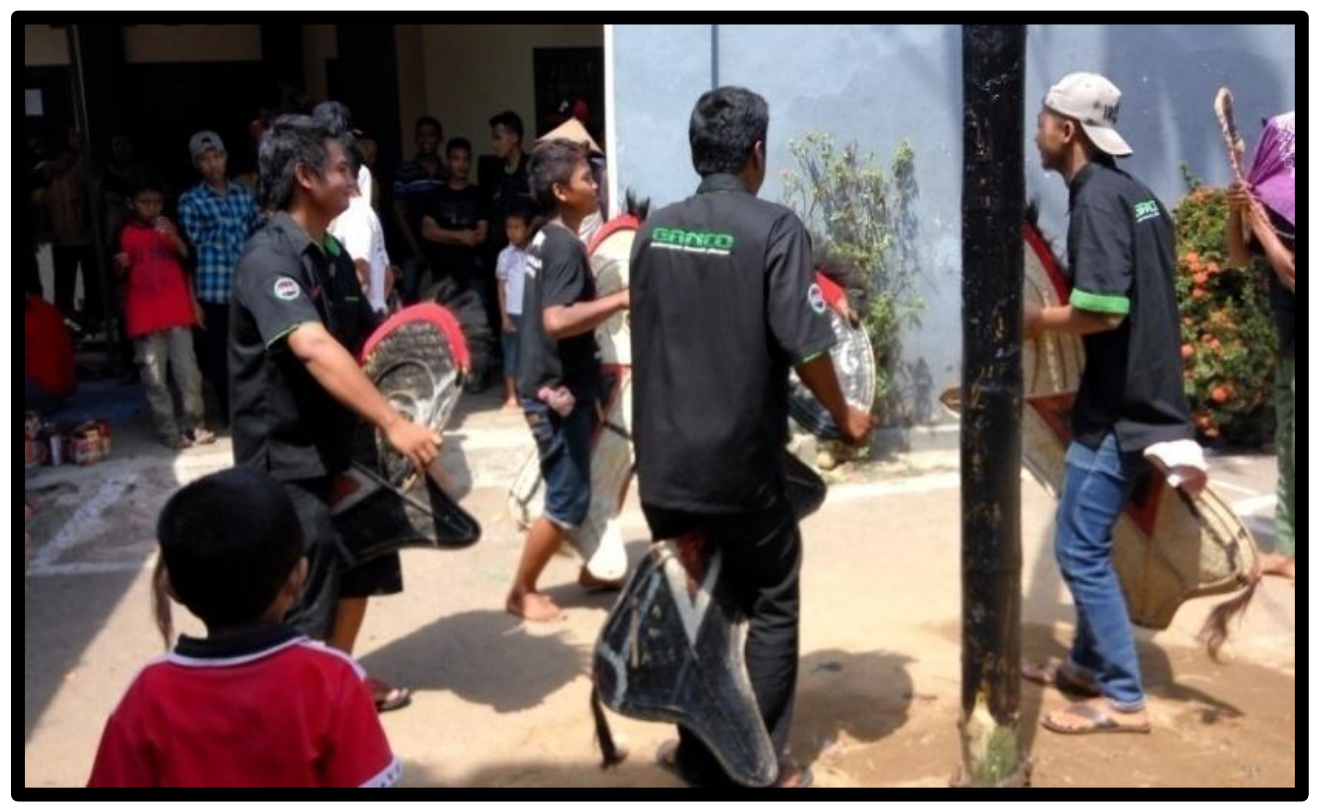

Foto 4.30 Kesenian Kuda Lumping (Dokumentasi: Abrilia, April 2016)

Peranan Kuda Lumping dalam sejarah cerita Barongan di Kudus merupakan pengiring yang menjadi simbol kekuatan dari Gembong Kamijoyo. Tarian Kuda lumping pada pementasan ini tidak menggunakan pola lantai yang tersusun rapi. Gerakan hanya menirukan pasukan yang sedang menunggang kuda. Selalu ada interaksi antara pemain dengan penonton. Terkadang seorang pemain yang sedang pentas dapat digantikan oleh pemain lain ataupun masyarakat yang berada di lokasi pementasan apabila pemain tersebut kelelahan. Yang lebih dipentingkan dalam kesenian Barongan sebagai fungsi hiburan adalah memberikan kepuasan kepada penonton.

Pertunjukan Kuda Lumping seringkali menampilkan para pemain yang mengalami kerasukan. Namun pada pementasan kali ini tidak menampilkan atraksi- 
atraksi kerasukan ataupun mempertontonkan kekuatan mistis seperti yang dipentaskan pada kesenian Jaran Dor. Hanya saja menurut pengakuan dari para pemain Kuda Lumping, mereka tidak merasakan sakit walaupun berkali-kali pecutan mengenai bagian tubuh pemain dikarenakan sudah dibacakan mantra oleh sang pawang.

\subsubsection{Arak-arakan Barongan Wahyu Budaya}

Pertunjukan kesenian Barongan Wahyu Budaya yang diselenggarakan oleh pemuda Desa Loram Kulon selain sebagai fungsi hiburan juga dijadikan sebagai fungsi ekonomi. Terlihat dari susunan acara setelah prosesi dari setiap tahap penyajian usai, maka diadakan arak-arakan mengelilingi rumah warga terdekat atau masyarakat lebih mengenal dengan sebutan ngarak. Arak-arakan dilaksanakan sekitar pukul 13.00 WIB, diawali berangkat dari rumah Bapak Da'im menuju rumahrumah warga dan tujuan terakhir adalah rumah Bapak Tejo selaku ketua RW I Desa Loram Kulon. 


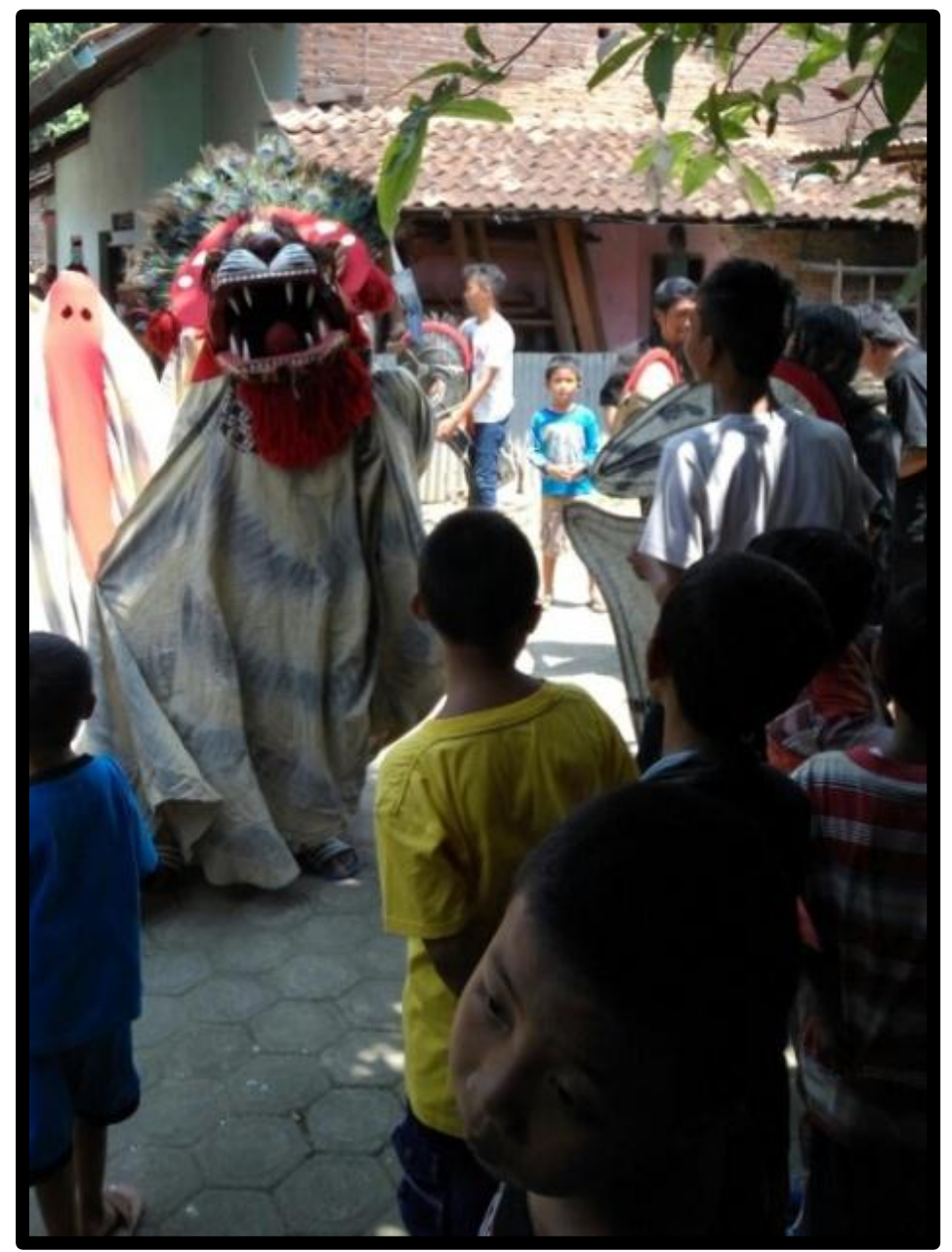

Foto 4.31 Arak-arakan Barongan Wahyu Budaya (Dokumentasi: Abrilia, April 2016)

Foto 4.31 menunjukkan arak-arakan yang dilakukan oleh Barongan Wahyu Budaya di depan rumah Bapak Tejo Ketua RW I Desa Loram Kulon sebagai tempat tujuan terakhir dari kegiatan arak-arakan. Menurut Bapak Sukadi (ketua grup) menerangkan alasan ngarak terakhir dipilih untuk mengunjungi rumah ketua RW I dikarenakan biasanya sebagai pimpinan dalam suatu desa, ketua RT maupun ketua RW telah mempersiapkan jamuan berupa makanan dan minuman untuk para pemain Barongan. 
Sebuah kaleng yang dibawa oleh seorang pemain Barongan menjadi simbol sukarela dari masyarakat untuk memberikan sejumlah uang, yang nantinya akan menjadi tambahan pendapatan bagi para pemain.

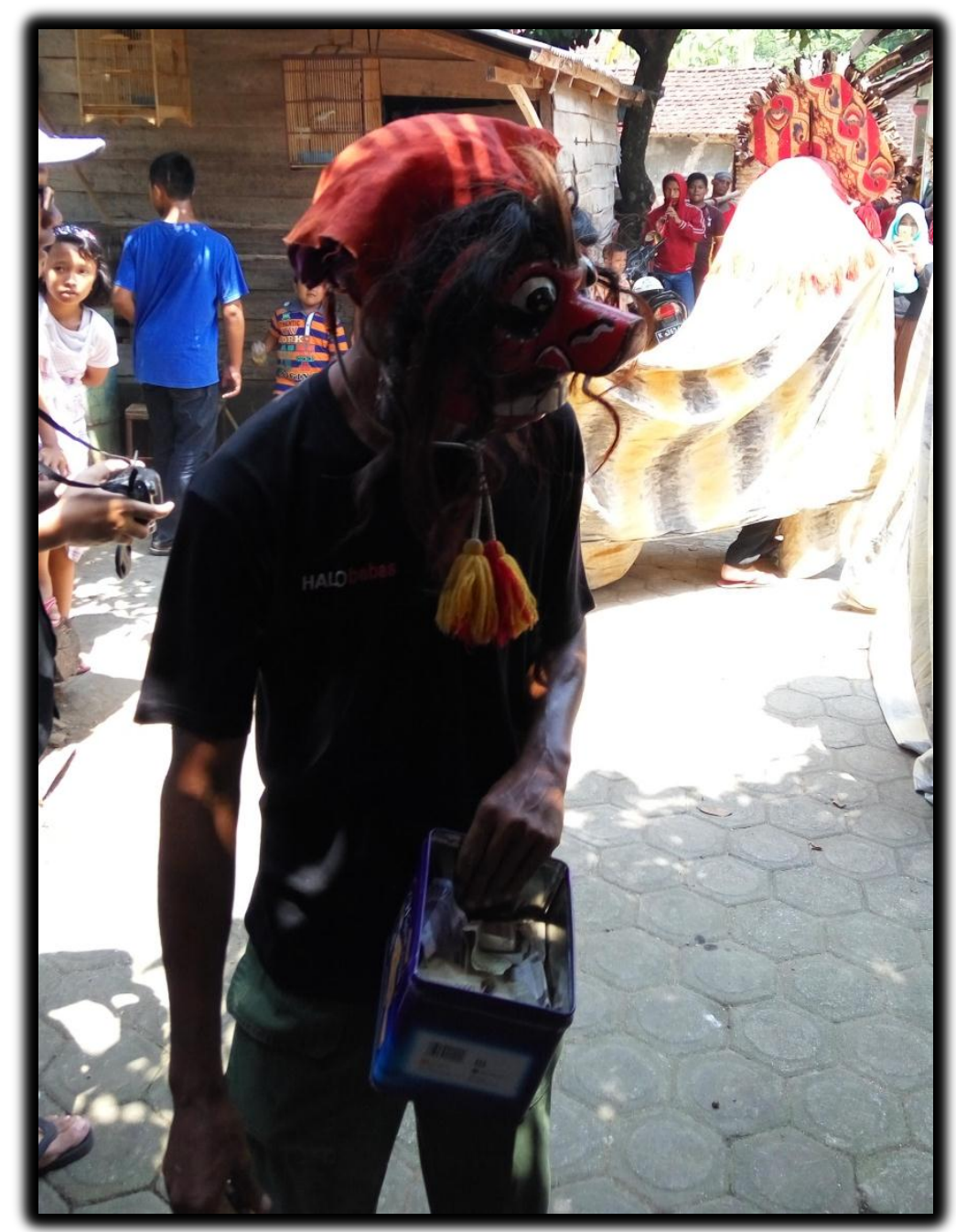

Foto 4.32 Bondet membawa kaleng tempat sumbangan warga (Dokumentasi: Abrilia, April 2016)

Foto 4.32 adalah pemeran Bondet yang bertugas membawa kaleng sebagai tempat uang sumbangan dari warga atau penonton yang ingin memberikan uang di lokasi arak-arakan. Terkadang Bondet juga bertingkah laku lucu dengan menggoda 
para penonton, menari-nari kemudian duduk di pelataran dan merengek sambil mengulurkan kaleng bermaksud agar ada penonton yang bersedia memberikan sejumlah uang untuk pemain Barongan. Kelucuan Bondet dapat dilihat pada foto 4.33

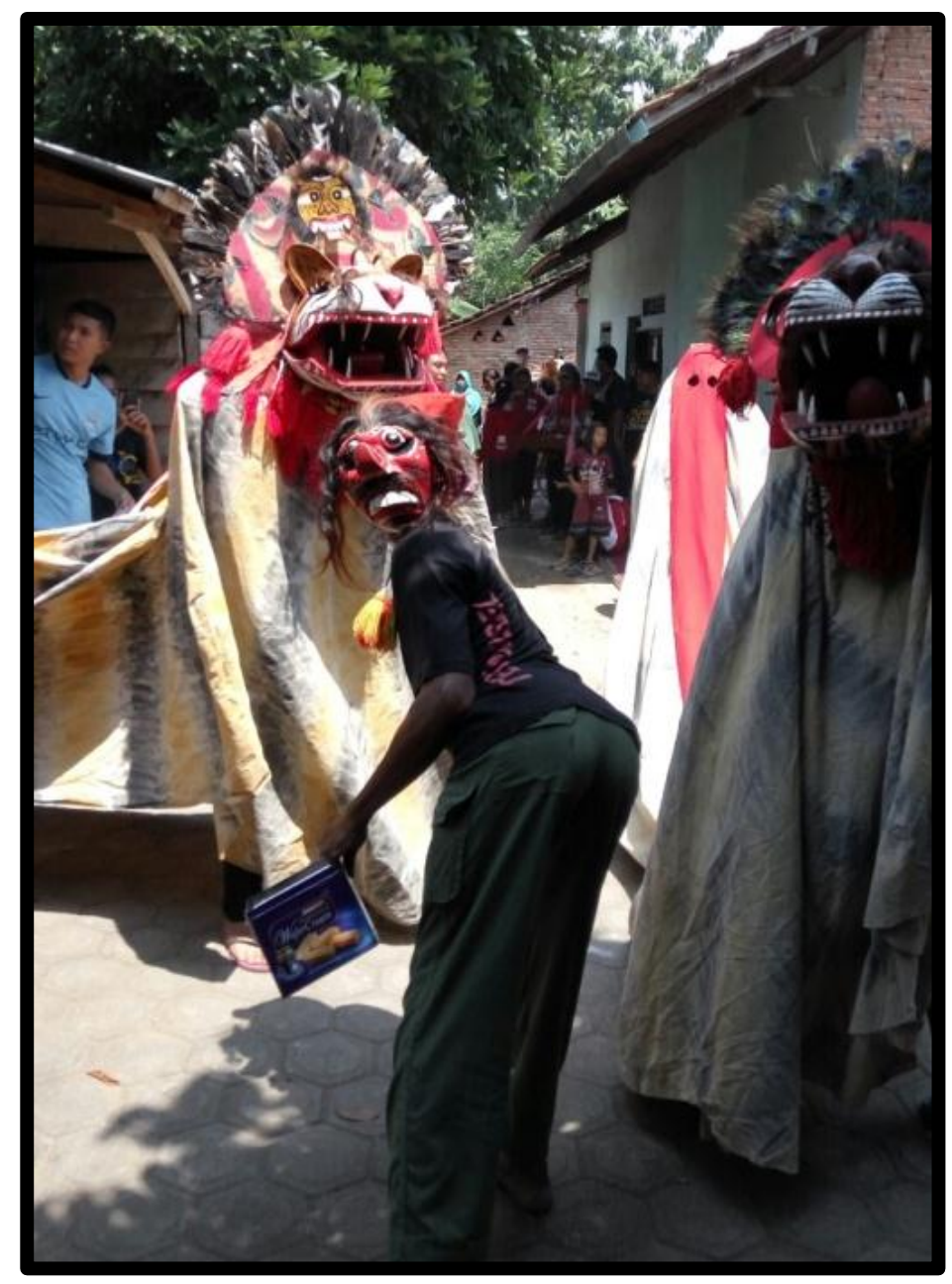

Foto 4.33 Bondet bertingkah laku lucu untuk menarik perhatian penonton (Dokumentasi: Abrilia, April 2016)

Sumbangan tidak hanya diberikan oleh penonton (warga) dengan cara memasukan uang ke dalam kaleng. Namun ada juga yang mengikat uang di pohon seperti yang dilakukan oleh Bapak Tejo (Ketua RW) agar Barongan mengambilnya 
dengan cara mencaplok uang tersebut menggunakan mulutnya. Menurut keterangan Bapak Sukadi (Ketua Grup) menjelaskan apabila uang tersebut digantung dan diambil oleh Barongan maka uang itu menjadi rejeki sang pemeran Barong. Artinya tidak bagi rata dengan pemain lainnya. Yang dibagi adalah uang yang didapat oleh Bondet. Bukan menjadi masalah ataupun menjadikan iri terhadap sesama pemain dikarenakan pemain yang lain merasa pembarong utama memiliki beban yang lebih berat dibanding dengan lainnya.

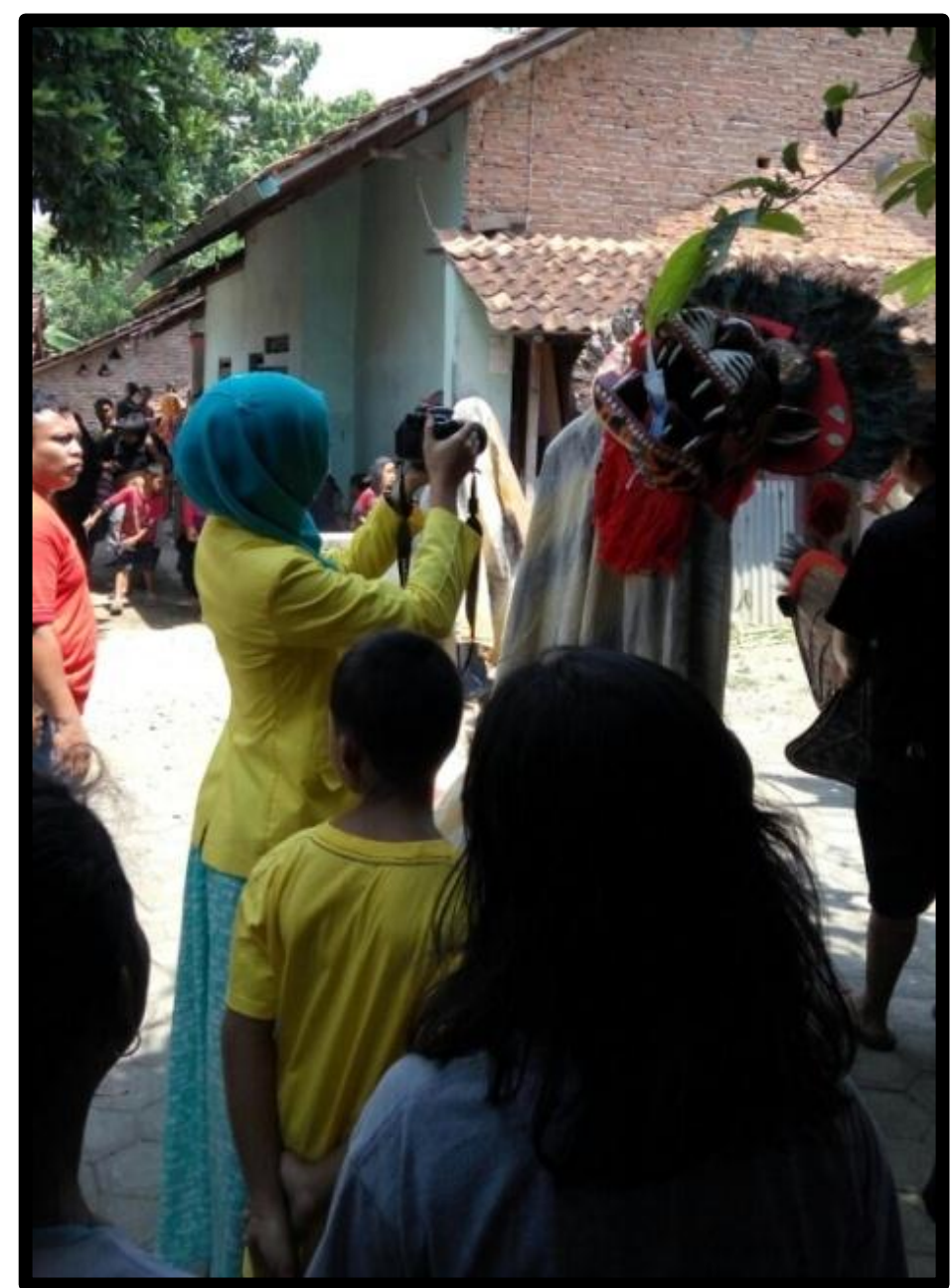

Foto 4.34 Barongan sedang mencaplok uang yang tergantung di pohon (Dokumentasi: Abrilia, April 2016) 


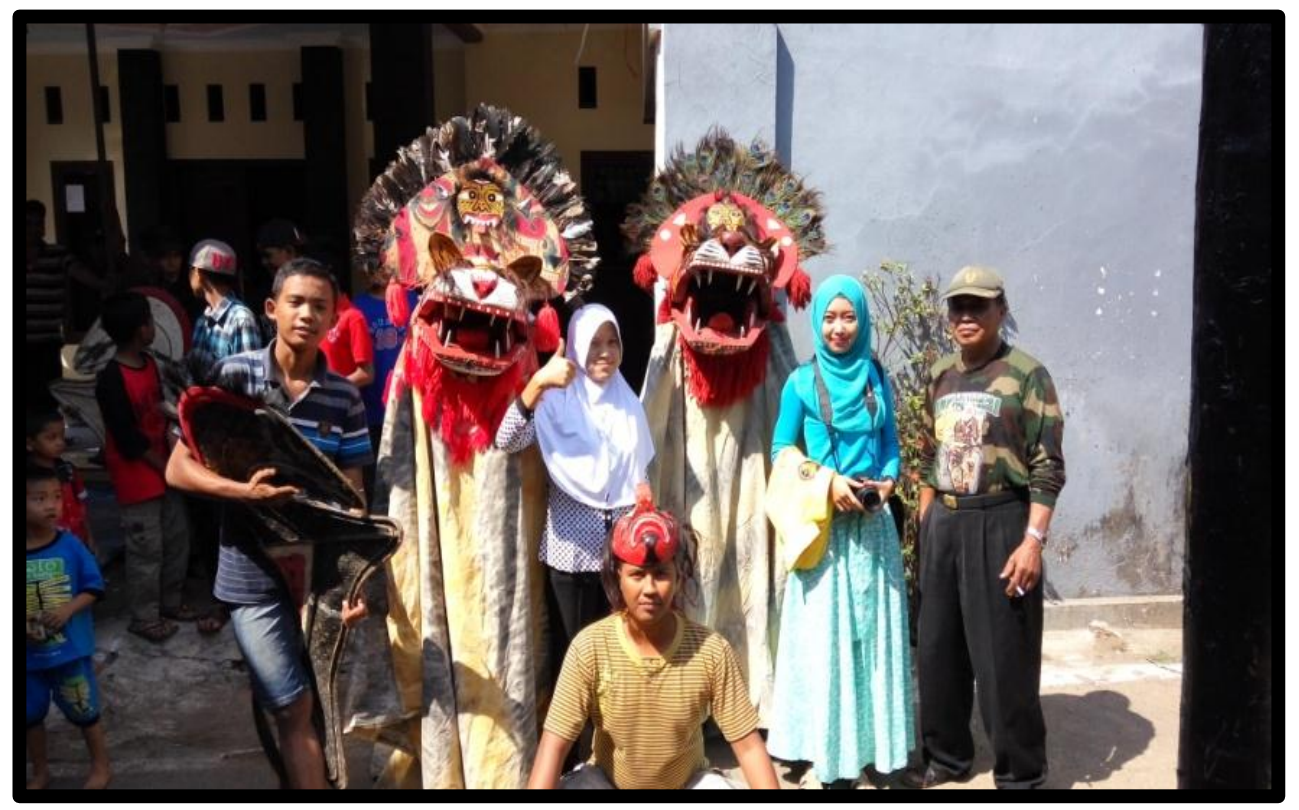

Gambar 4.35 Peneliti bersama dengan pemain Barongan (Dokumentasi: Abrilia, April 2016) 


\section{BAB V}

\section{PENUTUP}

\subsection{Simpulan}

Berdasarkan hasil penelitian mengenai bentuk pertunjukan kesenian Barongan Wahyu Budaya di Dukuh Karang Rejo Desa Loram Kulon Kecamatan Jati Kabupaten Kudus, maka penelitian ini dapat disimpulkan sebagai berikut:

Bentuk pertunjukan kesenian Barongan Wahyu Budaya memiliki tiga tahap penyajian yaitu 1). Tahap pra tontonan, dimulai dari iringan musik yang mulai ditabuh sebagai pertanda pertunjukan akan segera dimulai, 2). Tahap pementasan, dimulai dari adegan sesembahan kemudian dilanjutkan pada pertunjukan inti yaitu adegan Barongan, dilanjutkan dengan adegan Jaran kepang dan penutup, 3). Arakarakan, dilaksanakan setelah acara inti selesai sekitar pukul 13.00 dan dimulai dari tempat awal pertunjukan kemudian rute selanjutnya adalah mengelilingi desa dengan tujuan akhir di rumah Bapak RT/RW.

Gerakan yang digunakan pawang dalam pementasan sangat sederhana, meliputi gerakan Gedrug, Klebatan Sampur, Tepisan, Klepatan, Pancalan. Kemudian gerakan dari Barong utama adalah Ngaklak, Caplokan, Ndekem, dan Gulundungan. Gerakan tersebut dilakukan pada acara inti pementasan, sedangkan untuk acara arak-arakan hanya menggunakan gerakan-gerakan kecil seperti Ngaklak sambil menggelengkan kepala Barong ke arah kanan dan kiri dengan berjalan menuju rumah warga diiringi musik gamelan tanpa gong yang dipimpin oleh pawang. Pada kegiatan arak-arakan memiliki fungsi ekonomi bagi para pemain 
karena pemain pelengkap yaitu Bondet membawa kaleng yang berfungsi untuk menerima sejumlah uang pemberian dari penonton dan warga yang rumahnya didatangi oleh Barongan.

Iringan musik dengan tempo cepat serta aksen hentakan kendang ditambah irama yang dihasilkan dari alat musik slompret menjadi ciri khas tersendiri yang membedakan kesenian Barongan dengan kesenian yang lain. Gerakan kesenian Barongan sangat rancak, lincah dan atraktif. Untuk rias wajah Penthul menggunakan rias wajah prengesan sedangkan untuk pemain yang lain menggunakan topeng. Busana dan perlengkapan yang digunakan Penthul meliputi iket, sumping, baju hem (baju kurung), kace, sabuk bara-bara dan epek timang, jarik supit urang, sampur, celana panji.

\subsection{Saran}

Saran yang dapat dijadikan pertimbangan bagi Kesenian Barongan di Kudus terutama Barongan Wahyu Budaya adalah sebagai berikut:

1. Bagi Dinas Pariwisata dan Kebudayaan Kabupaten Kudus, diharapkan agar lebih sering menampilkan kesenian Barongan pada setiap acara besar yang dilaksanakan supaya banyak masyarakat dari dalam kota maupun dari luar kota dapat menyaksikan kesenian Barongan Kudus serta mengakui adanya kesenian Barongan sebagai wujud warisan budaya dari pimpinan kota Kudus terdahulu.

2. Bagi Grup Kesenian Barongan Wahyu Budaya agar lebih giat dalam berlatih. Menciptakan generasi baru penerus kesenian Barongan agar tetap lestari serta 
mengembangkan bentuk-bentuk dari gerakan, kostum, dan lain sebagainya tanpa meninggalkan keaslian bentuk Barongan yang sudah ada.

3. Bagi masyarakat baik warga asli dari Desa Loram Kulon maupun luar Desa Loram Kulon sebaiknya ikut menjaga dan melestarikan kesenian Barongan Kudus dengan cara berpartisipasi memeriahkan setiap pertunjukan serta mengakui kesenian Barongan Kudus sebagai cikal bakal terwujudnya Kota Kudus yang berkembang menjadi masyarakat muslim melalui kesenian Barongan. 


\section{REFERENCES}

Andeslo. 2012. Peta Desa Loram Kulon. Diunduh di http: //www.andeslopedesaan.blogspot.co.id.html. Diunduh 21 Agustus 2016 pkl 00.11

Arikunto, Suharsimi. 1998. Metode Penelitian (Pendekatan Penelitian. Jakarta: Rineka Cipta

Arikunto. 2006. Prosedur Penelitian Suatu Pendekatan Praktek. Jakarta: Rineka Cipta

Astini, Siluh Made. 2003. Simbol Barong Dalam Kehidupan Sosial-Religius Umat Hindu di Bali. Semarang Harmonia Vol. IV No.2/Mei-Agustus. Semarang Unnes

Bastomi, Suwaji. 1998. Wawasan Seni. IKIP Semarang Press

Cahyono, Agus. 2002. Ekstensi Tayub dan Sistem Transmisinya.Yogyakarta: Yayasan Lentera Budaya

Djelantik, A. A. M. 1999. Estetika Sebuah Pengantar. Bandung: Masyarakat Seni Pertunjukan Indonesia

Ellfeldt, Lois. 1977. Pedoman Dasar Penata Tari. Terjemahan Sal Murgiyanto. Jakarta: Lembaga Kesenian Jakarta

Esterberg, Kristin. G. 2002. Qualitative Methods in Social Research. New York: Mc. Graw Hill

Hidayat, Robbi. 2015. Wawasan Seni Tari. Pengetahuan Praktis Bagi Guru Seni Tari. Malang: Jurusan Seni dan Desain Fakultas Sastra Universitas Negeri Malang dengan Unit Pengembangan Profesi Tari

Hadi, Sumandiyo. 1996. Aspek-aspek Dasar Koreografi Kelompok. Yogyakarta: Manthili Yogyakarta

Hadi, Sumandiyo. 2003. Mencipta Lewat Tari. Yogyakarta: ISI

Ika, Cicilia. 2006. Bentuk dan Fungsi Pertunjukan Jathilan Dalam Upacara Ritual Kirab Pusaka Pada Masyarakat Kampung Tidar Magelang. Skripsi. Universitas Negeri Semarang

Jazuli, M. 1994. Telaah teoritis Seni Tari. Semarang: IKIP Semarang Press 
Jazuli, M. 2001. Paradigma Seni Pertunjukan. Yogyakarta: Yayasan Lentera

Jazuli, M. 2007. Pendidikan Seni Budaya. Suplemen Pembelajaran Tari. Semarang: UNNES PRESS

Ambarwangi, S., \& Suharto, S. (2014). REOG AS MEANS OF STUDENTS' APPRECIATION AND CREATION IN ARTS AND CULTURE BASED ON THE LOCAL WISDOM. Harmonia: Journal Of Arts Research And Education, 14(1), 37-45. doi:http://dx.doi.org/10.15294/harmonia.v14i1.2789

Suharto, S., \& Aesijah, S. (2014). THE LESUNG MUSIC IN THE VILLAGE OF LEDOK BLORA REGENCY. Harmonia: Journal Of Arts Research And Education, 14(1), 65-71. doi:http://dx.doi.org/10.15294/harmonia.v14i1.2851

Putra, B. (2013). PENGEMBANGAN MODEL KONSERVASI KESENIAN LOKAL SEBAGAI KEMASAN SENI WISATA DI KABUPATEN SEMARANG. Harmonia: Journal Of Arts Research And Education, 12(2). doi:http://dx.doi.org/10.15294/harmonia.v12i2.2525

Irianto, A. (2016). The Development of Jathilan Performance as an Adaptive Strategy Used by Javanese Farmers. Harmonia: Journal Of Arts Research And Education, 16(1), 38-48. doi:http://dx.doi.org/10.15294/harmonia.v16i1.5213

Hapsari, L. (2014). FUNGSI TOPENG IRENG DI KURAHAN KABUPATEN MAGELANG. Harmonia: Journal Of Arts Research And Education, 13(2). doi:http://dx.doi.org/10.15294/harmonia.v13i2.2780

Budiarti, M. (2011). MENGUBAHÂ CITRA LENGGER MENJADIÂ MEDIA EKSPRESIÂ ESTETIS (To Change the Image of Lengger Into Esthetic $\hat{A}$ Medium of Expression). Harmonia: Journal Of Arts Research And Education, 4(2). doi:http://dx.doi.org/10.15294/harmonia.v4i2.708

Darmasti. "TARI SESAJI PANGENTAS BILAHI SUDRA TINGAL." Harmonia: Journal of Arts Research and Education [Online], 12.2 (2012): n. pag. Web. 24 Sep. 2017

Close

KBBI.1995. Kamus Besar Bahasa Indonesia. Edisi ke-2. Jakarta: Balai Pustaka 
Khayam. 1981. Seni Tradisional Masyarakat. Jakarta: Balai Pustaka

Koentjaraningrat. 1984. Kebudayaan Jawa, Seri 2. Jakarta: Balai Pustaka

Koentjaraningrat. 2000. Kebudayaan Mentalitas dan Pembangunan (cetakan ke sembilan belas). Jakarta: PT. Gramedia Pustaka Utama

Kussudiardja, Bagong. 2000. Dari Klasik Hingga Kontemporer. Bantul: Padepokan Press

Lahiya. 2016. Pengertian Kebudayaan Definisi Menurut Para Ahli. Diunduh di http://www.lahiya.com/pengertian-kebudayaan-definisi-menurut-paraahli.html. Diunduh 22 Agustus 2016 pkl 09.21

Moleong, Lexy. 2001. Metode Penelitian Kualitatif. Bandung: PT. Remaja Rosdakarya

Muhtar. 2010. Bentuk dan Fungsi Pertunjukan Musik Kasidah Modern "Eliksada" di Desa Getas Kecamatan Singorojo Kabupaten Kendal. Skripsi.Universitas Negeri Semarang

Murgiyanto, Sal. 1983. Koreografi Pengetahuan Dasar Komposisi Tari. Depdikbud

Murgiyanto, Sal. 1986. Seni Menata Tari (The Art Making Dance). Jakarta: Dewan Kesenian Jakarta

Peter, Salim. 1991. Kamus Besar Bahasa Indonesia. Jakarta: Balai Pustaka

Rizqillah. 2015. Barongku Barong Kudus. Diunduh di http://sastradududewo.blogspot.co.id/2015/01/barongku-barongkudus.html. Diunduh 22 Agustus 2016 pkl 06.28

Sajid, Fahmi. 2015. Seni Budaya. Unsur-unsur Pergelaran Teater. Diunduh di http://sma-senibudaya.blogspot.com/2015/03/unsur-unsur-pergelaranteater.html tanggal 27 Maret 2015. Diunduh 22 Agustus 2016 pkl 07.49 
Shomayya.2009. Kesenian Di Kota Kudus. Diunduh di http://shomayyaman2kudus.blogspot.co.id/2009/08/kesenian-di-kota-

kudus.htmltanggal21Agustus2009. Diunduh 22 Agustus 2016 pkl 08.11

Soedarsono. 1977. Tarian-tarian Indonesia I. Proyek Pembangunan Media Kebudayaan Departemen Pendidikan dan Kebudayaan

Soedarsono. 1978. Tari-tarian Indonesia I. Jakarta: Balai Pustaka

Sugiyono. 2004. Metode Penelitian Administrasi. Bandung: Alfabeta

Sugiyono. 2008. Metode Penelitian Kualitatif (Kualitatif dan R\&O). Bandung: Alfabeta

Sumardjo, Jakob. 2000. Filsafat Seni. Bandung: ITB

Sumaryanto, Totok. 2007. Pendekatan Kuantitatif dan Kualitatif dalam Penelitian Pendidikan Seni. Semarang. UniversitasNegeri Semarang

SyahSinaga, Syahrul. 2001. Akulturasi Kesenian Rebana. Semarang Harmonia Vol. 2 No. 3/September-Desember. Semarang: UNNES

Utami, Sri. 2001. Bentuk Penyajian dan Usaha Pengembangan Seni Barong Sekar Joyo Kelurahan Kunden Blora. Skripsi. Universitas Negeri Semarang 
LAMPIRAN 


\section{SK PEMBIMBING}

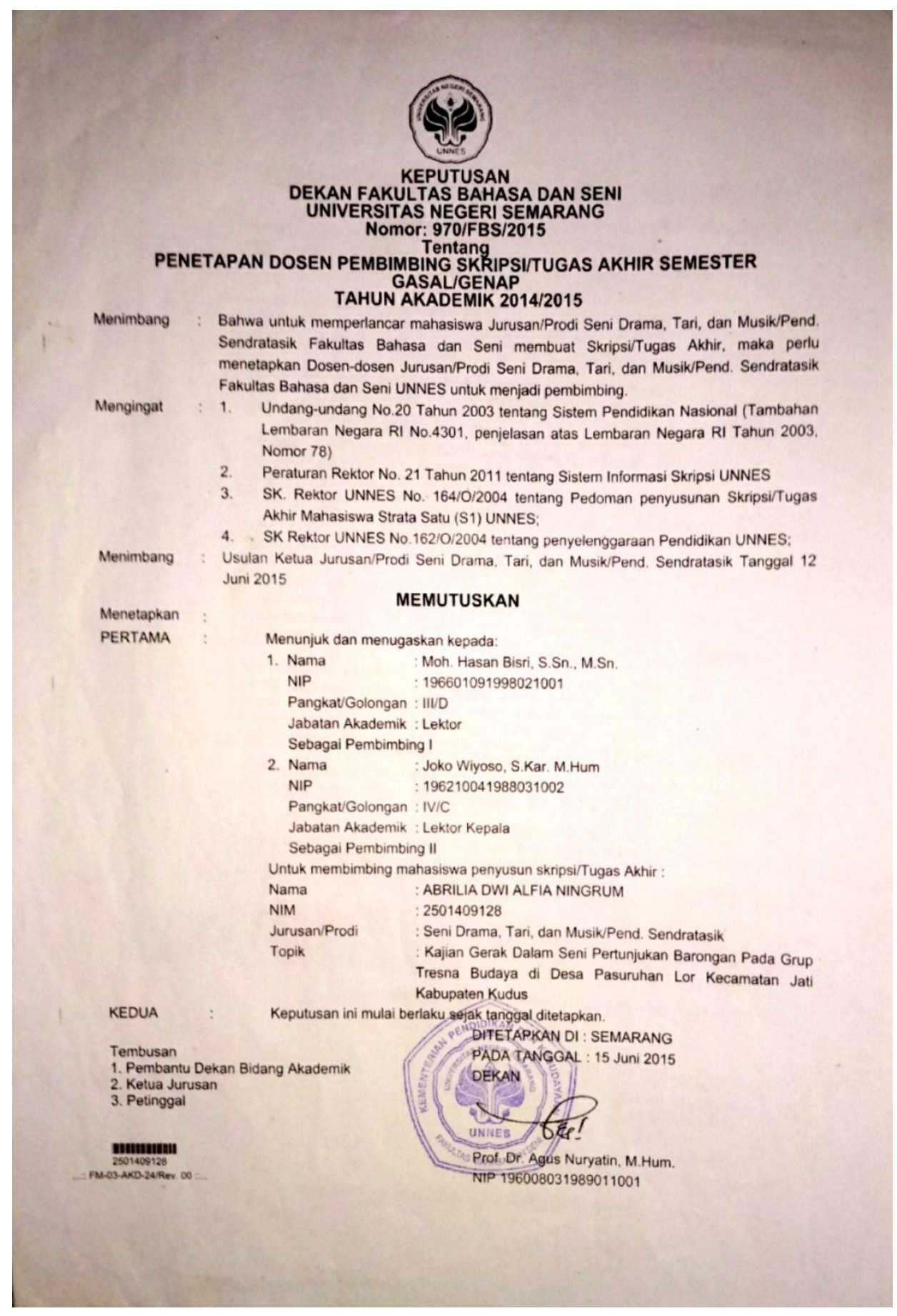




\section{SURAT IZIN PENELITIAN}

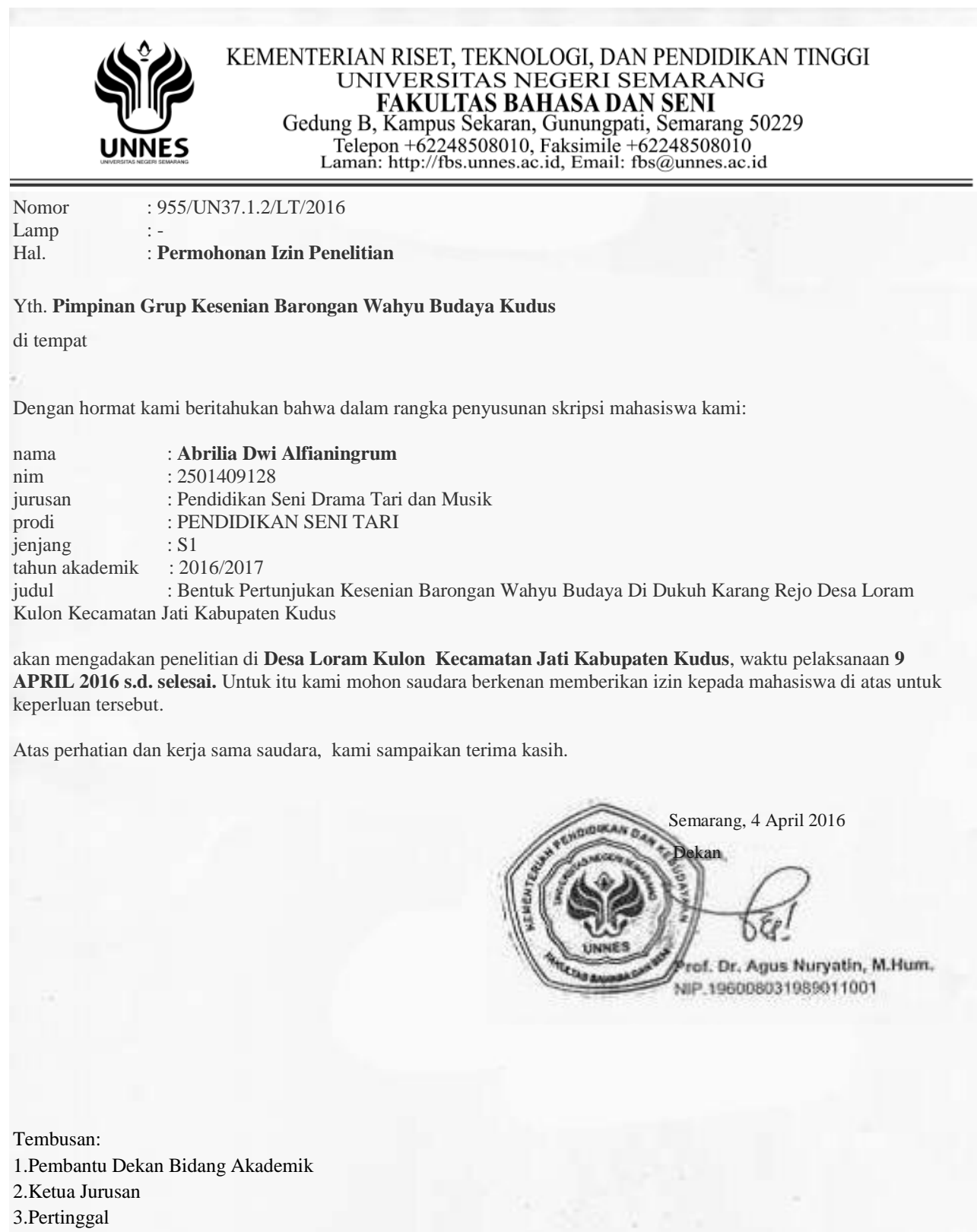

FM-05-AKD-24 


\section{SURAT KETERANGAN TELAH PENELITIAN}

\section{SURAT PERNYATAAN}

Yang bertanda tangan di bawah ini :

Nama : Nanang Bagus Sukadi

Alamat : Dukuh Karang Rejo RT 02 RW 03 Loram Kulon Kec. Jati Kab. Kudus

Jabatan : Ketua Grup Kesenian Barongan Wahyu Budaya Loram Kulon

Dengan ini menerangkan :

Nama : Abrilia Dwi Alfianingrum

NIM : 2501409128

Prodi : Pendidikan Seni Tari S1 UNNES

Telah melakukan penelitian di Desa Loram pada Grup Keseian Barongan Wahyu Budaya Kudus dalam rangka penelitian skripsi yang berjudul "Bentuk Pertunjukan Keseian Barongan Wahyu Budaya Di Dukuh Karang Rejo Desa Loram Kulon Kecamatan Jati Kabupaten Kudus”.

Demikian surat keterangan ini saya buat dengan sebenar-benarnya dan dipergunakan sebagaimana mestinya.

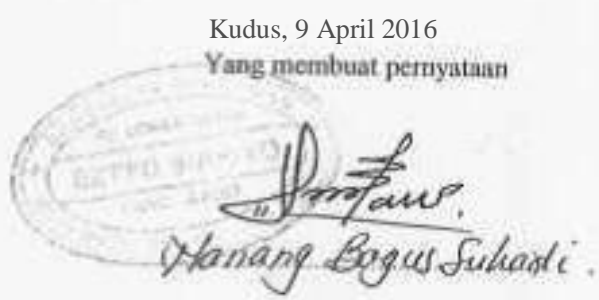




\section{INSTRUMEN PENELITIAN}

\section{A. Pedoman Observasi}

Pengamatan dalam penelitian meliputi:

1. Lokasi penelitian kebudayaan

2. Gambaran umum keadaan lokasi penelitian kebudayaan

3. Tempat pementasan

4. Sistem sosial dan kependudukan masyarakat tempat penelitian kebudayaan dilakukan

5. Mata pencaharian masyarakat di lokasi penelitian kebudayaan

6. Potensi kesenian di lokasi penelitian kebudayaan

7. Bentuk pertunjukan Kesenian Barongan Wahyu Budaya

\section{B. Pedoman Wawancara}

\section{Wawancara dengan ketua Grup Kesenian Barongan Wahyu Budaya}

1.1 Bagaimana sejarah terbentuknya Grup Kesenian Barongan Wahyu Budaya?

1.2 Bagaimana isi cerita kesenian Barongan?

1.3 Bagaimana bentuk Barongan Wahyu Budaya?

1.4 Bagaimana tahapan penyajian dari pertunjukan Barongan Wahyu Budaya?

1.5 Siapa saja yang dapat memainkan Barongan?

1.6 Berfungsi sebagai apa kesenian Barongan ditampilkan?

1.7 Seperti apa antusias warga terhadap kesenian Barongan Wahyu Budaya?

1.8 Waktu pelaksanaan pertunjukan

1.9 Termasuk jenis tarian apa Barongan Wahyu Budaya?

1.10 Berapa jumlah pemain?

1.11 Mengapa dinamakan Barongan Wahyu Budaya?

\section{Wawancara dengan Pembarong dan Pawang Barongan Wahyu Budaya}

2.1 Bagaimana asal usul kesenian Barongan berkembang di Kota Kudus?

2.2 Bagaimana isi cerita kesenian Barongan?

2.3 Sesaji apa saja yang dibutuhkan untuk persembahan sebelum pertunjukan? 
2.4 Doa apa yang dipanjatkan sebelum memulai acara?

2.5 Seperti apa peran pawang pada Kesenian Barongan Wahyu Budaya

2.6 Ragam gerak apa saja yang ditarikan oleh pawang?

2.7 Ragam gerak apa saja yang ditarikan oleh pemain Barong?

2.8 Peran apa saja yang dipakai dalam pertunjukan kesenian Barongan Wahyu Budaya?

2.9 Rias seperti apa yang dipakai?

2.10 Busana seperti apa yang dipakai?

2.11 Properti apa saja yang dibutuhkan?

2.12 Bagaimana urutan penyajian kesenian Barongan?

2.13 Bagaimana tanggapan warga dengan adanya kesenian Barongan?

2.14 Seperti apa keterlibatan masyarakat terhadap pertunjukan kesenian Barongan?

2.15 Fungsi apa yang diharapkan masyarakat sebagai penanggap Barongan?

2.16 Potensi kesenian apa saja yang dimiliki Desa Loram Kulon?

2.17 Apa yang diketahui oleh penonton tentang kesenian Barongan?

2.18 Apakah penonton memahami makna dari pertunjukan kesenian Barongan?

\section{Wawancara dengan Pemusik}

3.1 Alat musik apa saja yang digunakan untuk mengiringi kesenian Barongan Wahyu Budaya?

3.2 Bagaimana cara memainkan alat musik pendukung? 


\section{DATA INFORMAN}

\begin{tabular}{|c|c|}
\hline Nama & : Sukadi \\
\hline Umur & : 52 tahun \\
\hline Alamat & : Dukuh Karang Rejo, Loram Kulon \\
\hline Pekerjaan & : Wiraswasta, seniman \\
\hline Kedudukan & : Ketua Grup Ketoprak dan Barongan Wahyu Budaya \\
\hline Nama & : Karmin \\
\hline Umur & : 59 tahun \\
\hline Alamat & : Desa Wergu Wetan, Kecamatan Kota \\
\hline Pekerjaan & : Seniman \\
\hline Kedudukan & : Pawang Barong \\
\hline Nama & : Eko Wahyudi \\
\hline Umur & $: 21$ tahun \\
\hline Alamat & : Dukuh Karang Rejo, Loram Kulon \\
\hline Pekerjaan & : Seniman \\
\hline Kedudukan & : Pembarong \\
\hline Nama & : Sumaryono \\
\hline Umur & : 55 tahun \\
\hline
\end{tabular}




$\begin{array}{ll}\text { Alamat } & \text { : Dukuh Karang Rejo, Loram Kulon } \\ \text { Pekerjaan } & \text { : Buruh Pabrik } \\ \text { Kedudukan } & \text { : Warga Dukuh Karang Rejo, Loram Kulon } \\ \text { Nama } & \text { : Suprianto } \\ \text { Umur } & \text { : } 38 \text { tahun } \\ \text { Alamat } & \text { : Desa Peganjaran Kecamatan Bae } \\ \text { Pekerjaan } & \text { : Satpam Pabrik } \\ \text { Kedudukan } & \text { : Warga asli Desa Loram Kulon }\end{array}$

